\title{
Public Perceptions of Insider Trading
}

\author{
John P. Anderson, ${ }^{*}$ Jeremy L. Kidd ${ }^{* *} \&$ George A. Mocsary ${ }^{* *}$
}

The U.S. insider trading enforcement regime has been mired in controversy since the SEC introduced it in 1961. Some have argued that the SEC should not regulate insider trading because it improves market performance. Others have argued that the SEC must vigorously regulate insider trading because it is unfair and undermines market confidence. Arguments on both sides of this debate, however, rest on empirical claims that are rarely backed by data. The resulting impasse has left lawmakers and jurists without a clear sense of what conduct they should proscribe and why. This, in turn, has placed market participants in a state of confusion that has been exaggerated by insider trading's being a common law offense, never having been defined by statute or rule. But after sixty years, Congress appears poised to act. With reform proposals pending, reliable empirical evidence of public attitudes concerning insider trading has never been more needed. This Article presents the results of the first large-scale national survey of public attitudes regarding insider trading since 1986, and the first comprehensive, census-representative study ever conducted on the subject. It offers valuable data to inform claims regarding public perceptions of, inter alia, the fairness of different forms of insider trading, its pervasiveness, and the public's willingness to participate in markets where insider trading is common.

*J. Will Young Professor of Law, Mississippi College School of Law. University of Virginia School of Law, J.D. University of Virginia, Ph.D. (Philosophy).

**Associate Professor, Mercer University School of Law. Antonin Scalia Law School at George Mason University, J.D. Utah State University Huntsman School of Business, Ph.D. (Economics).

***Professor of Law, University of Wyoming College of Law. Fordham University School of Law, J.D., summa cum laude, 2009; University of Rochester Simon School of Business, M.B.A., 1997. We thank Miriam Baer, William Baude, Joseph Blocher, Kevin Douglas, Jennifer Fuller Flath, Sean Griffith, Nicholas J. Johnson, Matthew B. Kugler, and Lior Strahilevitz for their invaluable comments. We are grateful to Jacob Beckett, Tosha Childs, Nathan Cowper, Najla Hasic, Jessica Hostert, and Teris Swanson for their excellent research. This Article is dedicated to Jessica Hostert, who passed away before she could see the results of her work in print. 
I. INTRODUCTION 1037

II. THE STATE OF INSIDER TRADING LAW AND SCHOLARSHIP ......................... 1040

A. Historical Development................................................................. 1040

1. The Common Law Era ......................................................... 1040

2. Federal Regulation and the Modern Era........................... 1041

3. The Supreme Court Weighs In ......................................... 1044

4. Twenty-First Century Developments and Unresolved Questions 1051

B. Challenges and Controversies..................................................... 1053

1. The Harmful Consequences of Ambiguity in the Law and Call for Reform 1053

2. Ongoing Debate over the Economics and Ethics of Insider Trading 1056

3. Market Confidence, Fairness, and the Importance of Empirical Evidence of Public Attitudes to Reform Efforts 1058

III. THE SURVEY INSTRUMENT 1059

A. Survey Strategy 1060

B. Survey Design and Administration 1064

1. Stage 1: Direct Assessment of Insider Trading Views 1065

2. Stage 2: Scenario-Based Assessment of Insider Trading Views. 1066

C. Limitations 1070

1. Sampling Error 1070

2. Respondent Background Knowledge 1070

3. Respondent Understanding and Question Interpretation 1072

4. Results Interpretation 1073

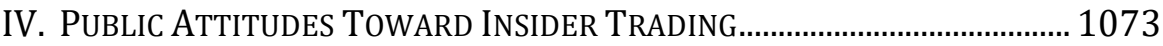

A. Comparisons to 1986 ……………………………………………... 1075

B. Pervasiveness. 1075

C. Market Confidence................................................................................. 1077

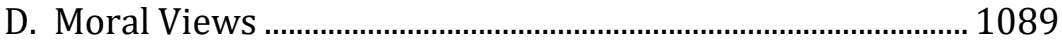

1. Stated Moral Positions............................................................ 1090

2. Revealed Moral Positions......................................................... 1093

i. Morality via Pragmatism .................................................. 1093

ii. Morality via Legality............................................................ 1096

3. Self-Conscious Punishment Views...................................... 1098

E. Fiduciary Instincts and Propaganda .........................................1103

1. Revealed Fiduciary Views..................................................... 1104

i. Ethical Track. 1104

ii. Pragmatic Track. 1108

2. Propaganda is Effective 


\section{INTRODUCTION}

In October of 2018, Securities and Exchange Commissioner Robert Jackson, and former United States Attorney Preet Bharara, announced the creation of a task force to propose reforms to America's "shoddy," "unclear," and "confused" insider trading laws. ${ }^{1}$ Jackson and Bharara's concerns are not isolated. As Professor Peter Henning noted, leading jurists regularly criticize the U.S. insider trading regime as being "a 'theoretical mess,' 'seriously flawed,' 'extraordinarily vague and ill-formed,' 'arbitrary and incomplete,' a 'scandal,' and even 'astonishingly dysfunctional.'”2

Much of the frustration stems from neither statute nor regulation ever defining "insider trading." ${ }^{3}$ Congress and the Securities and Exchange Commission (SEC) have allowed the law to develop in the courts and administrative tribunals. ${ }^{4}$ But without the benefit of clear legislative guidance, the area's sixty years of common law development has been neither linear in direction nor consistent in outcome. ${ }^{5}$ As a result, insider trading law "has suffered-and continues to suffer-from uncertainty and ambiguity to a degree not seen in other areas of the law."6

For the first time in U.S. insider trading law's sixty-year history, broad-based momentum is building for comprehensive statutory reform. ${ }^{7}$ Congress recently introduced three comprehensive reform bills, each proposing a different statutory definition of "insider

1 Preet Bharara \& Robert Jackson, Insider Trading Laws Haven't Kept Up with the Crooks, N.Y. Times, Oct. 9, 2018, https://www.nytimes.com/2018/10/09/opinion/secinsider-trading-united-states.html.

2 Peter J. Henning, What's So Bad About Insider Trading Law?, 70 Bus. Law. 751, 751 (2015) (footnotes omitted).

3 Stephen M. Bainbridge, Securities LaW: InSider Trading 26-27 (2d ed. 2007).

4 Id. at 28-29.

5 See infra Part II.

6 Preet Bharara et Al., Report of the Bharara Task Force 1 (2020).

7 Congress passed two insider trading laws in the 1980s, the Insider Trading Sanctions Act of 1984 and the Insider Trading and Securities Fraud Enforcement Act of 1988. Insider Trading Sanctions Act of 1984, Pub. L. No. 98-376, 98 Stat. 1264 (codified as amended in scattered sections of 15 U.S.C.); Insider Trading and Securities Fraud Enforcement Act of 1988, Pub. L. No. 100-704, 102 Stat. 4677 [hereinafter ITSFEA] (codified as amended in scattered sections of 15 U.S.C.). Although these statutes enhanced fines and penalties, neither defined "insider trading." 
trading."8 In December 2019, one of these bills, the Insider Trading Prohibition Act, passed the House with a near-unanimous 410-13 vote. ${ }^{9}$ In January 2020, the Bharara Task Force on Insider Trading issued a Report recommending comprehensive statutory reform similar in many respects to that passed by the House. ${ }^{10}$

Reform should be deliberate and informed, lest the opportunity for comprehensive improvement be squandered. After sixty years of controversy and inconsistency, Congress should implement a fair and efficient insider trading regime. To the extent that it would impose criminal penalties, as it almost certainly would, it is particularly important that the reformers be clear about both the moral and economic harms the law strives to guard against alongside the good it seeks to promote.

Congress would be remiss to engage in a statutory overhaul without considering the public's attitudes concerning such conduct. Reformers repeatedly assert, as the principal justification for regulating insider trading, that the practice leads the public to "question the fundamental fairness and integrity of the markets."11 But neither Congress nor the Bharara Task Force appear to have informed their proposed reforms with empirical evidence of what the public actually thinks of insider trading. ${ }^{12}$ Does the average American think that it is unfair to trade based on material nonpublic information? If so, under what circumstances? Would the average American be less willing to participate in markets if he or she knew that insider trading was prevalent? Given the persistent debate over the ethics and economics of insider trading, ${ }^{13}$ it would be irresponsible simply to assume the answers to these questions.

This Article looks to correct this empirical lacuna by presenting the results of the first large-scale national survey of public attitudes regarding insider trading since 1986, and the first comprehensive, census-representative study conducted on the topic. ${ }^{14}$ It offers a

8 See Stop Illegal Insider Trading Act, S. 702, 114th Cong. (2015); Ban Insider Trading Act, H.R. 1173, 114th Cong. (2015); Insider Trading Prohibition Act, H.R. 1625, 114th Cong. (2015).

9 H.R. 2534, 116th Cong. (2019).

10 BHARARA ET AL., supra note 6, at 4.

11 Id.

12 The Report of the Bharaha Task Force, for example, offers no external support for its claim that " $[\mathrm{m}]$ ost agree that there is something fundamentally unfair about [insider trading]." BHARARA ET AL., supra note 6, at 3. Indeed, the report offers no evidence of public attitudes concerning insider trading. See generally id.

13 See infra Sections III.D-E.

14 Perhaps the most frequently cited studies of public attitudes regarding insider trading are the pair of 1986 Business Week/Harris polls taken before and after the Ivan 
detailed attitudinal assessment of public views about insider trading's morality and legality (or lack thereof), as well as its effect on the public's willingness to participate in equity markets. The study breaks down its results by U.S. Census categories according to age, income, education, race, and political ideology.

The results reflect some ambivalent attitudes concerning the ethics and harms associated with insider trading. They raise several important questions. For example, what does it mean that nearly a fifth of respondents would engage in insider trading even though they believe it to be immoral? But this Article's goal is not to draw strong conclusions from the survey's results. Instead, this Article presents the results in a manner that is useful to jurists, scholars, regulators, and legislators as they work to effect statutory reform. To date, proponents of reform have speculated about what the public deems "fair" and "unfair." 15 They have assumed the impact of insider trading on market "integrity." 16 This survey's results thus inform the public discourse using timely data.

This Article proceeds as follows: Part II offers a brief history of insider trading law's common law development and identifies some of the legal and theoretical issues that have motivated current reform

Boesky insider trading scandal. Business Week/Harris Poll: Outsiders Aren't Upset by Insider Trading, Bus. WK., Dec. 8, 1986, at 34 [hereinafter Business Week 12/86]; Business Week/Harris Poll: Insider Trading Isn't a Scandal, Bus. WK., Aug. 25, 1986, at 74 [hereinafter Business Week 8/86]. Two more recent studies were published in 2011. Stuart P. Green \& Mathew B. Kugler, When Is It Wrong to Trade Stocks on the Basis of Non-Public Information?: Public Views of the Morality of Insider Trading, 39 FordHAM URB. L.J. 445 (2011); Meir Statman, Is it Fair?: Perceptions of Fair Investment Behavior Across Countries, 12 BehaV. Fin. 47 (2011). Professor Statman conducted a "convenience study," a preliminary, nonprobability analysis of student views on the subject. Id. Professors Green and Kugler conducted a more sophisticated, but still exploratory, trio of studies using Amazon Mechanical Turk, https://www.mturk.com, to investigate American opinions. Green \& Kugler, supra, at 461 . Although neither constitutes a fully scientific survey, both were extremely helpful, and the current survey owes much of its design to Green \& Kugler. A 1961 Harvard Business Review article described a study in which executives were asked whether they would trade on information learned at a board meeting. Raymond C. Baumhart, How Ethical Are Businessmen?, Harv. Bus. Rev., July-Aug. 1961, at 6-7.

15 See BHARARA ET AL., supra note 6.

16 Id. passim; see also United States v. O’Hagan, 521 U.S. 642, 658 (1997) ("[I]nvestors likely would hesitate to venture their capital in a market where [insider trading] is unchecked by law."). Courts, regulators, and scholars often use "market confidence," "market integrity," and "investor confidence" interchangeably. E.g., BHARARA ET AL., supra note 6 (using the term "integrity of our securities markets" to refer to what others may call "market confidence"); James J. Park, Rule 10B-5 and the Rise of the Unjust Enrichment Principle, 60 DuKE L.J. 345, 362-63 (2010). This Article's reference to the "market-confidence theory" of justification for regulating insider trading applies equally to claims concerning the impact of insider trading on "market integrity." 
efforts. This Part concludes by outlining the principal goals of this study in light of current reform efforts. Those familiar with insider trading law's historical development and controversies may wish to turn directly to Part III, which describes the survey's approach, methods, and limitations. Part IV presents results and offers some preliminary explanations. Part V outlines future studies contemplated by the Authors to supplement and complement this survey's results.

\section{THE STATE OF INSIDER TRADING LAW AND SCHOLARSHIP}

From its inception in the early 1960s, the insider trading enforcement regime in the United States-the first in the world-has been fraught with controversy, instability, and uncertainty.

\section{A. Historical Development}

\section{The Common Law Era}

Before 1961, insider trading as it is understood today did not incur criminal or civil liability in any nation. ${ }^{17}$ In the United States, state common law of insider trading was divided.18 The majority of jurisdictions did not recognize a broad fiduciary duty of loyalty between board members or executive officers and individual shareholders in the context of stock trading. ${ }^{19}$ Courts did hold that "special facts" (e.g., evidence of affirmative misrepresentations or concealment) might give rise to an equitable duty for board members or senior management to disclose information advantages in advance of trading with shareholders, but not when trading over anonymous exchanges. ${ }^{20}$ By the early twentieth century, a minority of jurisdictions began recognizing a broad duty of loyalty among board members and senior management to disclose material nonpublic information to shareholder-counterparties in arm's-length stock transactions in their

17 See, e.g., John P. ANDERSON, Insider TRAding: LAW, ETHICS, AND REForm 132-33 (2018); Utpal Bhattacharya \& Hazem Daouk, The World Price of Insider Trading, 57 J. Fin. 75, 89-90 (2002).

18 See Stephen M. Bainbridge, Insider Trading LaW and Policy 11-13 (2014).

19 See, e.g., Anderson, supra note 17, at 23; see also Carpenter v. Danforth, 52 Barb. 581 (N.Y. Sup. Ct. 1868); Bd. of Comm'rs of Tippecanoe Cnty. v. Reynolds, 44 Ind. 509 (1873).

20 See, e.g., Goodwinn v. Agassiz, 186 N.E. 659, 661-62 (Mass. 1933) (holding insiders have no fiduciary duty to disclose when trading over impersonal exchanges); Strong v. Repide, 213 U.S. 419, 431 (1909) (holding that board members and officers may have a duty to disclose before trading with shareholders upon a showing of "special facts"). 
firm's shares, ${ }^{21}$ but it remained entirely unclear whether even these courts would extend this duty to transactions over anonymous exchanges. ${ }^{22}$

Before 1961, no state court had recognized a disclose-or-abstainfrom-trading rule for low-level insiders trading on their company's material nonpublic information. ${ }^{23}$ Moreover, all the early state-law cases addressed the problem of insider trading as a matter of contract law or unjust enrichment. ${ }^{24}$ No states imposed civil fines or criminal liability for insider trading prior to the advent of the modern federal enforcement regime. ${ }^{25}$

\section{Federal Regulation and the Modern Era}

Beginning in 1961, SEC Commissioner William Carey, a former Columbia law professor, made it something of a personal mission to introduce "insider trading" into the American lexicon of civil and criminal liability. ${ }^{26}$ Carey, however, confronted a significant obstacle. The SEC's rulemaking enforcement power was limited by its statutory authority, and no statute expressly bars trading in securities on the basis of material nonpublic information. Section 16 of the Securities Exchange Act of 1934 ('34 Act) proscribed short-swing trading by certain statutorily-identified insiders but was very limited in scope. ${ }^{27}$ Further, only the issuer or its shareholders could bring an action under

21 See, e.g., Oliver v. Oliver, 45 S.E. 232 (Ga. 1903); Stewart v. Harris, 77 P. 277 (Kan. 1904); Hotchkiss v. Fischer, 16 P.2d 531 (Kan. 1932).

22 See BAINBRIDGE, supra note 18, at 13-16.

23 ANDERSON, supra note 17, at 24.

24 Id.

25 Id.

26 See, e.g., Kurt A. Hohenstein, Fair to All People: The SEC and the Regulation of Insider Trading: The SEC Takes Command, SEC HIST. SoC'Y, http://www.sechistorical.org/ museum/galleries/it/takeCommand_a.php (last visited Jan. 10, 2020). Carey's personal devotion to this principal may have blinded him to the potential for chaos in the regime he crafted. Current reform efforts should avoid this pitfall and be based on broad public sentiment, not the preferences of any individual.

27 See 15 U.S.C. $\$ 78 p(b)$. Section 16(b) imposes only limited restrictions on a limited number of statutorily defined insiders' ("directors," "officers," and "principal stockholders") ability to trade. 15 U.S.C. § 78p. Its trading restrictions are also quite limited. It provides that any profits earned by these insiders from a purchase and sale (or a sale and purchase) of their company's shares that occurs within a period of less than six months are recoverable by the issuer-regardless of whether the insider traded bases on material nonpublic information. 15 U.S.C. $§ 78 p(b)$. Section 16(c) also makes it unlawful for these insiders to sell their company's shares short. 15 U.S.C. 78p(c). It does nothing to restrict trading by insiders who possess material nonpublic information, but are not "directors," "officers," or "principal shareholders." Even statutorily defined insiders are not precluded from trading based on their firms' material nonpublic information if their trading does not fall within the short-swing period. 
the statute, and it could not form the basis of a federal civil or criminal enforcement action.28 Undeterred, Carey and the SEC began bringing insider trading actions under the '34 Act's general anti-fraud provision in Section 10(b).

Section 10(b), implemented as Exchange Act Rule 10b-5,29 prohibits the employment of "any manipulative or deceptive device or contrivance" in "connection with the purchase or sale of any security." 30 Carey brought an insider trading action under Section 10(b), for the first time since the sections' 1934 enactment, in In the Matter of Cady, Roberts \& Company. ${ }^{31}$ He wrote Cady, Roberts himself, and because the case was settled, his opinion was subject to neither adversarial fact testing nor judicial review. ${ }^{32}$ Cady, Roberts introduced the violation of insider trading by interpreting Rule 10b-5 broadly "to encompass the infinite variety of devices by which undue advantage may be taken of investors." 33 With the stage thus set, Carey offered the first articulation of the "disclose-or-abstain rule" whereby persons

must disclose material facts which are known to them by virtue of their position but which are not known to persons with whom they deal and which, if known, would affect their investment judgment. Failure to make disclosure in these circumstances constitutes a violation of the anti-fraud provisions. If, on the other hand, disclosure is prior to effecting a purchase or sale would be improper or unrealistic under the circumstances, we believe the alternative is to forego the transaction. ${ }^{34}$

Chairman Carey explained that this broad duty to disclose or abstain from trading was justified as deriving, first, from the "existence of a relationship giving access, directly or indirectly, to information intended to be available only for a corporate purpose and not for the personal benefit of anyone, and second," due to "the inherent unfairness involved where a party takes advantage of such information knowing it is unavailable to those with whom he is dealing." 35 These words were controversial from the start.

2815 U.S.C. § 78p; see also BAINBRIDGE, supra note 18, at 226.

2917 C.F.R. $\$ 240.10 b-5$.

3015 U.S.C. $\$ 78 \mathrm{j}(\mathrm{b})$.

3140 S.E.C. 907 (1961).

32 ANDERSON, supra note 17, at 33 n.30.

33 In re Cady, Roberts \& Co. 40 S.E.C. 907, 911 (1961).

34 Id.

35 Id. at 912. 
Concerning Carey's first justification for the broad disclose-orabstain rule, as noted above, state common law had never recognized so broad a duty for insiders trading in their own companies' shares. ${ }^{36}$ Concerning the second justification, it is not obvious that trading on an information advantage is "inherently unfair," even when the information is not immediately accessible to the counterparty. ${ }^{37}$ Philosophers, economists, and jurists have debated this question for millennia without clear resolution. ${ }^{38}$ Indeed, for two hundred years, courts have cited Chief Justice Marshall's decision in Laidlaw v. Organ for the proposition that, absent evidence of affirmative fraud, a contracting party is not typically required to disclose even a material information advantage to a counterparty. ${ }^{39}$

In addition to controversy over Carey's moral justification for the broad disclose-or-abstain rule outlined in Cady, Roberts, economists immediately challenged the rule's economic justification. Among the '34 Act's principal purposes is the promotion of the efficiency, transparency, and accuracy of markets. ${ }^{40}$ But Henry Manne famously argued that insider trading actually promotes market efficiency and transparency. ${ }_{41}$ Others have challenged this view, but one side has yet to convince the other. 42

In sum, the U.S. insider trading enforcement regime was introduced in 1961 as the brainchild of a former law professor and newly appointed SEC Chairman. It lacked statutory definition and clear historical or common law precedent. Its moral and market-based

36 See supra Section II.A.

37 ANDERSON, supra note 17, at 143-60.

38 See, e.g., CICERO, DE OFFICIIS 321 (Walter Miller, trans., 1913) (outlining Stoic philosophers' contrasting views on the ethics of trading based on information asymmetries); see also Anthony T. Kronman, Mistake, Disclosure, Information, and the Law of Contracts, 7 J.L. STUD. 1 (1978) (arguing that a party's ability to trade based on an information advantage should turn on whether the information was acquired deliberately or casually); Randy Barnett, Rational Bargaining Theory and Contract Default Rules, Hypothetical Consent, the Duty to Disclose, and Fraud, 15 HARV. J.L. \& PuB. POL'y 783, 796 (1992) (suggesting that sometimes a party suffering from an information disadvantage in a proposed transaction does not have the right to ask for more information); Saul Levmore, Securities and Secrets: Insider Trading and the Law of Contracts, 68 VA. L. REV. 117, 140 (1982) (suggesting that some parties enjoying information advantages have a right to be dishonest in response to some inquiries in order to protect their advantages).

39 Laidlaw v. Organ, 15 U.S. 178 (1817).

40 See e.g., Will Kenton, Securities Exchange Act of 1934, InVESTOPEDIA, https://www.investopedia.com/terms/s/seact1934.asp (last updated Oct. 30, 2020) (noting that the '34 Act was created for the purpose of "ensuring greater financial transparency and accuracy and less fraud or manipulation").

41 See Henry Manne, Insider Trading and the Stock Market (1966).

42 See infra Section II.B.2. 
justifications were controversial from the beginning. But the regime took flight. It received the imprimatur of the federal courts in 1968 in SEC. v. Texas Gulf Sulphur Co., ${ }^{43}$ in which the Second Circuit gave the Cady, Roberts disclose-or-abstain rule its broadest expression. The court explained that the "only regulatory objective" for Rule 10b-5 "is that access to material information be enjoyed equally." 44 The court thus held that Cady, Roberts's duty to disclose or abstain should place all traders on an "equal footing," and therefore applies to "anyone in possession of material inside information," without regard to insider status. 45

\section{The Supreme Court Weighs In}

Texas Gulf Sulphur's articulation of American insider trading law demanding equal access to (or even a parity of) information ${ }^{46}$ in securities transactions held sway until the U.S. Supreme Court addressed the issue in Chiarella v. United States in 1980.47 While working as a "mark-up" man for a financial printer, Vincent Chiarella decoded documents to discover the targets of tender offers before they were made public. ${ }^{48}$ He then profited from trading on this material nonpublic information. ${ }^{49}$ Because Chiarella's employer was hired by the purchasing companies, he was not an actual or constructive insider at the targets and, therefore, had no cognizable fiduciary or similar duty to the targets' shareholders. Consistent with Texas Gulf Sulphur, the Second Circuit held that Chiarella's status as an outsider was not crucial to his liability, holding that "[a]nyone-corporate insider or not-who regularly receives material nonpublic information may not use that information to trade in securities without incurring an affirmative duty

43 SEC. v. Texas Gulf Sulphur Co., 401 F.2d 833, 851 (2d Cir. 1968).

44 Id. at 849.

45 Id. at $848,851-52$.

46 An "equal-access" insider trading regime precludes trading by those who have acquired material nonpublic information via special access to sources that are structurally closed to other market participants (e.g., from an employer)-regardless of whether such trading breaches a fiduciary or similar duty of trust and confidence. ANDERSON, supra note 17, at 118. A "parity-of-information" regime precludes trading based on all material nonpublic information regardless of its source (e.g., picking up a draft earnings report that was misplaced on a bus). Id.

47445 U.S. 222 (1980). The Supreme Court addressed insider trading as a matter of federal common law in Strong. Strong v. Repide, 213 U.S. 419 (1909). The Court first addressed insider trading under the federal securities statutory regime in Chiarella.

48 Chiarella, 445 U.S. at 224.

49 Id. 
to disclose." 50 The Supreme Court reversed, expressly rejecting a "parity of information" or equal-access theory of liability. ${ }^{51}$

In an opinion authored by Justice Lewis Powell, Jr., the Chiarella Court held that while Section $10(\mathrm{~b})$ is "aptly described as a catchall provision ... what it catches must be fraud." 52 But because Chiarella made his trades over anonymous exchanges, he never made false representations to his counterparties. Such trading, Chiarella held, is fraudulent only if one party trades based on material nonpublic information that "the other [party] is entitled to know because of a fiduciary or other similar relation of trust and confidence between them." 53

The Court acknowledged common law support for the proposition that corporate insiders bear such a duty to disclose before trading with their shareholders, ${ }^{54}$ and therefore recognized what has since come to be known as the "classical theory" of insider trading liability. ${ }^{55}$ Under that theory, a corporate insider who trades in his or her own company's shares on the basis of material nonpublic information breaches a fiduciary or similar duty of trust and confidence to the current or prospective shareholder-counterparty. ${ }^{56}$

Because Chiarella was not an insider at the target corporations in whose shares he traded, he owed no such duty of disclosure to his counterparties. The trial court therefore erred by instructing the jury that Chiarella "owed a duty [of disclosure] to everyone; to all sellers, indeed, to the market as a whole." 57 The Court held that Texas Gulf Sulphur's parity-of-information rule "departs radically" from the fiduciary-fraud-based model demanded by fealty to Section 10(b) and "should not be undertaken absent some explicit evidence of congressional intent." 58 The Court instructed that permitting some

50 United States v. Chiarella, 588 F.2d 1358, 1365 (2d Cir. 1978) (emphasis in original).

51 Chiarella, 445 U.S. at 233.

52 Id. at 234-35.

53 Id. at 228 (alteration in original).

54 Id. at 227-28.

55 United States v. O'Hagan, 521 U.S. 642, 651-52 (1997) (noting that under "the 'traditional' or 'classical theory' of insider trading liability, § $10(\mathrm{~b})$ and Rule 10b-5 are violated when a corporate insider trades in the securities of his corporation on the basis of material, nonpublic information").

56 Chiarella, 445 U.S. at 230.

57 Id. at 231.

58 Id. at 233. Though the Court does not mention Texas Gulf Sulphur in connection with its rejection of the parity-of-information rule, the rule it rejects is the same as that which was laid out in that case, and which was relied upon by the Second Circuit in upholding Chiarella's conviction. For example, the Second Circuit decision noted that 
market participants to trade on insurmountable information advantages may be unfair, but "not every instance of financial unfairness constitutes fraudulent activity" under Section 10(b). ${ }^{59}$ The equal-access model for insider trading liability that had been advanced by the SEC and had reigned for nearly twenty years was dead.

Yet, no sooner had the Court killed the equal-access model than the SEC set to work reviving it (or at least its scope of liability) by rulemaking and more expansive interpretations of the law. Six months after Chiarella was handed down, the SEC adopted Exchange Act Rule 14e-3.60 This new rule imposed liability on anyone possessing "material information [that relates] to a tender offer [by another person,] which information he knows or has reason to know is nonpublic and... [was] acquired, directly or indirectly," from that person or the issuer of the securities that are targeted by the tender offer. ${ }^{61}$ Although limited to the tender-offer context, Rule $14 \mathrm{e}-3$ dispensed with the requirement that the trade be made in violation of a fiduciary or similar relationship, immediately expanding insider trading liability to capture Chiarella-type trading. ${ }^{62}$

The SEC also sought to push the limits of the classical theory of liability in the tipper-tippee context in Dirks v. SEC. ${ }^{63}$ In that case, Ronald Secrist, a former insider at a publicly-traded insurance company, shared material nonpublic information about an ongoing fraud taking place at his former employer with Raymond Dirks, a securities analyst. ${ }^{64}$ Secrist "urged Dirks to verify the fraud and disclose it publicly." 65 Although Dirks did not trade on this tip, a number of his clients whom he informed about the fraud sold out of their positions in the insurer.66 When the fraud came to light (largely due to Dirks's efforts), the insurer's stock

Chiarella "recognizes, moreover, that since SEC v. Texas Gulf Sulphur ... it has been Black letter law that 'anyone in possession of material inside information must either disclose it to the investing public, or ... must abstain from trading.'” United States v. Chiarella, 588 F.2d 1358, 1364 (2d Cir. 1978).

59 Chiarella, 445 U.S. at 232.

6017 C.F.R. $\$ 240.14 \mathrm{e}-3$. This rule was adopted pursuant to the SEC's authority under Sections 14(e) and 23(a) of the '34 Act. 15 U.S.C. $\S \S 78 \mathrm{n}(\mathrm{e}), 78 \mathrm{w}(\mathrm{a})$. Tender Offers, Exchange Act Release No. 17120, 20 S.E.C. Docket 1350 (Sept. 4, 1980), at*15 (noting that the "Commission hereby adopts rule 14e-3...pursuant to Sections 14(e) and 23(a) of the Exchange Act).

61 See generally id.

6217 C.F.R. § 240.14e-3.

63463 U.S. 646 (1983).

64 Id. at 648-49.

65 Id. at 649.

66 Id. 
price plummeted and the company entered receivership. ${ }^{67}$ The SEC promptly brought an enforcement action against Dirks for encouraging his clients to trade on Secrist's information. 68

The SEC's theory of Section 10(b) tippee liability was that " $[\mathrm{w}]$ here tippees-regardless of their motivation or occupation-come into possession of material 'corporate information that they know is confidential and know or should know came from a corporate insider,' they must either publicly disclose that information or refrain from trading." 69 The Supreme Court, Justice Powell again writing, rejected this theory as relying on the same logic that failed in Chiarella, reminding the SEC that Section 10(b) does not "require equal information among all traders." 70 The Court explained that "mere possession of nonpublic information does not give rise to a duty to disclose or abstain; only a specific [fiduciary-like] relationship does that."71 Indeed, as a matter of public policy, such a broad parity-ofinformation rule would risk damaging markets by impeding analysts in "ferret[ing] out and analyz[ing] information . . . by meeting with and questioning corporate officers and others who are insiders."72 To protect such beneficial information gathering, and consistent with Chiarella, the Court held that

a tippee assumes a fiduciary duty to the shareholders of a corporation not to trade on material nonpublic information only when the insider has breached his fiduciary duty to the shareholders by disclosing the information to the tippee and the tippee knows or should know that there has been a breach.73

An insider or tippee breaches this duty where the insider seeks to personally benefit from his or her disclosure to the tippee: "Absent some personal gain [by the tipper], there has been no breach of duty to stockholders. And absent a breach by the insider, there is no derivative breach" by the tippee. ${ }^{74}$ Because Secrist tipped Dirks only to expose an ongoing fraud (and not to benefit personally), he did not breach his fiduciary duty to the insurer's shareholders, so Dirks committed no

67 Id. at 650

68 Id. at 650-51.

69 Dirks, 463 U.S. at 651.

70 Id. at 656-57.

71 Id. at 656 n.15.

72 Id. at 658.

73 Id. at 660 .

74 Id. at 662 . 
derivative breach. ${ }^{75}$ The Supreme Court recently affirmed Dirks's personal-benefit test in Salman v. United States. ${ }^{76}$

Despite setbacks in Chiarella and Dirks, the SEC and prosecutors continued to press for broader Section 10(b) insider trading liability. In particular, the government started prosecuting market participants under a new fraud-based theory that would extend to corporate outsiders. In briefing Chiarella, prosecutors argued that Chiarella had "breached a duty to the acquiring corporation when he acted upon information that he obtained by virtue of his position as an employee of a printer employed by the corporation." 77 The Court rejected this theory as to Chiarella because it had not been presented to the jury, but did not rule on the merits ${ }^{78}$ of this "misappropriati[on]" theory of Section 10 (b) insider trading liability until it decided Carpenter v. United States. ${ }^{79}$

Carpenter involved well-known Wall Street Journal columnist R. Foster Winans, who regularly tipped the confidential pre-publication contents of his stock-picking column to friends who then traded on this information in advance of the article's release. ${ }^{80}$ The resulting trading profits (approximately $\$ 690,000$ ) were shared among the scheme's participants. $^{81}$ Because Winans owed no fiduciary duty to the shareholders of the stocks he picked in his column, he was not liable under the classical theory of insider trading. Prosecutors instead charged that Winans breached a fiduciary duty to the Wall Street Journal by misappropriating its confidential pre-publication information and that he did so "in connection with" the purchase or sale of securities because "the scheme's sole purpose was to buy and sell securities at a profit based on advance information of the column's contents." 82 Justice Powell apparently lobbied the other justices to grant certiorari "to reject the misappropriation theory once and for all." 83 But in a twist of history, Powell retired before Carpenter was argued. ${ }^{84}$ Consequently, the

75 Dirks, 463 U.S. at 666.

76137 S. Ct. 420, 427 (2016).

77 Chiarella v. United States, 445 U.S. 222, 235 (1980) (emphasis added).

78 Id. at 236.

79484 U.S. 19, 24 (1987).

80 Id. at 23 .

81 Id.

82 Id. at 24

83 Kurt A. Hohenstein, Fair to All People: The SEC and the Regulation of Insider Trading: Counterattack from the Supreme Court, SEC HisT. Soc'y, http://www.sechistorical.org/museum/galleries/it/counterAttack_d.php\#ftn43.

84 Id. 
Carpenter Court split four-to-four on the misappropriation theory's legality. 85

With the common law of insider trading in "limbo," the SEC sought help from Congress and proposed a statutory definition of insider trading. 86 Although Congress apparently stood ready to enact some version of the proposed statute, the SEC ultimately backed off, preferring, for enforcement, the common law's flexibility over statutory certainty. ${ }^{87}$ Congress did, however, respond to the SEC's calls for enhanced enforcement tools by passing the Insider Trading and Securities Fraud Enforcement Act of 1988 (ITSFEA). ${ }^{88}$ ITSFEA increased civil and criminal penalties generally, and extended the civil penalty of treble damages to "controlling persons" who "knew or recklessly disregarded the fact that [a] controlled person was likely to engage in [insider trading] and failed to take appropriate steps to prevent such" trading. 89 A principal purpose of this provision was to "increase the economic incentives" for corporations to "supervise vigorously their employees" through compliance programs and by other procedures. ${ }^{90}$

Despite questions concerning its legal validity, the SEC and prosecutors continued to bring misappropriation-theory cases for the next decade until the theory of liability finally received the Supreme Court's imprimatur in United States v. O'Hagan. ${ }^{91}$ James O'Hagan was a partner at a law firm representing Grand Metropolitan PLC in its tender offer for Pillsbury Company. ${ }^{92}$ Although O'Hagan did not work on the merger, he learned its details from others at the firm. ${ }^{93}$ He profited more than $\$ 4.3$ million by trading ahead of the merger. ${ }^{94}$ The classical theory

85 Carpenter, 484 U.S. at 24.

86 See generally Joseph Grundfest, Commissioner, SEC, Is the Sky Really Falling? The State of Insider Trading Law After the Winans Decision, Address at the Federal Bar Association (Jan. 26, 1988).

87 Id. at 2 (then-Commissioner Grundfest suggesting that it was best to put insider trading on the "legislative back burner" to allow the law "to evolve on a case-by-case basis in the courts"); see Jonathan R. MACEY, Insider TRAding: Economics, Politics, AND PoliCY 64 (1991) (quoting Congressman John Dingell as explaining that statutorily defining insider trading would "narrow [rather than enhance] the SEC's ability to bring enforcement actions").

88 ITSFEA, supra note 7.

89 Pub. L. No. 100-704, § 21A(b)(1)(A), 102 Stat. 4677; 15 U.S.C. § 78u-1(b)(1)(A). Issuers were previously subject only to normal damages for derivative liability for their employees' insider trading violations under the '34 Act's Section 20(a).

90 William K.S. WANG \& Marc I. Steinberg, Insider Trading 814-15 (3d ed. 2010) (quoting H.R. Rep. No. 100-910, at 17).

91521 U.S. 642 (1997).

92 Id. at 647.

93 Id.

94 Id. at 648. 
did not apply because he was neither an actual nor a constructive insider at Pillsbury. His trading, therefore, breached no fiduciary or similar duty of trust and confidence to his counterparties. Prosecutors charged him under the misappropriation theory and Rule 14e-3.95 O'Hagan embraced the misappropriation theory, whereby anyone (insider or outsider) incurs Section 10(b) insider trading liability if he or she misappropriates "confidential information for securities trading purposes, in breach of a duty owed to the source of the information."96

The Court reasoned that it would make little sense, under the classical theory, to hold an attorney liable for trading while representing a tender-offer target but fail to impose the same liability on an attorney who trades while representing the offeror. ${ }^{97}$ The Court explained that the two theories should be understood as "complementary":

The classical theory targets a corporate insider's breach of duty to shareholders with whom the insider transacts; the misappropriation theory outlaws trading on the basis of nonpublic information by a corporate "outsider" in breach of a duty owed not to a trading party, but to the source of the information. ${ }^{98}$

O'Hagan thus satisfied the "deceptive device or contrivance" requirement of Section 10(b) by "dup[ing]" his principals-his firm and its client-out of the exclusive use of their information by trading on it despite its confidentiality..$^{99}$

O'Hagan was also significant in that it offered the Court its first opportunity to address the question of whether the SEC had exceeded its legal authority in promulgating Rule 14e-3. The Eighth Circuit had held that Rule $14 \mathrm{e}-3$ was ultra vires to the extent that it imposed insider trading liability absent proof that the trading breached a duty of trust or confidence; in so holding, the court concluded that "fraud" must mean the same thing in the '34 Act's Section 14(e) as it means in Section 10(b). ${ }^{100}$ The Supreme Court held that it did not have to decide the question of whether the SEC had defined "fraud" inaccurately in Rule 14(e) because Congress intended 14(e) as a "prophylactic" against fraud in the tender-offers context. ${ }^{101}$ As such, "under § 14(e), the Commission may prohibit acts not themselves fraudulent under the common law or

95 Id. at 648-49.

96 Id. at 652 .

97 O'Hagan, 521 U.S. at 659.

98 Id. at 652-53.

99 Id. at 653-54.

100 Id. at 670-71.

101 Id. at 672-73. 
$\S 10(\mathrm{~b})$, if the prohibition is 'reasonably designed to prevent . . acts and practices [that] are fraudulent."'102 The Court did, however, limit its approval of the Rule 14e-3's application to the facts of $O^{\prime}$ Hagan and other cases "of this genre." 103 But it remains unclear how far the Court's approval of the SEC's exercise of its $\S 14(\mathrm{e})$ prophylactic power under Rule $14 \mathrm{e}-3$ would extend in cases where the trade did not breach a fiduciary or similar duty of trust and confidence. 104

\section{Twenty-First Century Developments and Unresolved Questions}

With O'Hagan, all the basic elements of insider trading liability enjoyed the Supreme Court's imprimatur: Section 10(b) insider trading liability (civil or criminal) arises where one looks to personally benefit from trading on, or tipping to another, material nonpublic information in breach of some fiduciary or similar duty of trust and confidence to the counterparty to the trade (classical theory) or the information's source (misappropriation theory). ${ }^{105}$ But certainty as to insider trading's basic elements has brought little clarity to the scope of the law's application.

Each element of Section 10(b) liability admits of substantial ambiguity and controversy that continues to bedevil market participants, the defense bar, and the government. ${ }^{106}$ For example, there exists significant disagreement over what constitutes a "personal benefit,"107 when trading is "on the basis of" information,108 when information is "material" 109 or "nonpublic," 110 what type of "fiduciary

102 Id. at 673.

103 O'Hagan, 521 U.S. at 672, 676.

104 ANDERSON, supra note 17, at 49 (noting that O'Hagan left open the possibility of reviewing, on different facts, the SEC's authority in promulgating Rule 14e-3).

105 See supra Section II.A.3.

106 See, e.g., ANDERSON, supra note 17, at 59-87.

107 E.g., BhARARA ET AL., supra note 6, at 8 ("Theories of insider trading have come and gone, and elements of the offense that once seemed well-settled (like the 'personal benefit' test) have at times been thrown into doubt by unexpected or unclear language in court decisions.").

108 E.g., John P. Anderson, Anticipating a Sea Change for Insider Trading Law: From Trading Plan Crisis to Rational Reform, 2015 UTAH L. Rev. 339, 347-50 (2015); Donald C. Langevoort, "Fine Distinctions" in the Contemporary Law of Insider Trading, 2013 Colum. Bus. L. REv. 429 (2013); Carol B. Swanson, Insider Trading Madness: Rule 10b5-1 and the Death of Scienter, 52 Univ. KAN. L. REv. 147 (2003).

109 E.g., Joan MacLeod Heminway, Just Do It! Specific Rulemaking on Materiality Guidance in Insider Trading, 72 LA. L. REv. 999 (2012); Joan MacLeod Heminway, Materiality Guidance in the Context of Insider Trading: A Call for Action, 52 AM. U. L. Rev. 1131 (2003).

110 E.g., Dirks v. SEC, 463 U.S. 646, 678 (1983) (Blackmun, J., dissenting) ("The [SEC] tells persons with inside information that they cannot trade on that information unless they disclose; it refuses, however, to tell them how to disclose."). The SEC has not since 
relation" triggers the duty to disclose, 111 and whether that relation must be one of "trust and confidence" (as articulated by Chiarella) ${ }^{112}$ or "trust or confidence" (as defined by SEC rule).113 The range of possible resolutions to these uncertainties has the potential to significantly expand or contract insider trading liability.

The SEC tends to interpret ambiguities in the law expansively so that the scope of liability will coextend with its original parity-ofinformation or equal-access vision, at least so far as courts will permit it.114 When the courts have pushed back against expansive theories of liability, the SEC resorted to rulemaking. 115 In 2000, for example, in response to judicial resistance to the SEC's position that "possession," rather than "use," in trading of material nonpublic information constituted trading "on the basis of" such information, the SEC promulgated Rule 10b5-1.116 Rule 10b5-1 defines trading "on the basis of" such information as simply trading while "aware" of such information."117 Similarly, in response to some courts' restrictive interpretation of when a fiduciary or similar duty of trust and confidence arises in the context of the misappropriation theory, as in the context of familial relationships, 118 the SEC adopted Rule 10b5-2 to provide explicitly for such a duty. ${ }^{119}$ Adopting these rules, however, did little to settle the legal controversy, which simply shifted to the question of whether the SEC had statutory authority to promulgate these rules. ${ }^{120}$

More recently, a dispute arose in the criminal context regarding the extent to which prosecutors can end-run around some of the harder-toprove elements of Section $10(\mathrm{~b})$ insider trading liability, like

issued a rule on what constitutes proper disclosure, or when information is "public," preferring a case-by-case approach. WANG \& STEINBERG, supra note 90, at 145.

111 E.g., ANDERSON, supra note 17, at 75-78.

112 See supra text accompanying note 53.

113 Langevoort, supra note 108, at 445.

114 See supra Section II.A.3.

115 See supra text accompanying notes 60-62.

116 See, e.g., BAINBRIDGE, supra note 18, at 71-74 (noting that the SEC adopted Rule 10b5-1 to resolve a split among circuits in the "use versus possession" debate).

11717 C.F.R. $\S 240.10 b 5-1$ (b).

118 See, e.g., United States v. Chestman, 947 F.2d 551, 568 (2d Cir. 1991), cert. denied, 503 U.S. 1004 (1992) (holding that a marriage relationship alone did not create a fiduciary or similar relation of trust and confidence for insider trading purposes).

11917 C.F.R. $\$ 240.10$ b5-2(3) (providing, inter alia, that there is a presumption of a relation of trust or confidence among spouses, parents, children, and siblings for purposes of insider trading liability).

120 See, e.g., Langevoort, supra note 108, at 445 (noting that some courts have questioned Rule 10b5-2's validity on the ground that trading does not constitute a breach of confidentiality and, further, a promise of confidentiality is not necessarily fiduciary). 
tipper/tippee liability's "personal benefit" test, by bringing the cases under other federal fraud statutes. The Securities and Commodities Fraud statute, 18 U.S.C. $\S 1348$, was adopted as part of the 2002 Sarbanes-Oxley Act. Congress presumably intended this statute to apply to accounting fraud. ${ }^{121}$ The Second Circuit nevertheless held in Blaszczak v. United States that Section 1348 applies to insider trading ${ }^{122}$ and that it effectively overrules Dirks in the criminal context by removing the personal-benefit element of tipper/tippee liability. ${ }^{123}$ Blaszczak so held despite Section 1348's tracking Section 10(b)'s language nearly verbatim. ${ }^{124}$ If Blaszczak is upheld, insider trading law will be burdened with still another controversy: proving criminal liability under Section 1348 will be easier than proving civil liability under Rule 10b-5.125

Lacking meaningful statutory side rails, the common law evolution of insider trading law has yielded an enforcement framework whose basic liability elements are problematically vague. Notwithstanding the Supreme Court's insistence on a fiduciary-fraud model, this vagueness has permitted the government to expand liability to the point of near-equivalence with the SEC's original vision of an equal-access or parity-of-information model. The result is a schizophrenic insider trading regime that the Supreme Court has shown little willingness to treat. 126

\section{B. Challenges and Controversies}

1. The Harmful Consequences of Ambiguity in the Law and Call for Reform

The tension in insider trading law imposes on the investing public some of the harms that the securities laws were implemented to prevent. Its vagueness has resulted in significant uncertainty for traders, issuers, and the broader market. As Jackson and Bharara put it,

121 See, e.g., Brief of Amici Curiae Law Professors in Support of Defendant-Appellants' Petition for Rehearing and for Rehearing En Banc at 4-7, United States v. Olan, $2020 \mathrm{WL}$ 1040819 (2020).

122 United States v. Blaszczak, 947 F.3d 19, 36-37 (2d Cir. 2019).

123 See Andrew N. Vollmer, The Second Circuit's Blaszczak Decision: Dirks Besieged (Jan. 11, 2020), https://ssrn.com/abstract=3516082.

124 See Karen E. Woody, The New Insider Trading, 52 ArIZ. ST. L.J. 594, 616 (2020).

125 Id. at 600, 615 (noting that the SEC cannot bring actions under Section 1348 because it lacks criminal-enforcement power).

126 See, e.g., ANDERSON, supra note 17, at 80 (noting with respect to Salman, the Court's first insider trading case in nearly 20 years, which did little more than reaffirm Dirks, that many "were surprised that the Court had waited so long to say so little"). 
the area's "legal haziness ... leaves both investors and defendants unclear about what sorts of information-sharing or other activities by investors would be considered insider trading, and what are the acceptable forms of data-gathering and research that are part of any healthy, functioning financial marketplace."127 Such uncertainty, combined with the threat of what some have termed "draconian" sanctions, places market efficiency at risk and raises significant due process concerns. ${ }^{128}$

The lack of clarity may, for example, force fund managers to refrain from making trades that will benefit their investors simply because the law gives them no clear guidance (even with the assistance of counsel) on whether the trade is perfectly legal or will land them in prison.129 Similarly, this lack of clarity leaves compliance departments at issuers and financial institutions helpless in drafting clear insider trading compliance programs. ${ }^{130}$

Issuers and financial institutions thus find themselves in difficult situations. ${ }^{131}$ For, given that corporations can be held derivatively liable for their employees' insider trading, ${ }^{132}$ and that prosecutors have signaled that they will look to compliance programs to determine whether to prosecute corporations (and the Federal Sentencing Guidelines look to compliance in determining their "culpability score"),133 issuers are compelled to institute overbroad "play-it-safe," compliance programs that end up precluding good-faith, efficient trades. ${ }^{134}$ Paradoxically, insider trading law's ambiguities may inhibit, rather than promote, proper market functioning. 135

Moreover, in Kolender v. Lawson, the Supreme Court held that, to satisfy the demands of due process, "a penal statute [must] define the criminal offense with sufficient definiteness that ordinary people can understand what conduct is prohibited and in a manner that does not

127 Bharara \& Jackson, supra note 1.

128 Stephen M. Bainbridge, Incorporating State Law Fiduciary Duties into the Federal Insider Trading Prohibition, 52 WASH. \& LEE L. REV. 1189, 1191 (1995).

129 See, e.g., BHARARA ET AL., supra note 6, at 1 (noting that the law's vagueness has "left market participants without sufficient guidance on how to comport themselves").

130 See, e.g., John P. Anderson, Solving the Paradox of Insider Trading Compliance, 88 TEMP. L. REv. 273, 287-95 (2016).

131 Id. at 295-96.

13215 U.S.C. $\S 78 \mathrm{t}(\mathrm{a})$.

133 See, e.g., Justice Manual Section 9-28.300, available at https://www.justice.gov/ jm/jm-9-28000-principles-federal-prosecution-business-organizations\#9-28.300; see also U.S. SENT'G COMm'N, U.S. SENT'G GUIDELINES MANUAL § 8C2.5(f) (2014).

134 See Anderson, supra note 130, at 295.

135 Id. at 296. 
encourage arbitrary and discriminatory enforcement."136 With SEC commissioners, prosecutors, and sophisticated market professionals confounded, insider trading law's due process tension is palpable,137 even if the courts have never held it to be unconstitutional.

The historic justification for vagueness in the law of insider trading has been that it aids enforcement by granting maximum flexibility to the SEC and federal prosecutors in bringing their cases. ${ }^{138}$ Although such justifications should be regarded with a dubious eye in liberal democracies, they may have some merit in limited circumstances where the risks to the public are particularly great and the criminal penalties are moderate. ${ }^{139}$ Whether insider trading over anonymous exchanges is economically harmful or unethical has been hotly contested since Chairman Cary introduced the crime in the early 1960s, ${ }^{140}$ and the criminal penalties for insider trading are severe (up to twenty years under Section $10(\mathrm{~b}),{ }^{141}$ and up to twenty-five years under Section 1348). ${ }^{142}$

For these and other reasons, scholars and jurists alike have reached near unanimity in their call for reform, ${ }^{143}$ and Congress is poised to act.144 It would, however, be unwise to respond to sixty years of controversy over the appropriate scope of insider trading liability (with some arguing that the practice should be legal) by adopting a hastily drafted statutory definition. Any new statute should be informed by a clear understanding of the economic harms and moral wrongs that the law will target. As the following two subsections explain, the availability of up-to-date empirical evidence will be crucial to achieving informed insider trading reform.

\footnotetext{
136 Kolender v. Lawson, 461 U.S. 352, 357 (1983).

137 See Homer Kripke, Manne's Insider Trading Thesis and Other Failures of Conservative Economics, 4 CAто J. 945, 949 (1985) (arguing that Rule 10b-5 should be declared "unconstitutionally vague").

138 BAINBRIDGE, supra note 18, at 143 n.30.

139 For example, the law sometimes imposes strict liability for "public welfare offenses" where the risks to the public concerning particularly dangerous conduct are great. See, e.g., Morissette v. United States, 342 U.S. 246, 252-56 (1952). Such crimes, however, are usually accompanied by minimal penalties. Id. at 256.

140 See infra Section II.B.2.

14115 U.S.C. $\S 78 f f(a)$.

14218 U.S.C. $§ 1348$.

143 See, e.g., BHARARA ET AL, supra note 6, at 1; Henning supra note 2, at 751.

144 See supra notes 8-9 and accompanying text.
} 
2. Ongoing Debate over the Economics and Ethics of Insider Trading

Since Professor Henry Manne's germinal 1966 book, Insider Trading and the Stock Market, scholars have debated the economic impacts of insider trading. ${ }^{145}$ Manne and others have argued that it can generate net benefits to securities markets. For example, insiders are ideally situated to assess the true value of their own companies in real time. To the extent that their trading affects stock prices, it pushes them toward greater accuracy more efficiently, with lower litigation risk than formal disclosure.146 Professor Jonathan Macey argues that the price accuracy offered by insider trading is crucial to healthy markets because it fosters efficient capital allocation. ${ }^{147}$

Insider trading may also provide a useful "market-smoothing" function. ${ }^{148}$ If insiders trade leading up to disclosure, price moves gradually rather than suddenly as happens when markets must digest information quickly. This "dampening of price fluctuations decreases the likelihood of windfall gains and increases the attractiveness of investing in securities for risk-averse investors." ${ }^{149}$ Insider trading may thus make markets more attractive for many investors.

Economists have also identified insider trading's benefits for issuers. Price movements from insider trading can serve as "red flags" to management of a fraud or some other issue, allowing management to isolate and address the problem in real time without having to wait "for the bureaucratic pipeline to deliver a memorandum." 150 Insider trading can also serve as an efficient means of executive compensation, offering savings to shareholders in terms of reduced executive salaries, while incentivizing and rewarding in-firm entrepreneurship. ${ }^{151}$

145 MANNE, supra note 41.

146 See, e.g., Stephen Bainbridge, Insider Trading, Encyc. OF L. \& Econ. § 5650 (1999); Dennis W. Carlton \& Daniel R. Fischel, The Regulation of Insider Trading, 35 STAN. L. REV. 857, 868 (1983); Henry G. Manne, Insider Trading and the Law Professors, 23 VAND. L. REV. 547, 548 (1970).

147 MACEY, supra note 87, at 10 (adding that "misallocation of society's resources will lead to unemployment, low productivity, and higher interest rates").

148 Manne, supra note 146, at 574.

149 Bainbridge, supra note 146.

150 MACEY, supra note 87, at 37; Henry G. Manne, Insider Trading: Hayek, Virtual Markets, and the Dog that Did Not Bark, 31 J. CoRP. L. 167, 176, 181 (2005) (also noting that some firms set up internal virtual-trading markets to inform their decision-making).

151 Ian Ayers \& Steven Choi, Internalizing Outsider Trading, 101 Mich. L. REV. 313, 338 (2002); Manne, supra note 146, at 579. There is some empirical evidence that issuers do adjust salary based on the stringency of the firms' insider trading policies. E.g., M. Todd Henderson, Insider Trading and CEO Pay, 64 VAND. L. REV. 505, 509-10 (2011). 
Economists have also identified potential harmful effects of insider trading. The adverse-selection model holds that if insider trading is prevalent, "because of order imbalances and the difficulty of sustaining a liquid market only with matching [orders], a liquidity provider has to transact with his own inventory and thus bears the risk of consistently buying 'high' from and selling 'low' to insiders." 152 Market makers will respond by increasing their bid-ask spreads to compensate for consistently losing trades against insiders. This effective tax on all market participants may lead to reduced liquidity, and therefore an increase in the issuer's cost of capital. The higher a firm's cost of capital, the less flexibility it will have to grow. ${ }^{153}$

Insider trading also has the potential to create moral hazard. "[I]nsider trading might simply be an inefficient private benefit of control that accrues to managers and other insiders." ${ }^{154}$ Managers might delay disclosures to provide time to free up capital for their trades or to allow time for their tippees to trade. 155 And because insiders can profit from any stock-price movement, they may have the perverse incentive to generate bad news in order to profit from short positions in their own company's shares. 156

Insiders may deprive the owner of material nonpublic information - the issuer or insider's employer - of its "right of exclusive use."157 Where insider trading violates the issuer's instructions or is misappropriated, it is hard to dispute that some harm results. ${ }^{158}$

The question of insider trading's net economic impact is far from resolved. As one commentator put it, the empirical evidence supporting the theoretical economic arguments for and against insider trading is "so limited and weak that any conclusions . . . should be regarded with

152 Stanislov Dolgopolov, Insider Trading and the Bid-Ask Spread: A Critical Evaluation of Adverse Selection in Market Making, 33 CAP. U. L. REv. 83, 98 (2004).

153 Laura Nyantung Beny, Insider Trading Laws and Stock Markets Around the World: An Empirical Contribution to the Theoretical Law and Economics Argument, 32 J. CoRP. L. 237, 249 (2007); Dolgopolov, supra note 152, at 100-01; see supra note 147 and accompanying text.

154 Beny, supra note 153 , at 243.

155 See Roy A. Schotland, Unsafe at Any Price: A Reply to Manne, Insider Trading and the Stock Market, 53 VA. L. REv. 1425, 1448-49 (1967); Morris Mendelson, The Economics of Insider Trading Reconsidered, 117 U. PA. L. REv. 470, 476-77 (1969).

156 See, e.g., Saul Levmore, Securities and Secrets: Insider Trading and the Law of Contracts, 68 VA. L. REv. 117, 149 (1982).

157 United States v. O'Hagan, 521 U.S. 642, 654 (1997).

158 If such trading did not impose some cost on the information's source, there would be no reason for the owner of the information to have denied the right to trade on it in the first place. See, e.g., Ayers \& Choi, supra note 151, at 354-55 (noting that "the traded firm itself ... is much better situated to decide whether particular classes of informed trading are socially beneficial"). 
restraint."159 Yet the area's key players appear unfazed by this impasse, likely because many proponents of insider trading regulation justify it in attitudinal terms. They typically justify harsh penalties for insider trading as necessary to protect "investor confidence" by ensuring that markets are perceived as "fair."

3. Market Confidence, Fairness, and the Importance of Empirical Evidence of Public Attitudes to Reform Efforts

Protecting the perceived confidence in the "fairness" and "integrity of our securities markets" is perhaps the most frequently-cited justification offered in defense of insider trading laws. ${ }^{160}$ Three basic premises appear to be implicit in the market-confidence theory: (1) a large portion of the general public believes that insider trading is unfair and pervasive; (2) this widespread perception leads those who share it to reduce or end their market participation; and (3) rigorous enforcement of insider trading is, therefore, necessary to prevent the harsh consequences to markets (e.g., reduced market liquidity and increased issuer cost of capital) that would result from (2). ${ }^{161}$

But, as premises (1) and (2) above reflect, the market-confidence theory turns on empirical claims concerning public attitudes. It would be imprudent to push forward with new legislation statutorily criminalizing insider trading based on the market-confidence concern without validating these claims. ${ }^{162}$

159 Laura E. Hughes, The Impact of Insider Trading on Stock Market Efficiency: A Critique of the Law and Economics Debate and a Cross-Country Comparison, 25 TEMP. InT'L \& Comp. L.J. 479, 505 (2009); accord Charles C. Cox \& Kevin S. Fogarty, Bases of Insider Trading Law, 49 Онго Sт. L.J. 353, 357 (1988) ("it cannot conclusively be said that the economic benefits outweigh the costs of prohibiting insider trading" because "[ $t$ ]he comparative costs and benefits have not been quantified")

160 BhARARA ET AL., supra note 6, at 1; Selective Disclosure and Insider Trading: Final Rule, 65 Fed. Reg. 51,715 (Aug. 24, 2000); accord Bainbridge, supra note 128, at 1234 (ranking "maintaining public confidence in the securities market" as one of the principal rationales for regulating insider trading); H.R. Rep. No. 100-910, at 7-8 (1988) (expressing concern that investors will not participate in markets perceived to be "rigged" by insider trading); Steve Schaefer, Wall Street Sheriff Preet Bharara Talks Insider Trading, FoRBEs (Jul. 18, 2012, 3:58 PM), https://www.forbes.com/sites/steve schaefer/2012/07/18/wall-street-sheriff-preet-bharara-talks-insider-trading/\#727e0 a2b6690; see supra notes 15-16 and accompanying text (Bharara asserting that aggressive prosecution of insider trading is important to enliven "confidence in the market").

161 See, e.g., John P. Anderson, Insider Trading and the Myth of Market Confidence, 56 WASH. U. J.L. \& POL'Y 1, 1-2 (2018).

162 See Committee on Federal Regulation of Securities, Report of the Task Force on Regulation of Insider Trading, 41 Bus. L. 223, 227-28 (1985) ("Although the task force knows of no empirical research that directly demonstrates that concerns about integrity 
Similarly, appeals to fundamental "fairness" as a justification for the regulation of insider trading are rarely accompanied by rigorous philosophical demonstration.163 Instead, arguments concerning the fairness of insider trading typically assume that "most agree," or appeal to "common sense."164 Such appeals demand empirical support-particularly in the context of insider trading where, as noted above, the law has permitted parties to profit from trading based on "unerodable" information asymmetries for centuries without regarding it as unfair. 165 Consequently, it seems wise to empirically determine whether the public actually thinks it is fundamentally unfair, and under what circumstances.

Finally, one risk in basing legislative codification, particularly in the criminal law, on current public attitudes is that, even if empirical evidence supports the claim that these attitudes are shared, the public may be misguided or wrongheaded in holding these views. Such false consciousness may result from cultural bias, media spin, incomplete information, and the like. It is therefore important that lawmakers be apprised of any empirical evidence suggesting public attitudes are adulterated by such factors.

Although there have been efforts to sound public attitudes concerning insider trading in the past, 166 this Article's goal is to inform reform efforts by providing the first large-scale, census-representative national survey on the topic since 1986. In what follows, Part III describes the survey instrument and Part IV presents the results.

\section{THE SURVEY INSTRUMENT}

The survey's primary goal was to update and broaden the state of knowledge of national views on insider trading. First, it aimed to advance the state of the art of insider trading knowledge by creating a more nuanced and comprehensive catalog of societal perceptions about the field. The hope is that, combined with future work, ${ }^{167}$ it will provide

affect market activity, both authoritative commentators and common sense tell us that if investors do not anticipate fair treatment, they will avoid investing in securities.").

163 See, e.g., BAINBRIDGE, supra note 18, at 192 (noting that the usual "vague and poorly articulated notions of fairness surely provide an insufficient justification for [insider trading] prohibition").

164 BhARARA ET AL., supra note 6, at 3; Committee on Federal Regulation of Securities, supra note 162, at 227.

165 See Selective Disclosure and Insider Trading: Final Rule, supra note 160; supra Sections II.A.1-2.

166 See supra note 14.

167 See infra Part V. 
a robust knowledge base on which policymakers, courts, scholars, and others can rely.

The study's second aim was to compare general public impressions about, and attitudes toward, insider trading in 2019 with those expressed in the famous pair of 1986 Business Week surveys. ${ }^{168}$ Much has changed over the last several decades, including vast technological improvements, shifts in political views and demographics, and fluctuations in general understanding of and participation in equities markets. ${ }^{169}$ Although valuable, the Business Week surveys were short and relatively simple. ${ }^{170}$

This Part first discusses the study's strategy for optimizing, within its constraints, the survey's effectiveness in gathering the relevant data. It then describes the methodology used to collect that information. It concludes by noting the survey's limitations.

\section{A. Survey Strategy}

The survey rested on two building blocks. The first was a set of topics related to insider trading that would benefit from being informed by public opinion. The second comprised insights gained from conversations with empiricists, surveying scholarship, and legal literature presenting the results of public surveys. ${ }^{171}$ These informed the task at hand and the development of baseline practices. A professional polling firm then administered the survey to a

168 Business Week 12/86, supra note 14; Business Week 8/86, supra note 14.

169 See Katie Kolchin, A Chart BooK on Stock Ownership (2019); B. Ravikumar, How Has Stock Ownership Trended in the Past Few Decades?, Fed. Res. BAnK OF ST. LouIs (Apr. 9, 2018), https://www.stlouisfed.org/on-the-economy/2018/april/stock-ownershiptrended-past-few-decades.

170 The August and December surveys contained nine and eight questions. See Business Week 12/86, supra note 14; Business Week 8/86, supra note 14.

171 E.g., Stephen B. Hulley et Al., Designing Clinical Research (4th ed. 2013); Courtney Megan Cahill \& Geoffrey Christopher Rapp, Does the Public Care How the Supreme Court Reasons? Empirical Evidence from a National Experiment and Normative Concerns in the Case of Same-Sex Marriage, 93 N.C. L. REv. 303 (2015); Matthew B. Kugler \& Lior Jacob Strahilevitz, Assessing the Empirical Upside of Personalized Criminal Procedure, 86 U. CHI. L. REv. 489 (2019); Matthew B. Kugler \& Lior Jacob Strahilevitz, The Myth of Fourth Amendment Scrutiny, 84 U. CHI. L. REv. 1747 (2017); Matthew B. Kugler \& Lior Jacob Strahilevitz, Actual Expectations of Privacy, Fourth Amendment Doctrine, and the Mosaic Theory, 2015 SuP. CT. REv. 205; Lior Strahilevitz \& Omri Ben-Shahar, Interpreting Contracts via Surveys and Experiments, 92 N.Y.U. L. REv. 1753 (2017). 
census-representative group of 1,313 respondents in April 2019.172 With this sample size, the survey-level margin of error is \pm 3 percent. ${ }^{173}$

Census representativeness-across age, gender, race, and other categories-was important because insider trading law and policy is set almost entirely at the national level. ${ }^{174}$ More than half of the nation's population ${ }^{175}$ invests in equities, directly or indirectly. ${ }^{176}$ Ownership spans all income groups. ${ }^{177}$ And in today's enforcement climate, it is relatively easy for the unknowing-professionals and investing individuals alike-to be caught up in an insider trading investigation. ${ }^{178}$

The survey, in other words, had to be temporally and historically relevant. Practical considerations, however, limited what could be accomplished in one instrument. If the survey was too long or too involved, respondents might abandon or be overwhelmed by it; therefore, content had to be limited. It was important to obtain updated figures on the key questions from the 1986 Business Week surveys about the pervasiveness of insider trading, whether the practice should be illegal, and whether respondents would trade on a tip. ${ }^{179}$

172 These 1,313 respondents passed screening criteria to ensure that they were taking the study seriously. See infra note 198. The actual number of respondents was higher.

173 See infra note 209 and accompanying text; text accompanying notes 207-08.

174 States also have IT laws. E.g., Cal. Corp. Code $§ 25402$ (Deering 2020); N.Y. Gen. Bus. Law § 352-c (Consol. 2020); Vt. Stat. Ann. 9, § 4301 et seq. (2020); see also People v. Napolitano, 282 A.D.2d 49 (N.Y. App. Div. 2001) (affirming an insider trading conviction based on N.Y. Gen. Bus. Law $\S 352-c)$. Nevertheless, the Securities Exchange Commission and Department of Justice are the usual plaintiffs in insider trading actions.

175 The survey included both citizens and noncitizens.

176 Gary MotTola, InSights: FinANCIAL CAPABILITY: A SNAPSHOT OF INVESTOR HouSEHOLDS IN AMERICA 1 (2015) ("Approximately 6 in 10 households"); Board of Governors of the Federal Reserve System, Changes in U.S. Family Finances from 2013 to 2016: Evidence from the Survey of Consumer Finances 103 FED. RES. BuLL. 20-21 (Sept. 2019) ("51.9 percent of families"); Jeffrey M. Jones, U.S. Stock Ownership Down Among All but Older, Higher-Income, GALLUP (May 24, 2017), https://news.gallup.com/poll/211052/stockownership-down-among-older-higher-income.aspx.

177 Board of Governors of the Federal Reserve System, supra note 176, at 20.

178 See, e.g., Thomas A. Firey, Why Is Insider Trading Illegal?, CATo InST. (May 15, 2017, 11:28 AM), https://www.cato.org/blog/why-insider-trading-illegal (former baseball player). Joe Gyan Jr., Ruston Dentist Acquitted of Insider Trading Related to Sale of Shaw Group in Baton Rouge, Advocate (Aug. 10, 2017, 4:15 PM), https://www.the advocate.com/baton_rouge/news/business/article_823c64dc-7c8b-11e7-a307-

73dcfa0f6461.html (dentist). Even an acquittal is devastating. William Alden, F.B.I. Raid Was Blamed for the Demise of Two Hedge Funds, N.Y. TIMEs, Dec. 11, 2014, at B2; William D. Cohan, Overturned, ForTunE, Sept. 1, 2016, at 90.

179 See Business Week 12/86, supra note 14 at 34; Business Week 8/86, supra note 14 at 74 . 
The survey had to cover the basic propositions and theories set out by various players in the insider trading debate, like the fiduciary-dutybased theories and approaches applied in controlling case law, justifications for the competing parity-of-information and equal-access models, the market-confidence theory, questions of morality, questions of criminality, and other controversies discussed in Part II. Both absolute and relative measures-like whether one of the basic theories of insider trading liability (classical or misappropriation) was regarded as more just, or whether respondents fair-punishment views changed when considering them in the abstract versus applied to themselves-were important.

The resulting data had to be "deep as well as broad" 180 so that it would provide an objective basis for characterizing public opinion across many dimensions. It was important to know, for example, whether the public believed that insider trading, in the abstract, was immoral and, separately, should be illegal.181 To robustly test various theories, it was equally important to learn morality and legality views about insider trading in its various forms and under various circumstances.

There was further benefit to approaching the individual points of inquiry from multiple angles. Multiple questions, and juxtapositions of questions, tested the examined propositions. Testing individual theories and propositions this way provided internal cross-checks and allowed for more conclusions to be drawn with increased confidence.

This style of questioning yielded insight into how well-formed and strongly held public opinions were on these subjects. Juxtaposing answers to each of two questions about the morality and legality of insider trading, for example, revealed information that illumined how strongly individuals held the beliefs that they expressed directly in answer to each of the questions. ${ }^{182}$ Comparing respondents' answers about general punishment for insider trading versus what it should be for themselves if they were caught could yield insight on how

180 Eric Ruben \& Joseph Blocher, From Theory to Doctrine: An Empirical Analysis of the Right to Keep and Bear Arms After Heller, 67 DuKE L.J. 1433, 1433 (2018).

181 There is an ongoing debate, engaged in most famously by H.L.A. Hart and Patrick Devlin, about whether all that is immoral should be criminally punished. Compare H.L.A. HART, LAW LIBERTY AND MORALITY (1963) (arguing that morals should not be enforced via legal sanction), with PATrick Devlin, The Enforcement of Morals (1959) (arguing the opposite); see Peter Cane, Taking Law Seriously: Starting Points for the Hart/Devlin Debate, 10 J. Eтнісs 21 (2006) (describing the Hart-Devlin debate); supra text accompanying note 59 ("not every instance of financial unfairness constitutes fraudulent activity under $\S 10(\mathrm{~b}) "$ ).

182 See infra Section IV.D.2. 
well-considered respondents' initial punishment views were. ${ }^{183}$ Similarly, having respondents face related follow-up questions after having been exposed to various policy arguments (for, neutral, and against)—unceremoniously dubbed "propaganda" herein-regarding insider trading could reveal the extent to which opinions are subject to outside influences. ${ }^{184}$

Although public opinion should not be the sole factor informing reform efforts, it should be a substantial part of that inquiry, particularly in the insider trading context. ${ }^{185}$ As Professors Green and Kugler point out, a disjunction between social views about a behavior's propriety and the criminal law's treatment of it causes the law to seem unfair, and ultimately lose credibility and effectiveness. ${ }^{186}$ Similarly, because law tends to shape and inform social norms, ${ }^{187}$ punishing too broadly also threatens the regime's legitimacy. 188 Indeed, if one believes that fairness is simply a function of social views, one might say that a law is unfair if it is misaligned with public attitudes. ${ }^{189}$ This effect "increases substantially" "when it is not intuitive that certain criminalized conduct is wrong." 190

Professor John F. Stinneford shows that the common law is thought to reflect longstanding propositions enjoying universal acceptance, and thus reason, while externally imposed sovereign commands were suspect. ${ }^{191}$ The common law is also widely, albeit not universally, believed to produce more efficient-including more predictableresults. ${ }^{192}$ The longstanding disjunction between the common law of,

183 See infra Section IV.D.3.

184 See infra Section IV.E.

185 See supra Section II.B.3; $c f .6$ McCarthy on Trademarks AND Unfair Competition $\S 32: 195$ (5th ed. 2020) (noting, in the trademark context, that "[w]hile the courts are careful in writing opinions not to place all their evidentiary eggs in the survey basket, starting in last two decades of the 20th Century, an increasing number of judicial opinions expressly rely upon survey evidence to substantiate the decision")

186 Green \& Kugler, supra note 14, at 450-51 (citing sources).

187 See RichARD McAdAMS, The EXPRESSIVE POWER OF LAW (2015).

188 See Green \& Kugler, supra note 14, at 451.

189 Cf. U.S. Const. amend. VIII; John F. Stinneford; The Original Meaning of "Cruel", 105 GEO. L.J. 441, 470 (2017) (noting that the Eighth Amendment intended to bar punishments misaligned with "universal, longstanding custom").

190 Green \& Kugler, supra note 14, at 451.

191 John F. Stinneford, The Original Meaning of "Unusual": The Eighth Amendment as a Bar to Cruel Innovation, 102 Nw. U. L. REv. 1739, 1772-87 (2008). "Reason," here, refers to an amalgamation of concepts like common sense and natural law. Id. at 1772, 1772 n.193, 1773, 1773 n.202, 1773 n.203. They can be summarized as "universal, abstract principles of justice." Id. at 1774.

192 See Richard A. Posner, Economic Analysis of LAW 249, 251 (7th ed. 2007); Frank B. Cross, Identifying the Virtues of the Common Law, 15 Sup. CT. ECoN. REv. 21, 21-22 (2007) 
and regulatory behavior toward, insider trading was, therefore, worthy of examination. ${ }^{193}$

This Article's goals are primarily descriptive. It offers some analysis, but only to enhance the study's descriptive strength. Although it is tempting to draw why conclusions at this stage, that would be premature because this survey illuminates the topics about which detailed why questions should be asked.194

\section{B. Survey Design and Administration}

The survey was administered online using written instructions. ${ }^{195}$ Online administration allowed for a substantially larger sample size given a fixed budget, enhancing precision. 196 Written surveys are typically more uniform and efficient, and "written information is more likely to be retained by research subjects."197

The survey was divided into three stages. Stage 1 elicited opinions about insider trading directly. Stage 2 asked participants to imagine themselves in the roles of individuals who had the opportunity to trade on material nonpublic information in various situations. Some respondents were asked whether trading in those roles would be ethical. Others were asked whether they would, in fact, trade if they found themselves in the described situations. The survey included two

(citing sources); id. at 24-41 (discussing theories for the common law's alleged superiority over legislative and administrative lawmaking); Paul H. Rubin, Why Is the Common Law Efficient?, 6 J. LEGAL STUD. 51 (1977); Jeffery Evans Stake, Evolution of Rules in a Common Law System: Differential Litigation of the Fee Tail and Other Perpetuities, 32 FLA. ST. U. L. REV. 401, 401-02 (2005) (citing a comprehensive array of sources and noting that in the common law "there is a feedback loop, a mechanism that returns the output of a system back to the system's input, that provides courts with opportunities to overturn inefficient common law ... rules"); id. at 404-10 (describing common law mechanisms and processes that favor efficient results). Professor Cross empirically compares the common and civil law, finding that the former is superior in some areas, like predictability, but finding no difference in others. See Cross, supra, at 46-57.

193 See supra text accompanying note 126.

194 This is planned for upcoming work. See infra Section V.

195 The survey script, available in full in Appendix A, available at http://dx.doi.org/ $10.15786 / 20.500 .11919 / 7122$, was crafted into an online survey using Qualtrics. Respondent selection was designed to achieve a census-representative sample by Dynata, a reputable provider of first-party survey and research data. See Our Company, DYNATA, https://www.dynata.com/company/ (last visited Jan. 2, 2021); About Dynata, DYNATA, https://www.dynata.com/company/about-us/ (last visited Jan. 2, 2021).

196 See supra notes 172-73 and accompanying text.

197 Kugler \& Strahilevitz, supra note 171, at 497-98 (citing a study of Miranda warnings); see HULLEY ET AL., supra note 171, at 232; see also DIANE L. SCHALLERT ET AL., ANALYSES OF DifFERENCES BETWEEN WRITTEN AND ORAL LANGUAGE 6 (University of Illinois at Urbana-Champaign, Technical Report No. 29, Apr. 1977) ("Readers can sample the text in the most efficient way for their purposes, while listeners must follow the material as the speaker presents it...."). 
screening questions asking respondents to enter specified text; answers of respondents who did not enter the specified text were excluded from the data set.198 Answering any given question was optional. Stage 3 asked for demographic information.

Stages 1 and 2 are detailed in the next two subsections. Section II.C discusses the survey's key limitations. Part IV presents and discusses the survey's findings.

\section{Stage 1: Direct Assessment of Insider Trading Views}

Stage 1 asked participants a basic set of direct questions about their general attitudes about insider trading. Most of these questions were objective, presenting respondents with two to four answer choices. Participants were asked eight to ten objective questions, with two of the questions asked, or not, depending on respondents' answers to previous questions. ${ }^{199}$ Answers to these questions did not have to be coded; they were used as-is.

198 Appendix A, at 3, 6, available at http://dx.doi.org/10.15786/20.500.11919/7122. The two screening questions were included (1) between Stages 1 and 2, and (2) before the propaganda section in Stage 2, to determine whether respondents were reading questions and answering them to the best of their abilities, or merely selecting random answers to get to the end of the survey. Because survey respondents were compensated, this additional step was added to minimize the number of respondents who would click through the questions quickly simply to receive payment. See infra Section IV.E.2.

199 The survey is available in full in Appendix A, available at http://dx.doi.org/10.157 86/20.500.11919/7122. The objective questions are paraphrased here:

Q1 How common is insider trading?

Q2 Do you personally invest in stocks?

Q3 What might keep you from investing?

Q3.a Would insider trading in a stock you like make

you more, less, or equally likely to buy it?

Q4 Would insider trading in the market prevent you from investing in it?

Q5 Would you trade on inside information?

Q6 Is insider trading morally wrong?

Q7 Should insider trading be illegal?

Q7.a How should inside traders be punished?

Q7.b How should you be punished for inside trading?

Questions 1, 2, 3, 3.a, 4, 5, 6, and 7 were objective and posed to all participants. Questions 7.a and 7.b were objective and posed to only those participants who answered Question 7 in the affirmative. 
Respondents were also asked one or two of four possible open-ended questions, and the total again depended on the answers to previous questions. ${ }^{200}$ Answers to these questions were coded by a law student research assistant whom one of the Authors trained. The coding was straightforward enough that a student could be trusted with it. A spot-check revealed that the work was accurate. Student coding also minimized the likelihood that subconscious author bias would impact the results. ${ }^{201}$ In any event, the survey's results are less prone to subjective biases because only a small proportion of its responses required coding.

Stage 1 was followed by a screening question, ${ }^{202}$ and then Stage 2, discussed below.

\section{Stage 2: Scenario-Based Assessment of Insider Trading Views}

Stage 2 employed scenario-based, role-playing questions to indirectly elicit participants' attitudes toward insider trading in various situations. The objective scenarios were coupled with short propaganda narratives about alleged benefits or harms of insider trading. The Stage's goals were twofold. First, it aimed to determine public instincts about insider trading in situations implying fiduciary or other relational duties. Second, it sought to ascertain the malleability of respondents' sentiments about insider trading.

Upon entering Stage 2, participants were channeled into one of two tracks: ethical or pragmatic. Respondents were then presented with a series of five scenarios related to the purchase of a small corporation by

200 The open-ended questions are paraphrased here:

Q3.b One of Q3.b.1-3 based on answer to Q3.a

Q3.b.1 [more likely] Why?

Q3.b.2 [less likely] What about insider trading would make you less likely?

Q3.b.3 [equally likely] Would any amount of insider trading change your mind?

Q5.a [if Q5 answered No] What factors would stop you?

Question 5.a was asked only to participants who answered Question 7 in the negative. The actual answers to the open-ended questions are available in Appendix B.

201 Mark A. Hall \& Ronald F. Wright, Systematic Content Analysis of Judicial Opinions, 96 CALIF. L. REv. 63, 111 (2008) (stating, in the context of coding judicial opinions, that "[f]rom a social science perspective, [scholar, as opposed to student, coding] is the height of unmitigated subjectivism-the opposite of good scholarship"). Much of Hall \& Wright's article, especially Part IV, is a catalog of best practices for performing case coding. Many of its recommendations apply to a broad range of empirical studies.

202 See supra note 198 and accompanying text. 
a larger one. The survey asked participants to imagine themselves in five roles connected to the small firm in which they were exposed to profitable material nonpublic information. In the ethical cohort, for each role, participants were asked whether it would be ethical to buy, first, the small target firm's stock and, second, the large acquiring firm's stock. Participants in the pragmatic track were asked whether they actually would buy in the given situation.

In the first scenario, participants were asked to imagine themselves as the CEO - the archetypical insider-of the small firm. From there, they were asked to step into the shoes of, in turn, a janitorial employee of the firm, an outside accountant hired to audit the firm, the friend of a middle manager of the firm at a holiday party, and a quasi-stranger who encountered a brokerage-firm-employee neighbor in an elevator. Half of each track was presented with the scenarios in reverse order to reveal whether question order influenced responses.

Each track was further divided into two groups. Half of the ethical track was told, in conjunction with assuming the role of CEO of the small firm, that the firm had expressly granted permission to insiders in their positions to trade on firm information. Half of the pragmatic track was asked whether they would trade on the information presented to them in each scenario knowing that they could do so "without getting caught."

After respondents passed through all five scenarios, they were randomly selected to hear and read $^{203}$ a piece of text expounding one of three propaganda statements regarding insider trading. One exposition presented the traditional fairness view of insider trading, explaining how it is unfair and detrimental to markets. Another was neutral, asserting that insider trading likely had no meaningful impact. A third presented a positive view of insider trading, explaining how it could benefit individual investors and markets. Equal proportions of participants were presented with each exposition.

After listening to and reading the text, respondents were again asked to imagine themselves in situations that were designed to be substantively analogous to the original own-company scenarios that

203 Although written questionnaires tend to be superior to interviews, see supra note 197 and accompanying text, "[c]ognitive research has established the fact that humans process information by means of two distinct channels-one for visuospatial information and one for auditory-verbal information. A given piece of information can be organized and 'stored' in memory in either or both of these representational systems. According to dual-coding theory, information that is represented in both formats is more likely to be recalled than information that is stored in either format alone." Diane F. Halpern \& Milton D. Hakel, Applying the Science of Learning to the University and Beyond: Teaching for Long-Term Retention and Transfer, CHAnGE, July/Aug. 2003, at 39. 
[Vol. 51:1035

they already faced.204 Participants were randomly selected to respond to three of the five follow-up scenarios. Integrity of the cohorts was maintained: those in the pragmatic cohort were asked pragmatic follow-up questions, and those in the ethical cohort were asked ethical follow-up questions. The follow-up questions maintained the language respondents initially faced regarding getting caught or having permission that the respondents initially faced.

The flowchart in Figure 1 illustrates the paths respondents took through Stage 2 of the survey. The next Section discusses some of the survey's limitations. Part IV presents the results.

204 The analog to the original CEO scenario was another CEO scenario involving a successful product. The analog to the original janitor scenario was one involving a security guard. The analog to the original accountant scenario was another accountant scenario in the ethical path, but a scenario involving a junior attorney in the pragmatic path. The analog to the holiday party was a dinner with the insider friend. The analog to the quasi-stranger in the elevator was the same quasi-stranger at an adjacent lane in a bowling alley. 
Figure 1: Paths Through and Variations on Stage 2 Scenarios

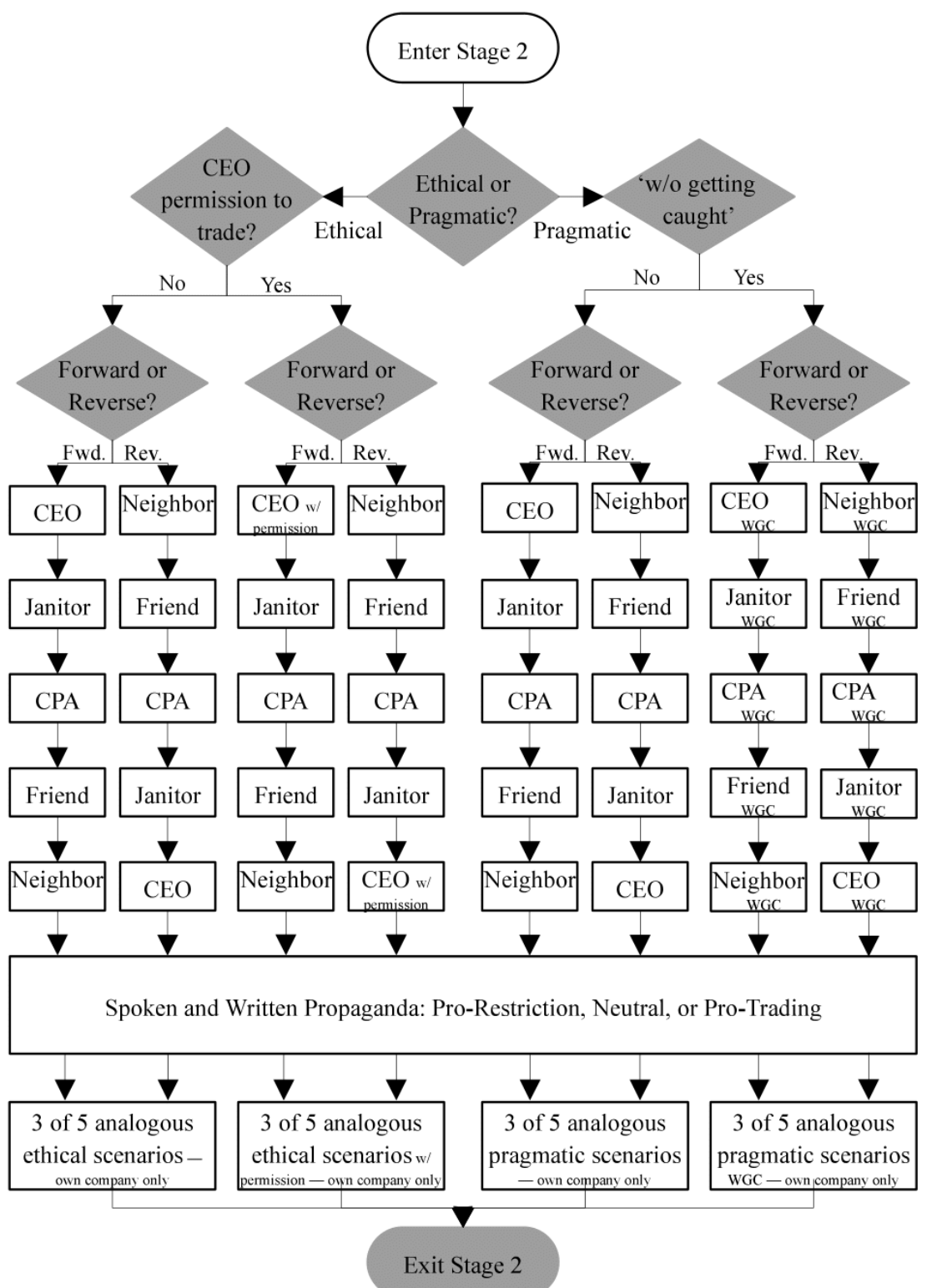




\section{Limitations}

Surveys are, unavoidably, proxies for perfect knowledge about what respondents think. Surveys cannot read minds. Their informative value comes from (1) collecting many answers to maximize the probability that participants' answers reflect what they actually think ${ }^{205}$ and (2) providing a knowledge base that can be used to intuit additional information. ${ }^{206}$ Few claims can truly be proven or falsified. This Section sets forth some of this survey's particular limitations.

\section{Sampling Error}

As with any nonuniversal analysis, the results are subject to sampling error. Sampling error is "the possibility that the sample being tested is not representative of the population from which it is randomly drawn."207 Increasing sample size reduces the magnitude of sampling error. ${ }^{208}$ The survey's sample size of 1,313 produced a margin of error of $\pm 3 \% .209$ In subgroups, which have lower numbers of respondents, the margin of error is higher. The observed results are, nevertheless, the best estimates of the actual values. ${ }^{210}$

\section{Respondent Background Knowledge}

It is difficult to know respondents' background knowledge and what they assumed about survey questions based on that knowledge. For example, it cannot be precisely known whether, when asked about investing in the "stock market," respondents considered holding equities in a retirement account or investing in mutual funds to be

205 See supra note 172 accompanying text.

206 See supra text accompanying notes 182-84; infra Sections IV.D.2-3, IV.E.

207 George A. Mocsary, Statistically Insignificant Deaths: Disclosing Drug Harms to Investors (and Patients) Under SEC Rule 10b-5, 82 GE0. WASH. L. REV. 111, 155 (2013); see David H. Kaye, David A. Freedman \& David H. Kaye, Reference Guide on Statistics, in FED. Jud. CTR., Reference Manual on Sci. Evidence 211, 296 (3d ed. 2011) ("[T] he estimate is likely to differ from the population value because the sample is not a perfect microcosm of the whole.").

208 Freedman \& Kaye, supra note 207, at 246.

209 "Margin of error" is a technical term denoting the range of values lying within a given "confidence interval" around the observed value. RiCHARD D. DE VEAUX ET AL., INTRO STATS 489-92 (3d ed. 2009). For a given sample size, a confidence interval of a certain percentage denotes the percentage of samples taken from the population that will capture the true value. Id. at 489. This study employed the customary confidence interval of $95 \%$ to calculate margins of error. See id. at 490-91. A $\pm 3 \%$ margin of error, therefore, means that one can be $95 \%$ certain that the true proportion of the population that would answer a survey question a certain way is within $3 \%$ of the stated number. See id. at 489-91. The 1,313 does not include respondents who were disqualified for incorrectly answering two screening questions. See supra note 198.

210 See Mocsary, supra note 207, at 128 n.90. 
investing. ${ }^{211}$ Although tradeoffs between survey length ${ }^{212}$ are ever-present, it is often possible, as in this case, to glean indirect insight into facts that could not be discerned directly. ${ }^{213}$

The nuances of insider trading and its interaction with trading markets are complex and technical.214 A layperson may not have an independent basis on which to form opinions about insider trading's pervasiveness, economic effects, and the like. ${ }^{215}$ It is possible, therefore, "that this is an area in which the median voter has delegated her feelings on the matter to her elected officials and to administrative specialists such as SEC investigators." 216

Relatedly, what participants said may not reflect what they thought. It cannot be known for certain whether the respondents meant what they said or said what they meant. There is evidence in the results of Stage 2, for example, that some respondents were applying moral judgments while engaging with the pragmatic scenarios. ${ }^{217}$

But in some situations, like measuring the effect of propaganda herein, the amalgamation of respondents' "priors" 218 merely presents a baseline against which effects can be measured. Even if respondents' biases influenced their initial answers in Stage 2, it is possible to test the effects of propaganda on those views by directly comparing a participant's pre- and post-propaganda answers. ${ }^{219}$ Indeed, this limitation is at least a partial strength because one of the survey's goals was to assess the effect of outside influence on public opinions about insider trading. ${ }^{220}$

211 See Business Week 12/86, supra note 14, at 34; Business Week 8/86, supra note 14, at 74 .

212 See supra text between notes 178 and 179.

213 See infra note 262 and accompanying text (offering a possible reason why answers were different to separate questions asking about reactions to insider trading in individual stocks and the market); infra Sections IV.D.2, IV.D.3, IV.E.1 (discussing findings inferred from direct survey answers).

214 Jeffrey Wagner, Wagner Comments on Kidd et al. SEA 2019 (Nov. 23, 2019) (unpublished conference paper) (on file with authors).

215 See id.

216 Id.

217 See infra Section IV.E.1.ii.

218 "Prior" is short for the statistical terms, "prior knowledge" and "prior probability." See Mocsary, supra note 207, at 140 n.165, 153-54. It represents the amalgamation of an individual's beliefs and experiences that inform the individual's assessment of the probability of a given event happening. See id. More colloquially, the term refers to the beliefs and preconceptions that one brings to a situation.

219 See infra Section IV.E.2.

220 See supra Section III.B.2. 


\section{Respondent Understanding and Question Interpretation}

It can be difficult to tell whether any respondents had trouble understanding the survey. For example, in a nationally representative sample, some respondents may have experienced a language barrier.

One clue that some respondents did not fully understand some questions is that they provided answers that were not directly responsive but nonetheless related to the subject matter. For example, in response to the question, "If you had done your research and found a company that you liked and wanted to invest in, is there anything that might keep you from buying stock in that company?" some participants entered the name of a specific company. ${ }^{221}$ One respondent, who indicated that insider trading in a company's stock would make no difference to his or her likelihood of buying that stock, frankly replied, "I do not know anything about any of this. I am so sorry," to a follow-up question asking whether any amount of insider trading would change his or her mind.

But such answers were rare enough that their effects were likely trivialized by the study's large sample size.222 In addition, because measuring the malleability of the public's views about insider trading was an important objective, the survey attempted to partially mitigate respondent misunderstanding of the arguments for and against insider trading by adding a professionally read and recorded audio clip of the arguments to the survey's written text.223

Even in the absence of misunderstanding, participants may have interpreted questions differently. Without asking overly detailed questions that may have been difficult for some respondents to understand, it is impossible to know whether respondents perceived absolute or relative increases in the pervasiveness of insider trading as

221 Appendix A, at 1, available at http://dx.doi.org/10.15786/20.500.11919/7122. For example, Apple, Google, Facebook, and Morgan Stanley. Although rare, some questions had stranger answers. For example, respondents indicating that they would be less willing to buy a company's stock if insiders were trading in it were asked, "[w]hat is it about insider trading that would make you less willing to buy?" Three respondents answered, "[p]ersonal information," "[a] small locally owned company nothing a large national company the too many finger to get an equal slice," and "my privacy being stolen."

Some answers, however, suggested that respondents were thinking more deeply about a question. For example, when asked why they would be more likely to trade in a firm's stock in the presence of insider trading, two participants responded, "my children" and "[t]his game can be beat up." The responses suggest that these participants believed that insider trading in the stock would somehow benefit them financially and that they would trade for the benefit of their children or themselves.

222 See supra text accompanying notes 172-73; note 209 and accompanying text.

223 See supra note 203 and accompanying text. 
compared to perceptions in 1986.224 If the latter, it cannot be known along which measure-market size, economy size, population, etc.-respondents were mentally comparing insider trading frequencies. More simply, and of meaningful research value, the belief that insider trading is more common today may be a result of greater exposure to public chatter about the topic. ${ }^{225}$

\section{Results Interpretation}

Although employing objective questions can reduce the potential for researcher subjectivity to skew results, it does not entirely eliminate interpretational uncertainty. ${ }^{226}$ The same can be said of employing law students to code subjective questions. ${ }^{227}$ Although "there is good reason to believe that law students are capable of accurately coding a wide range of variables," 228 student coders may lack the expertise necessary reliably to code more nuanced responses. 229

Interpreting objective questions is open to some subjectivity when analyzing results beyond reporting the hard data. This includes how to interpret nonresponsive answers and nonanswers. ${ }^{230}$ The next Part, therefore, while presenting the survey's key findings, offers only educated speculation on why certain answers were given, leaving a detailed examination of that topic for a future work. ${ }^{231}$

\section{Public ATtitudes Toward INSIDER TRAding}

This Part begins with a comparison of this survey's results with the famous pair of 1986 Business Week studies in Section A. It then summarizes the survey's findings across four broad dimensions. Section B discusses results speaking to the public's views about insider trading's pervasiveness. Section C covers the survey's implications about the effect of insider trading on market confidence. Section D

224 See Wagner, supra note 214; infra Table 1.

225 Research on the availability heuristic shows that decision-makers tend to assign heightened probabilities to the occurrence of events that they have heard about more recently and frequently. Amos Tversky \& Daniel Kahneman, Availability: A Heuristic for Judging Frequency and Probability, 5 Cognitive Psychol. 207, 230 (1973).

226 See supra Sections III.B.1, III.B.2.

227 See supra note 201 and accompanying text.

228 Ruben \& Blocher, supra note 180, at 1464 (citing Charles A. Johnson, Content-Analytic Techniques and Judicial Research, 15 AM. PoL. Q. 169, 182-96 (1987)).

229 Hall \& Wright, supra note 201, at 111.

230 Nonresponse in Social Science Surveys: A Research Agenda (Roger Tourngeau \& Thomas J. Plewes eds., 2013).

231 The Authors intend to survey and flesh out the why in an upcoming article. See infra Part V. Indeed, this survey informs the topics about which why questions should be asked. See supra text accompanying note 147. 
reports respondents' stated views about the morality of, and appropriate punishment for, insider trading. It couples this descriptive account with analyses of individual respondents' answers to offer deeper insight into the strength of the expressed views. Section E describes participants' expressed views about the propriety of insider trading in various situations, and the effect on those views of exposing respondents to various items of insider trading propaganda.

The survey aimed to achieve a census-representative sample across gender, ${ }^{232}$ race, ${ }^{233}$ age, education, income, ${ }^{234}$ and citizenship. It also captured views by political ideology and trading status. There were no significant differences in views across the mainstream political spectrum. The results suggest that insider trading is simply not a political issue. 235

Each Section relates the key findings at the survey level and notes stand-out findings at the demographic-cohort level. The survey, its raw data, summary spreadsheets, and a readme file are available online at Mountain Scholar with a unique Digital Object Identifier. ${ }^{236}$

232 Participants were given the option to identify as a gender other than male or female. Three respondents so identified, which was insufficient to draw meaningful conclusions.

233 The broad racial categories employed by the survey were adapted from the U.S. Census. They are standard among survey instruments. By their nature as broad categories, they are poor representations of the actual lived experiences of respondents. Little can or should be assumed about individual participants based on the various socioeconomic groups-racial or otherwise-with which they most strongly identified. The number of respondents identifying as Native American (13) or Other (22) was small, reducing those results' reliability.

234 Categories for age, education, and income were standard survey categories. Age categories were: 18-24; 25-34; 35-44; 45-54; 55-64; 65-74; and 75+. Education categories were: None; Some High School; High School Diploma or GED; Some College; Technical or Vocational Degree; Associates Degree; Bachelor's Degree; Master's Degree; Professional Degree; and Doctoral Degree. Income categories were less than $\$ 25,000$; $\$ 25,000-\$ 34,999 ; \$ 35,000-\$ 49,999 ; \$ 50,000-\$ 74,999 ; \$ 75,000-\$ 99,999 ; \$ 100,000$ $\$ 149,999 ; \$ 150,000-\$ 199,999$; and more than $\$ 200,000$.

235 This result held throughout the survey, with the only significant difference between ideological categories arising among participants identifying as socialist, communist, or libertarian. There was no significant difference between the remaining categories (very conservative, conservative, moderate, liberal, and very liberal), indicating that insider trading views are not ideology driven. Further, the number of respondents identifying as socialist (21), communist (11), or libertarian (17) was small, reducing those results' reliability.

236 John P. Anderson, Jeremy L. Kidd \& George A. Mocsary, Public Perceptions of Insider Trading, MOUNTAIN SCHOLAR (2020), http://dx.doi.org/10.15786/ 20.500.11919/7122. 


\section{A. Comparisons to 1986}

Given the social, political, financial, and technological changes since the famous Business Week surveys of August and December 1986,237 it is valuable, as a threshold matter, comparing those surveys' results to those obtained in this study. The surveys overlapped on the three key points, shown in Table 1, which are referenced throughout this Article.

Table 1: Comparisons to $1986^{238}$

\begin{tabular}{|c|c|c|c|}
\hline & $8 / 86$ & $12 / 86$ & $4 / 19$ \\
\hline Insider trading is common or very common & $63 \%$ & $67 \%$ & $80 \%$ \\
\hline Insider trading should be illegal & $52 \%$ & $66 \%$ & $66 \%$ \\
\hline Would trade on a tip & $53 \%$ & $55 \%$ & $45 \%$ \\
\hline
\end{tabular}

The August 1986 results were collected before the SEC announced its famous enforcement action against Ivan Boesky, ${ }^{239}$ and the December 1986 results after that.240 Although insider trading actions were relatively rare before 1986, the number of civil and criminal actions has since increased markedly, ${ }^{241}$ with a corresponding increase in public discussion of the topic.

\section{B. Pervasiveness}

The public believes that insider trading is more pervasive compared to 1986. After the Boesky scandal, 67 percent of respondents believed that it was common, whereas in 2019,80 percent believed that it was common or very common. ${ }^{242}$ Table 2 shows overall opinions

237 See supra text accompanying notes 168-69; Ravikumar, supra note 169; Business Week 12/86, supra note 14; Business Week 8/86, supra note 14.

238 The questions have been paraphrased. See Business Week 8/86, supra note 14, at 74, Business Week 12/86, supra note 14, at 34, and Appendix A, available at http://dx.doi.org/10.15786/20.500.11919/7122, for the questions as administered. The 1961 Harvard Business Review study asking executives whether they would trade on information obtained at a board meeting reported that 42 percent responded that they would, 14 percent would have told a friend, 2 percent would have told a broker, and 56 percent would have done nothing. See Baumhart, supra note 14, at 16.

239 Stephen R. Martin, Ivan Boesky: American Banker, EncYc. BRITANNICA, https://www.britannica.com/biography/Ivan-Boesky (last visited Jan. 31, 2021).

240 See generally James B. Stewart \& Daniel Hertzberg, Spreading Scandal: Fall of Ivan F. Boesky Leads to Broader Probe of Insider Information, WALL ST. J., Nov. 17, 1986, at 1.

241 See Stephen J. Crimmins, Insider Trading: Where is the Line?, 2013 Colum. Bus. L. REv. 330, 349 (2013).

242 See supra Table 1. The December 1986 survey reported the percentage of respondents expressing the belief that insider trading was "Common." Business Week 
about the pervasiveness of insider trading at the survey level, and those broken down by gender, race, and trading status.

Table 2: Answers to "How common do you think insider trading is?"

\begin{tabular}{lrrrc} 
& Very Common & Common & \multicolumn{1}{l}{ Rare } & Very Rare \\
Overall & $25.4 \%$ & $55.0 \%$ & $15.0 \%$ & $4.6 \%$ \\
Gender & & & & \\
Female & $24.0 \%$ & $57.0 \%$ & $14.4 \%$ & $4.5 \%$ \\
Male & $26.8 \%$ & $52.7 \%$ & $15.9 \%$ & $4.6 \%$ \\
Race & & & & \\
Asian & $25.8 \%$ & $51.5 \%$ & $18.2 \%$ & $4.5 \%$ \\
Black & $41.6 \%$ & $38.8 \%$ & $15.2 \%$ & $4.5 \%$ \\
Latinx & $25.3 \%$ & $55.4 \%$ & $14.5 \%$ & $4.8 \%$ \\
Native Am. & $25.0 \%$ & $58.3 \%$ & $0.0 \%$ & $16.7 \%$ \\
White & $22.3 \%$ & $58.3 \%$ & $15.1 \%$ & $4.3 \%$ \\
Other & $22.7 \%$ & $54.6 \%$ & $13.6 \%$ & $9.1 \%$ \\
Trading Status & & & & \\
Invest & $30.5 \%$ & $52.1 \%$ & $14.4 \%$ & $3.0 \%$ \\
Abstain & $21.5 \%$ & $56.9 \%$ & $15.9 \%$ & $5.7 \%$
\end{tabular}

The data revealed that general opinions regarding insider trading's pervasiveness-the sum of "common" and "very common" responses-were likely more relevant than participants' attempts to distinguish between "common" and "very common" or between "rare" and "very rare." Men were slightly more likely to say insider trading is very common, for example, but there were no significant differences between genders when "common" and "very common" answers were combined. Similarly, Black respondents were more likely to answer that insider trading is "very common" but did not differ significantly in their overall views of its pervasiveness.

Investors were more likely than abstainers to view insider trading as pervasive. If insider trading's perceived pervasiveness undermines market confidence, one would expect that those who invest would be

12/86, supra note 14 , at 34 . The August 1986 survey reported the percentage of respondents expressing the belief that insider trading was "Very or somewhat common." Business Week 8/86, supra note 14 , at 74 . 
less likely to believe that insider trading is common or very common. Slight trends emerged based on age, income, and educational attainment: older, wealthier, and more educated participants were less likely to view insider trading as pervasive.

\section{Market Confidence}

Data on public perceptions of insider trading's frequency are, perhaps, less useful than on whether those perceptions translate into reluctance to trade, as the market-confidence theory predicts. ${ }^{243}$ The results are mixed.

54.3 percent of respondents said that they do not invest in the stock market, which is a significant decrease from the 80.4 percent who believed that insider trading is common or very common, suggesting that insider trading does not deter a large portion of would-be investors from market participation. Of the 25.4 percent of respondents who believed that insider trading was very common, 13.3 percent-over half-nonetheless invest. ${ }^{244}$ In a strong form of the market-confidence theory, the group answering that insider trading was very common should be the group least likely to invest in stocks. Of the 55.0 percent of participants who believed that insider trading was common, 22.2 percent ${ }^{245}$ nonetheless invest. Overall, of the 80.4 percent believing that insider trading was common or very common, 35.5 percent-less than half ${ }^{246}$-invest; of the 19.6 percent who believe that insider trading is rare or very rare, 7.5 percent-significantly less than half ${ }^{247}$-invest.

There was no trend in trading activity between age groups. There were substantial differences between cohorts, with non-investors ranging from 47.6 percent for 65 - to 74 -year-olds, to 59.0 percent for those 75 or older, but no discernable pattern. Further investigation might reveal some unseen correlation, such as market downturns during formative periods in the lives of individuals in cohorts where trading activity is low. Market participation rose steadily with education and income, as might be expected.

Some of the individuals who invest may do so reluctantly or to a lesser degree, preferring to invest excess income in what they believe to be a substandard market rather than forgo the higher returns that

243 See supra Section II.B.3.

244 That is, 52.1 percent of those who responded that insider trading was very common nevertheless invest.

245 That is, 40.4 percent.

24644.1 percent, to be precise.

24738.1 percent, to be precise. 
[Vol. 51:1035

equity markets nonetheless offer. ${ }^{248}$ This would support a less-robust form of the market-confidence theory. The survey addressed, at least partially, this possibility in two ways. First, it asked respondents, via an open-ended question, whether anything might keep them from investing in a company that they researched and liked. Table 3 presents the results.

248 See infra notes 259-62 and accompanying text. 
Table 3: Answers to "If you had done your research and found a company that you liked and wanted to invest in, is there anything that might keep you from buying stock in that company?"249

No

Discomfort with this trade

Company's bad financial reputation

Company's bad moral/ethical reputation

Company is a bad investment

Company's stock is unstable

Other

Insider trading at the company

Lack of capital to invest

Discomfort trading generally

Investing is too risky

Don't trust financial markets

Not interested in trading

Don't know how to trade

Overall market trends

Don't know

Yes

Trading is too costly (stock price, fees)

Advice from family, friends, or financial advisors
$30.6 \%$

$\mathbf{2 1 . 1 \%}$

$9.9 \%$

$5.6 \%$

$2.8 \%$

$1.4 \%$

$1.1 \%$

$0.4 \%$

$11.3 \%$

$7.5 \%$

$3.9 \%$

$1.6 \%$

$0.9 \%$

$0.8 \%$

$0.8 \%$

$6.3 \%$

$4.7 \%$

$4.0 \%$

$1.8 \%$

Notably, despite knowing that the study was about insider trading, only 0.4 percent indicated that insider trading in the company would deter them from investing in that company. Six times as many individuals, when asked what about insider trading in the stock of a company that they were researching would make them less willing to buy, said that it was fear of being innocently caught up in a regulatory action. ${ }^{250}$ The chilling effect of insider trading enforcement may thus

24912.8 percent of answers were blank or nonresponsive.

250 See infra Table 4, which shows that 48.2 percent of respondents would be less willing to buy stock in a company if they thought that a small number of people were trading in its stock based on inside information. See also infra Table 5, which shows that 4.9 percent of that 48.2 percent would be less willing to buy stock in that company for 
have a greater impact on market participation than does the activity that it seeks to prevent.

Second, participants were asked two separate questions directly positing the presence of insider trading and their willingness to trade. The first asked respondents whether they would be more or less willing to trade in a company's stock if they believed that there was a small amount of insider trading in that stock. The second asked participants whether they would be more or less willing to engage in trading in the stock market generally if they knew that insider trading was common in that same broad market. Summary and outlier answers to both questions are presented in Table 4.

fear that innocent investors might be implicated in a regulatory action. (48.2)(0.049) = 2.4 percent. This 2.4 percent is six times as large as 0.4 percent. This figure is slightly higher, because of rounding, than the actual value of 5.8 times as many, which is obtained by dividing the twenty-nine respondents who indicated fear of innocent implication by the five who would be deterred from investing by insider trading at a company of interest. 
Table 4: Willingness to Trade in the Presence of Insider Trading

"If you thought that a small number of people were trading on inside information concerning a company you have been researching, would it make you more likely to buy stock in that company, less likely, or make

no difference?"

$\begin{array}{lcccc} & \text { Less Likely } & \text { No Difference } & \text { More Likely } & \begin{array}{l}\Delta \text { Less Likely vs. } \\ \text { Market }\end{array} \text { Ov1 } \\ \text { Overall } & 48.2 \% & 34.3 \% & 17.5 \% & +4.9 \% \\ \text { Fender } & & & & \\ \text { Male } & 50.3 \% & 31.4 \% & 18.3 \% & +3.4 \% \\ \text { Race } & & & & \\ \text { Asian } & 45.5 \% & 28.8 \% & 25.8 \% & +1.5 \% \\ \text { Black } & 37.1 \% & 30.9 \% & 32.0 \% & +9.0 \% \\ \text { Latinx } & 42.2 \% & 37.4 \% & 20.5 \% & +2.4 \% \\ \text { Native Am. } & 50.0 \% & 16.7 \% & 33.3 \% & -16.7 \% \\ \text { White } & 51.4 \% & 35.0 \% & 13.6 \% & +4.9 \% \\ \text { Other } & 40.9 \% & 50.0 \% & 9.1 \% \% & +4.6 \% \\ \text { Trading Status } & & & & \\ \text { Invest } & 50.3 \% & 24.4 \% & 25.3 \% & +8.9 \% \\ \text { Abstain } & 47.1 \% & 42.0 \% & 11.0 \% & +2.5 \%\end{array}$

251 This column represents the difference between (1) the percentage of respondents' answering that they would be less likely to trade in a company's stock if they knew that a small number of people were trading on it based on inside information, and (2) the percentage of respondents' answering that they would be less likely to invest in the stock market if they knew that insider trading was common in that market. 
"If you knew insider trading was common in the stock market, would you be more likely to invest, less likely, or would it make no difference?"

$\begin{array}{lcccc} & \text { Less Likely } & \text { No Difference } & \text { More Likely } & \begin{array}{c}\Delta \text { Less Likely vs. } \\ \text { Company } 252\end{array} \\ \text { Overall } & 43.3 \% & 40.6 \% & 14.9 \% & -4.9 \% \\ \text { Gender } & & & & \\ \text { Female } & 40.2 \% & 42.1 \% & 16.7 \% & -6.5 \% \\ \text { Male } & 47.0 \% & 39.3 \% & 12.5 \% & -3.4 \% \\ \text { Race } & & & & \\ \text { Asian } & 43.9 \% & 36.4 \% & 19.7 \% & -1.5 \% \\ \text { Black } & 28.1 \% & 39.3 \% & 32.6 \% & -9.0 \% \\ \text { Latinx } & 39.8 \% & 34.9 \% & 25.3 \% & -2.4 \% \\ \text { Native Am. } & 66.7 \% & 33.3 \% & 0.0 \% & +16.7 \% \\ \text { White } & 46.5 \% & 41.7 \% & 10.3 \% & -4.9 \% \\ \text { Other } & 36.4 \% & 50.0 \% & 9.1 \% & -4.6 \% \\ \text { Trading Status } & & & & -8.9 \% \\ \text { Invest } & 41.3 \% & 38.4 \% & 19.1 \% & -2.5 \% \\ \text { Abstain } & 44.5 \% & 42.7 \% & 11.5 \% & \end{array}$

Overall, fewer than half of the survey's participants said that they would be less likely to trade in a given stock if they believed that insider trading was occurring in that stock, and even fewer said that "common" insider trading in the broader stock market would deter them from trading. 51.8 percent responded that their awareness of limited insider trading (insider trading by a small number of people) in a stock of interest would either not affect their trading in that stock or make them more likely to invest in it. Similarly, 55.5 percent responded that knowledge of common insider trading would either make them more likely to invest or make no difference. This, again, offers limited support for the market-confidence theory, in that some of the 48.2 and 43.3 percent of respondents who were less likely to invest in a stock of

252 This column represents the difference between (1) the percentage of respondents' answering that they would be less likely to invest in the stock market if they knew that insider trading was common in that market and (2) the percentage of respondents' answering that they would be less likely to trade in a company's stock if they knew that a small number of people were trading on it based on inside information. 
interest or the overall market, respectively, might also be abstaining altogether because of insider trading. ${ }^{253}$

Men were slightly more likely to be concerned about insider trading than women in both scenarios. White respondents were more likely to be concerned than all minorities in the company-specific scenario, and more than all but Native American participants in the broad-market scenario. Black participants were least concerned with insider trading. Their responses were most evenly split between less likely, indifferent, and more likely in the company-specific scenario, and they were least likely to avoid trading when insider trading is common in the broader market scenario.

This directly expressed aversion 254 to investing because of insider trading rises generally, though not uniformly, with age in both the company-specific and broad-market scenarios, as shown in Figure 2. It may be the result of longer exposure to public chatter-including much-hyped prosecutions and convictions of figures like Ivan Boesky and Raj Rajaratnam - that influences views and induces fear..$^{255}$

254 As compared to a discerned aversion. See supra notes 243-46 and accompanying text.

255 See Elvis Picardo, How the SEC Tracks Insider Trading, InVESTOPEDIA, https://www.investopedia.com/articles/investing/021815/how-sec-tracks-insidertrading.asp (last updated June 25, 2019); supra notes 239, 42 and accompanying text; see infra text accompanying note 271; see supra note 225 and accompanying text. 
Figure 2: Percentage of Respondents Less Likely to Invest Because of Insider Trading, by Age

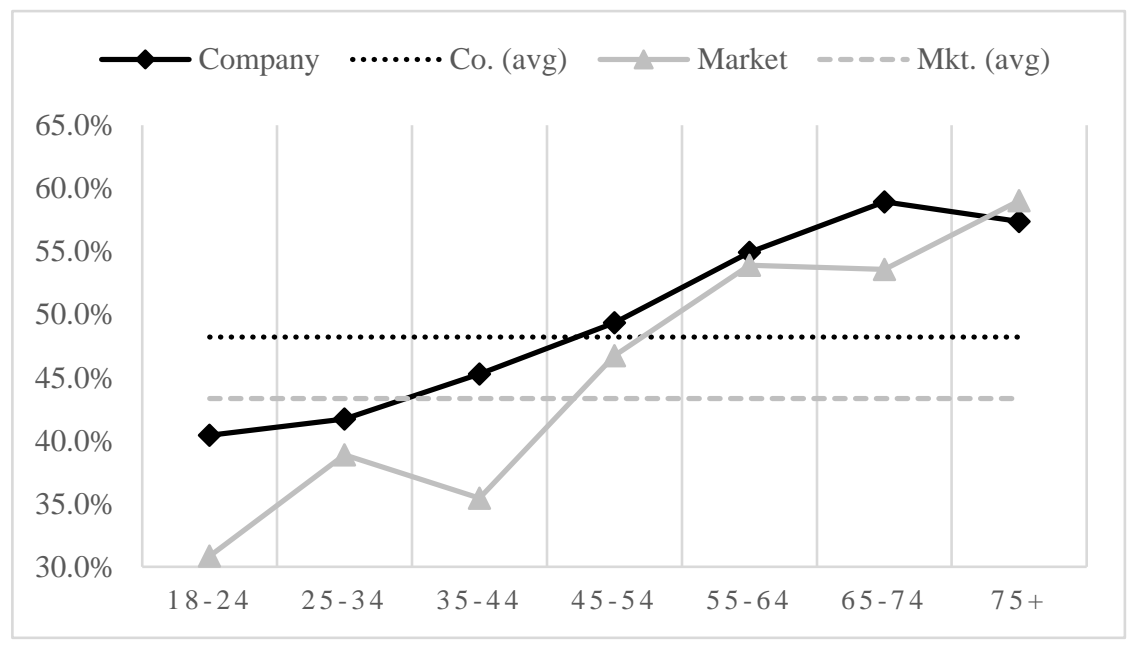

Expressed aversion to investing because of insider trading rises somewhat with income (Figure 3) and education (Figure 4) in the company-specific scenario, but those relationships weaken substantially or disappear when the concern is insider trading in the broader market. ${ }^{256}$ Income is traditionally correlated with age and education..$^{257}$

256 The upward trends might be exaggerated by the Some High School category (with only forty-six respondents), which was an outlier on the low end.

257 See Boshara et al., The Demographics of Wealth: How Age, Education and Race Separate Thrivers from Strugglers in Today's Economy, Fed. Reserve Bank of St. Louis 17 (2015). 
Figure 3: Percentage of Respondents Less Willing to Invest Because of Insider Trading, by Income

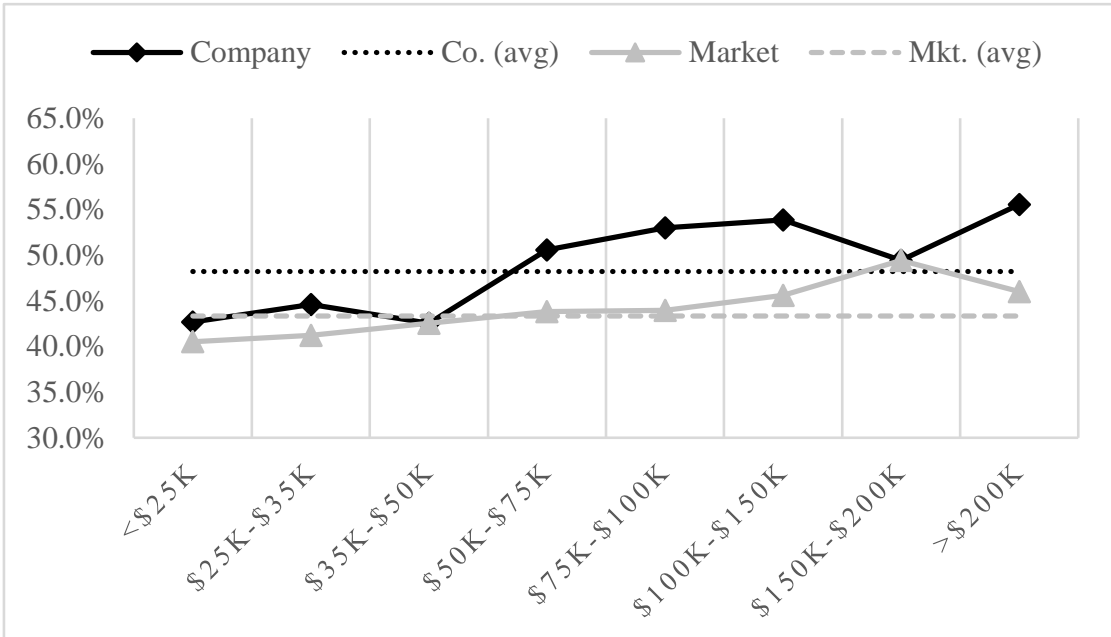

Figure 4: Percentage of Respondents Less Willing to Invest Because of Insider Trading, by Education

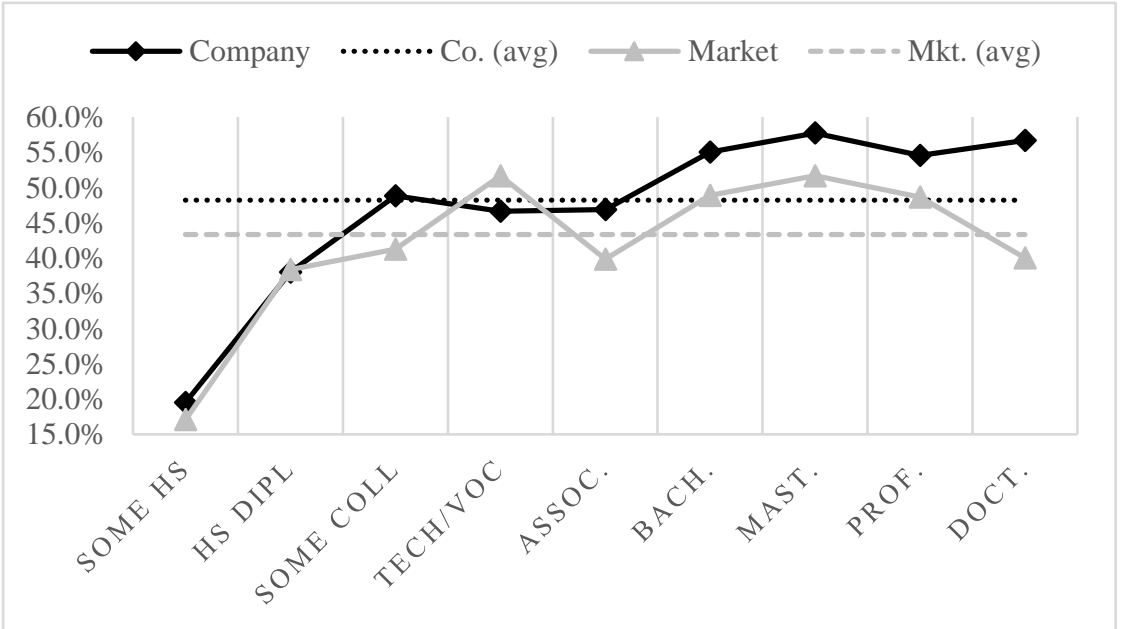

Just over half of active traders would be less likely to trade in the company scenario and fewer than half would be less likely to trade in the market scenario knowing that insider trading is taking place. A review of individual responses shows that a sizable number of participants who indicated a lower willingness to trade in the presence of insider trading also indicated that they are already not trading. There 
are two explanations, each in the nature of a corner solution, 258 that tell a different story about the market-confidence theory.

Most favorably to the market-confidence theory, it is theoretically possible that all participants indicating that they would be discouraged from investing because of insider trading actually do not invest because of a belief that insider trading is taking place. In this case, the percentages of respondents who would be less likely to invest in the stock market in the presence of insider trading are 48.2 and 43.3 percent, as reported in Table 4.

Least favorably to the market-confidence theory, nontraders who indicated that they would be less likely to invest in the presence of insider trading may not be trading anyway. If that is the case, they can be discounted in determining the theory's strength, and the actual percentage of respondents whom insider trading would deter drops to 21.5 and 17.7 percent for the company-specific and broad-market scenarios.

Because some might be less likely to invest due to insider trading but invest anyway, ${ }^{259}$ and some might be less likely to invest but not invest for other reasons, the actual percentage of individuals who would be deterred from investing because of insider trading is likely to be somewhere between these extreme figures. ${ }^{260}$

Supporting the market-confidence theory, it is possible that the difference between the single-company and broad-market views indicates a desire to diversify away insider trading's effects. It may be that survey participants perceived insider trading to be "but one friction in the decision to be active in the equity markets."261 To manage their perceived informational disadvantage vis-à-vis insiders while capturing

258 A corner solution is one where a single factor dominates. See WALTER Nicholson, Microeconomic Theory: Basic Principles and Extensions 103-05 (7th ed. 1998).

259 See supra text accompanying note 248; infra text accompanying note 262.

260 One estimate of the actual, in-between percentage for the broad-market scenario is 38.7 percent less likely to invest because of insider trading. This figure is arrived at by, at the individual-response level, subtracting from the percentage of those who indicated a lower likelihood of investing in the presence of "common" insider trading, supra Table 4: Willingness to Trade in the Presence of Insider Trading, those who indicated both that they believed insider trading to be very rare or rare and that they did not invest, see supra notes 243-46. That is, they would not be dissuaded from investing because insider trading is merely very rare or rare, but nonetheless do not trade, suggesting that something other than insider trading is keeping them out of the market. On the other hand, it may be that any amount of insider trading would keep them out of the market.

Performing the same calculation for the company-specific scenario yields 43.1 percent. This number is less reliable, however, because it compares a company-specific scenario to broad-market participation. Cf. supra notes 243-46.

261 Wagner, supra note 214. 
the still-higher returns that stock markets offer, individuals may favor investing in the broad market over an individual stock. ${ }^{262}$

Participants indicating a lower willingness to invest in a company whose stock was being traded based on inside information were asked what it was about insider trading that changed their willingness to buy. The responses are presented in Table 5.

\section{Table 5: Answers to "What is it about insider trading that would make} you less willing to buy?"263

Unfair advantage/imperfect information

It is immoral and unethical

It is illegal

It increases price instability and uncertainty

It means the company is not a good investment

It means prices are not accurate reflections of firm value

It attracts the attention of regulators and innocent investors might be implicated

Cannot trust the company

It increases corruption and can ruin the corporation
$25.0 \%$

$21.1 \%$

$15.2 \%$

$7.3 \%$

$6.6 \%$

$5.6 \%$

$4.9 \%$

$4.4 \%$

$4.1 \%$

Of these responses, 48.6 percent focused on the effect that insider trading would have on the short- or long-run value of the respondent's would-be investment. ${ }^{264}$ Of this 48.6 percent, 37.9 percent focused on clearly confidence-related factors, 4.1 percent focused on information-revealing factors related to trust issues at the company, and 6.6 percent focused on the purely information-revealing factor that something was wrong at the company. ${ }^{265}$ The trust-related category

262 See id.; supra text accompanying notes 248,259 . In other words, diversification may be seen as a tool to reduce perceived insider trading risk just as it may be used to reduce other risk. If this is the case, it suggests that a meaningful number of respondents may have understood that participating in pooled-account investing involves investing in the stock market. See supra text accompanying notes 176-77, 211.

26310.3 percent of answers were blank or nonresponsive.

264 Included in this total are the answers indicating a belief that insider trading: provides an unfair advantage to the insider or imperfect information in the market (25 percent); increases price instability (7.3 percent); means that the company is not a good investment (6.6 percent); means that prices are not an accurate reflection of market value ( 5.6 percent); and increases corruption and can ruin the corporation ( 4.1 percent).

265 The confidence-related factors are the sum of the 25-percent, 7.3-percent, and 5.6-percent lines in Table 5. The trust-related factor is the 4.1-percent line. The purely information-revealing factor is the 6.6-percent line. 
lends some support to the market-confidence hypothesis, with the caveat that it should be viewed in the context of the current regulatory environment in which insider trading is illegal. Even potential investors who consider insider trading to be nonproblematic may consider it a sign of untrustworthiness to engage in illegal activity. ${ }^{266}$

21.1 percent said that they would be less willing to buy because insider trading is immoral or unethical, and 15.2 percent said that their decreased willingness was driven by insider trading's illegality, for a total of 36.3 percent. These answers suggest several possibilities. Respondents may not have liked the feeling of getting their hands dirty by being potentially involved, for better or worse, in unethical or illegal activity. Relatedly, it may be a proxy for one of the other answers, like the 4.9 percent expressing fear that insider trading by others would attract regulators who would implicate innocent investors in the crime. They may be non-sequitur answers, perhaps suggesting that the respondents did not understand the question, since the respondents-the would-be investors-were not the ones whom the question posited were engaging in the insider trading and thus the perceived misbehavior.

The 17.5 percent responding that they would be more likely to invest in a company where insiders were trading were invited to explain why the presence of insider trading would make them more willing to buy that stock. Table 6 presents the results.

266 Participants presumably assumed that the company, as an entity, either knew about its insiders' trading, did not adequately police its insiders, or otherwise did not do enough to prevent the illegal activity. They may view the trust-related aspects of insider trading differently under an issuer-licensing regulatory regime. See infra text accompanying note 308 . 
Table 6: Reasons for being more willing to buy stock in a company if a small number of people were trading on inside information ${ }^{267}$

$\begin{array}{lc}\text { Insider trading shows corporate confidence } & 31.4 \% \\ \text { Opportunity to make a profit } & 13.3 \% \\ \text { Personally like the corporation } & 8.0 \% \\ \text { Insider trading reveals information about the corporation } & 2.2 \% \\ \text { Don't know, unsure } & 7.1 \%\end{array}$

Although more than one-third of respondents declined to answer, 33.6 percent gave purely information-revealing factors that the company was a good investment. Of this 33.6 percent, 31.4 percent said that insider trading shows corporate confidence in the company, and 2.2 percent responded more generally that the existence of insider trading reveals trade-worthy information about the corporation. 13.3 percent of participants indicated that insider trading by others revealed an opportunity to make a profit, suggesting either that they believed that the practice revealed information, or that it could actively help them realize abnormal returns. The remaining 8 percent seemed to say either that they are unconcerned with insider trading, or that the presence of insider trading is a catalyst ${ }^{268}$ that confirms their positive intuitions about a company.

More than one-third of participants gave nonresponsive answers. Although interpreting nonresponses is subject to uncertainty, ${ }^{269}$ it is worth cautiously considering them here given their high number (including when combined with the "don't know/unsure" responses). This group may have an inarticulable sense that insider trading somehow benefits them.

\section{Moral Views}

The survey next explored respondents' intuitions about insider trading's morality. It directly asked participants their views and provided a base from which more nuanced analyses could be performed. The next Section reports respondents' stated moral views, and the one that follows it describes those which they may have revealed.

\footnotetext{
26738.1 percent of answers were blank or nonresponsive.

268 See supra text accompanying notes 261-62.

269 See Nonresponse in Social Science Surveys: A Research AgEnda, supra note 230, at $40-41$.
} 


\section{Stated Moral Positions}

Study participants were asked three direct questions informing the morality inquiry: (1) whether they would trade on inside information if it came into their possession; (2) whether they believed that insider trading was morally wrong; and (3) whether they believed that insider trading should be illegal. Table 7 lays out the results.

Table 7: Stated Moral Positions ${ }^{270}$

\begin{tabular}{|c|c|c|c|c|c|c|}
\hline & \multicolumn{2}{|c|}{$\begin{array}{l}\text { Would you trade } \\
\text { based on inside info? }\end{array}$} & \multicolumn{2}{|c|}{$\begin{array}{l}\text { Is insider trading } \\
\text { morally wrong? }\end{array}$} & \multicolumn{2}{|c|}{$\begin{array}{l}\text { Should insider } \\
\text { trading be illegal? }\end{array}$} \\
\hline & Yes & No & Yes & No & Yes & No \\
\hline Overall & $44.9 \%$ & $55.1 \%$ & $62.8 \%$ & $35.5 \%$ & $66.7 \%$ & $33.3 \%$ \\
\hline \multicolumn{7}{|l|}{ Gender } \\
\hline Female & $45.9 \%$ & $54.1 \%$ & $59.4 \%$ & $39.3 \%$ & $62.5 \%$ & $37.5 \%$ \\
\hline Male & $43.6 \%$ & $56.4 \%$ & $66.7 \%$ & $31.2 \%$ & $71.5 \%$ & $28.5 \%$ \\
\hline \multicolumn{7}{|l|}{ Race } \\
\hline Asian & $56.1 \%$ & $43.9 \%$ & $56.1 \%$ & $42.4 \%$ & $62.1 \%$ & $37.9 \%$ \\
\hline Black & $59.0 \%$ & $41.0 \%$ & $43.3 \%$ & $55.1 \%$ & $45.5 \%$ & $54.5 \%$ \\
\hline Latinx & $61.5 \%$ & $38.6 \%$ & $45.8 \%$ & $51.8 \%$ & $48.2 \%$ & $51.8 \%$ \\
\hline Native Am. & $66.7 \%$ & $33.3 \%$ & $58.3 \%$ & $41.7 \%$ & $58.3 \%$ & $41.7 \%$ \\
\hline White & $39.7 \%$ & $60.2 \%$ & $68.6 \%$ & $29.7 \%$ & $72.6 \%$ & $27.4 \%$ \\
\hline Other & $40.9 \%$ & $59.1 \%$ & $59.1 \%$ & $40.9 \%$ & $72.7 \%$ & $27.3 \%$ \\
\hline \multicolumn{7}{|c|}{ Trading Status } \\
\hline Invest & $51.3 \%$ & $48.7 \%$ & $66.5 \%$ & $31.6 \%$ & $71.3 \%$ & $28.7 \%$ \\
\hline Abstain & $40.3 \%$ & $59.7 \%$ & $59.3 \%$ & $39.3 \%$ & $62.4 \%$ & $37.6 \%$ \\
\hline
\end{tabular}

Although 62.8 and 66.7 percent of respondents said that insider trading was morally wrong and should be illegal, 44.9 percent nevertheless stated that they would trade based on inside information. Stated differently, although most participants said that they would not trade on inside information, higher percentages of respondents indicated that insider trading was morally wrong or should be illegal.

270 See Appendix A, available at http://dx.doi.org/10.15786/20.500.11919/7122, for the survey questions as administered. 
Women were more tolerant of insider trading than men, with fewer calling it morally wrong, fewer believing that it should be illegal, and more who would be willing to engage in it. Participants of underrepresented races were substantially more tolerant of the practice than were White participants. Notably, absolute majorities of Asian, Black, and Latinx respondents indicated a willingness to trade based on inside information.

The young were far less likely to believe that insider trading is morally wrong or that it should be illegal, and a large majority would trade on nonpublic information if given the opportunity, as shown in Figure 5. This may be the result of shorter exposure to hostile public discourse on the topic ${ }^{271}$ or less caution on the part of the young. 272

Figure 5: Acceptance of Insider Trading by Age

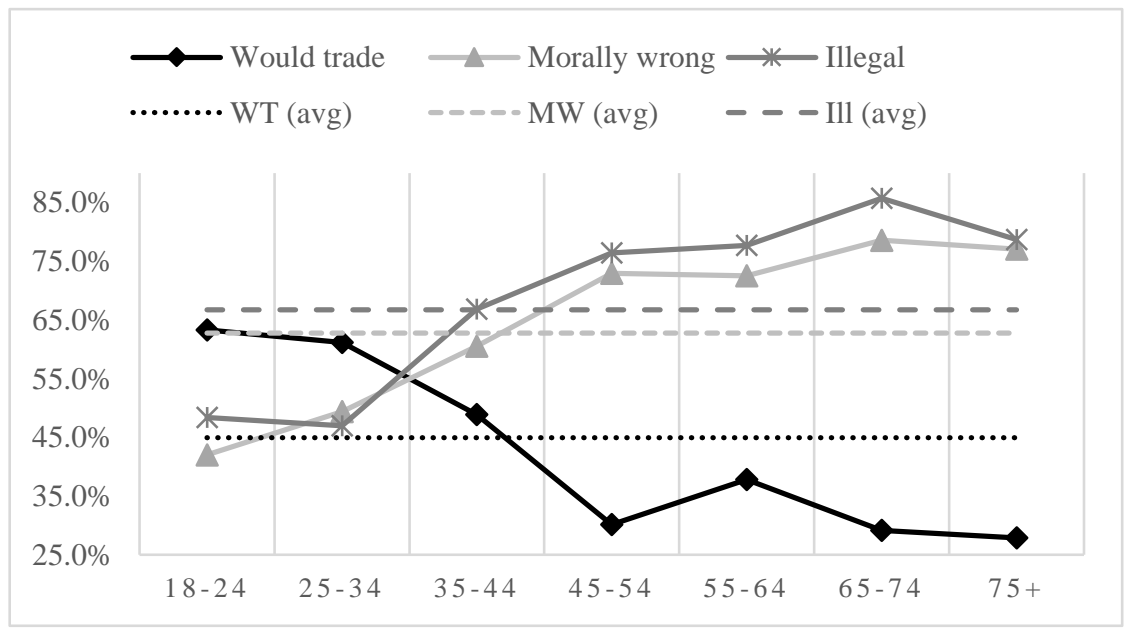

As income and education rise, tolerance for insider trading declines, as shown in Figures 6 and 7. Higher income is correlated with the beliefs that insider trading is morally wrong and should be illegal and inversely correlated with willingness to trade on inside information. Education shows similar, but weaker, correlations, with the least educated tending to be more tolerant of insider trading and the most educated less tolerant.

271 See supra text accompanying note 255; infra Section IV.E.2.

272 Peter Bossaerts \& Carsten Murawski, Decision Neuroscience: Why We Become More Cautious with Age, 26 Current Bio. 1634 (2016); Libby Kane, Young People Are Risky Investors-And It Isn't Paying Off, Bus. Insider (Dec. 19, 2014), https://www.businessinsider.com/young-people-risky-investors-2014-12. 
Figure 6: Acceptance of Insider Trading by Income

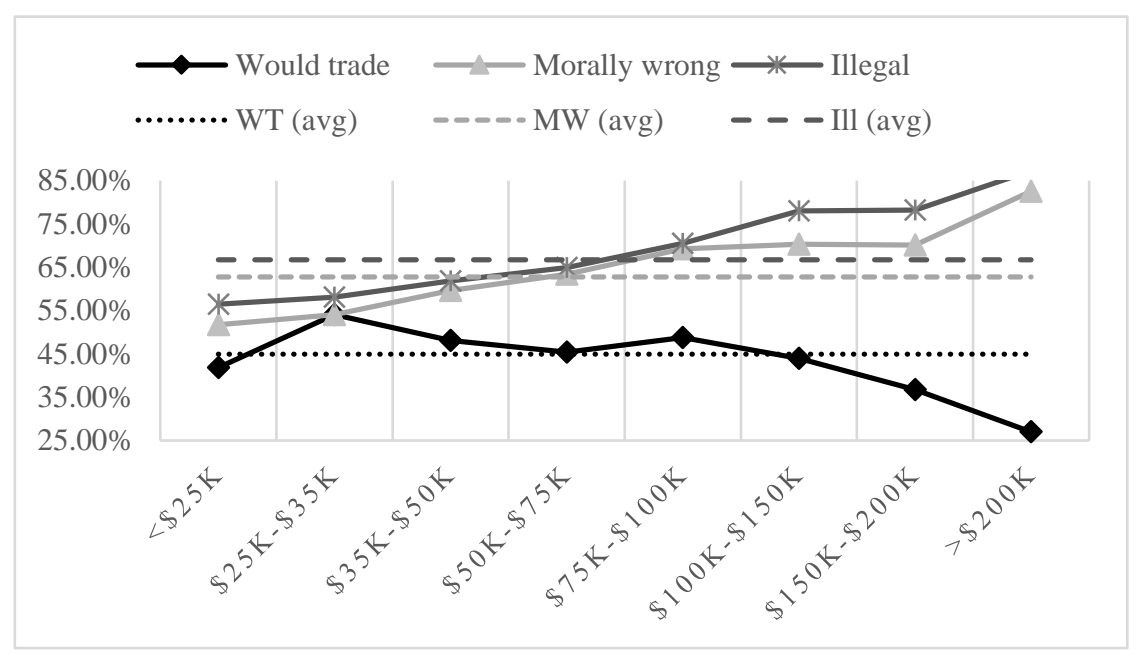

Figure 7: Acceptance of Insider Trading by Education

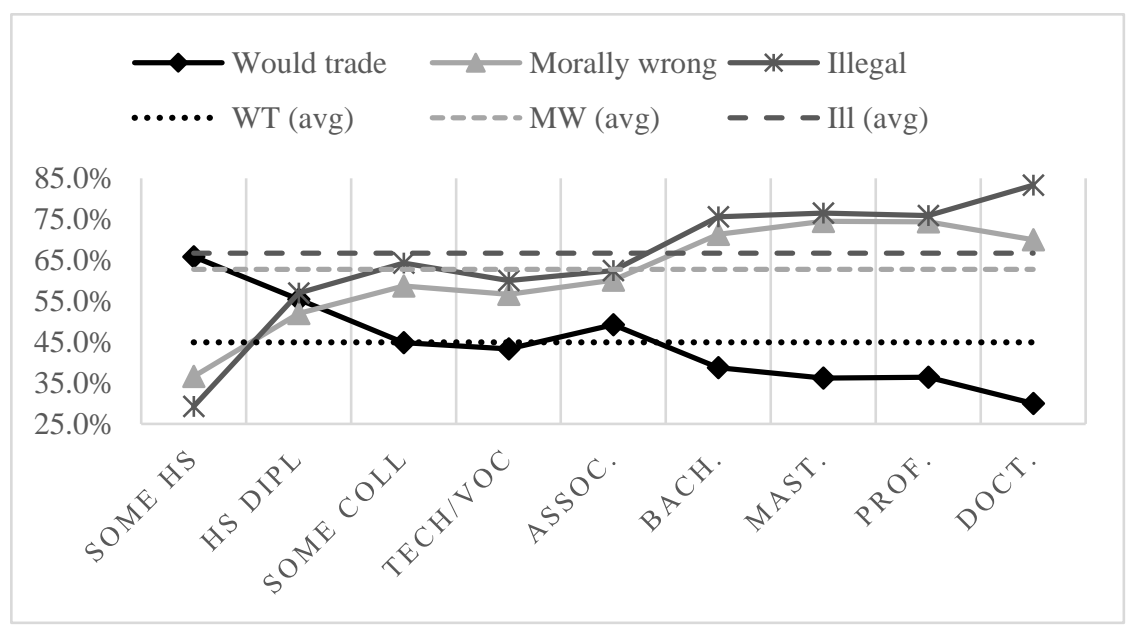

Perceived or actual financial need may influence these opinions. The less wealthy, who tend to be less educated, ${ }^{273}$ may believe that they do not have the luxury to look down on what the more affluent may view as a distasteful activity. 
A slight majority of active investors indicated a willingness to trade based on inside information if given the opportunity. But they were also noticeably more likely than average to say that insider trading was morally wrong and should be illegal.274

\section{Revealed Moral Positions}

Summary statistics of stated preferences tell only a partial story, serving as a starting point for further analysis. Drilling down into individual participants' answers revealed potential inconsistencies among a substantial number of respondents' answers. Analyzing these inconsistencies may yield more accurate insights into respondents' true moral aversions to insider trading than do their directly expressed preferences.

\section{i. Morality via Pragmatism}

Many respondents' answers suggested that, as a practical matter, their actions would not correspond to their ethical beliefs. At the individual response level, 18.1 percent of participants who stated that insider trading was immoral also indicated that they would nevertheless trade on the basis of inside information. ${ }^{275}$ This group appears to lack firm moral clarity. Table 8 shows that 9.9 percent of respondents indicated that they did not believe insider trading to be unethical but would nonetheless abstain from trading on the basis of inside information. This group appears to be cautious in its trading, presumably abstaining for fear of legal penalties.

Starting with the respondents who describe insider trading as morally wrong and subtracting from that group those who also indicated that they would trade on the basis of inside information-those who exhibit moral disclarity-yields those respondents who are most certain that insider trading is unethical. Similarly, beginning with the number of respondents who decline to trade on inside information and subtracting those who indicated that their abstention was not based on moral grounds-the cautious abstainers-yields those scrupulous abstainers who would not trade on the basis of inside information because they truly believe that it is immoral.

274 Recall, however, that fewer than half of active traders said that they would be less likely to trade knowing that insider trading was pervasive. See supra Table 4.

275 Similar results were observed in the scenario-based assessment of insider trading views. See supra Section III.B.2. Compare infra Figure 10 and Figure 11, with infra Figure 12 and Figure 14. 
Table 7 shows, at the summary level, participants' answers to whether they would trade based on inside information and whether insider trading was morally wrong. Table 8 shows the percentages of survey participants who exhibited moral disclarity, cautious abstention from trading, and, importantly, the percentages of respondents who exhibited moral certainty that insider trading is wrong and of those who would scrupulously abstain from insider trading because of their authentic belief that it should be illegal.

Table 8: Practicality Versus Morality

\begin{tabular}{|c|c|c|c|c|}
\hline & $\begin{array}{l}\text { Moral } \\
\text { Disclarity }^{276}\end{array}$ & $\begin{array}{l}\text { Cautious } \\
\text { Abstention }^{277}\end{array}$ & $\begin{array}{l}\text { Moral } \\
\text { Certainty } \\
278\end{array}$ & $\begin{array}{l}\text { Scrupulous } \\
\text { Abstention }^{279}\end{array}$ \\
\hline Overall & $18.1 \%$ & $9.9 \%$ & $44.7 \%$ & $45.2 \%$ \\
\hline \multicolumn{5}{|l|}{ Gender } \\
\hline Female & $16.3 \%$ & $10.9 \%$ & $43.1 \%$ & $43.3 \%$ \\
\hline Male & $20.0 \%$ & $9.0 \%$ & $46.6 \%$ & $47.4 \%$ \\
\hline \multicolumn{5}{|l|}{ Race } \\
\hline Asian & $21.2 \%$ & $9.1 \%$ & $34.9 \%$ & $34.9 \%$ \\
\hline Black & $17.4 \%$ & $14.6 \%$ & $25.8 \%$ & $26.4 \%$ \\
\hline Latinx & $21.7 \%$ & $14.5 \%$ & $24.1 \%$ & $24.1 \%$ \\
\hline Native Am. & $25.0 \%$ & $0.0 \%$ & $33.3 \%$ & $33.3 \%$ \\
\hline White & $17.7 \%$ & $8.9 \%$ & $50.8 \%$ & $51.4 \%$ \\
\hline Other & $9.1 \%$ & $9.1 \%$ & $50.0 \%$ & $50.0 \%$ \\
\hline \multicolumn{5}{|c|}{ Trading Status } \\
\hline Invest & $23.0 \%$ & $4.6 \%$ & $43.5 \%$ & $44.0 \%$ \\
\hline Abstain & $14.2 \%$ & $14.2 \%$ & $45.1 \%$ & $45.5 \%$ \\
\hline
\end{tabular}

276 The percentage of respondents who would trade based on inside information despite stating that they believed that insider trading is morally wrong.

277 The percentage of respondents who would not trade based on inside information despite stating that they believed that insider trading is not morally wrong.

278 This number is arrived at by starting with the number of respondents who state that they believe that insider trading is morally wrong, see supra Table 7, and subtracting those evincing moral disclarity (i.e., those who would trade based on inside information despite stating that insider trading is morally wrong), see supra note 276 and accompanying text.

279 This number is arrived at by starting with the number of respondents who refuse to trade based on inside information, see supra Table 1, and subtracting those who do so only because it is illegal, see supra note 277 and accompanying text. 
Moral certainty and scrupulous abstention are implicit measures of moral aversion to insider trading. They are remarkably consistent within socioeconomic cohorts. A few outliers notwithstanding, most cohorts exhibit little to no difference between the two measures, as shown in Figure 8. The consistently small differences between these two derived measures suggest that most respondents' stated views overestimate their moral aversion to insider trading. This measure, therefore, provides some evidence that the actual percentage of respondents who believe that insider trading is immoral is likely less than 62.8 percent and could be as low as 44.7 percent.

Figure 8: Moral Certainty Versus Scrupulous Abstention

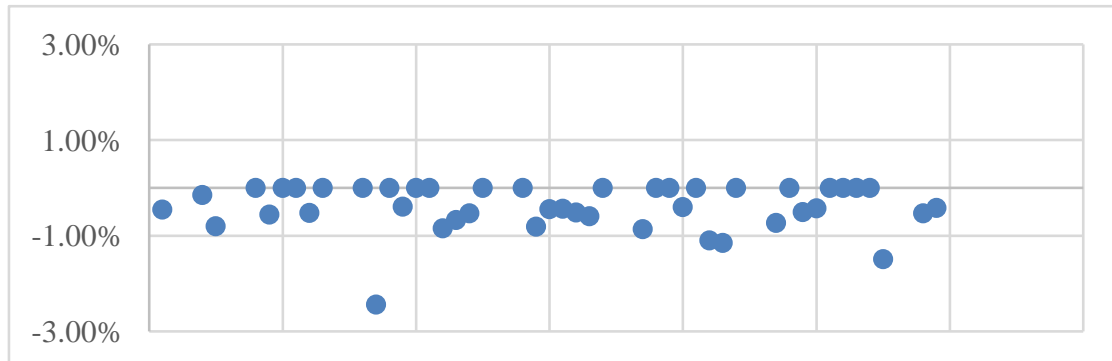

Men were less morally clear and women more cautious. Revealed views by income, education, and age followed patterns similar to those expressed directly, but with a substantially lower absolute magnitude. 280

Among racial groups, Black participants were the most cautious, but also among the least morally unclear. Native American respondents were the most morally unclear and the least cautious. White participants were among the least cautious and only slightly less morally unclear than Black participants.

Active investors' revealed views fell much closer to the overall figures than their stated positions suggested. ${ }^{281}$ 
ii. Morality via Legality

Respondents' views on the morality and legality of insider trading did not track consistently. ${ }^{282}$ As in the previous Section, these data can be used to measure more precisely the public's preference for prohibition. Table 9 shows that 16.0 percent of respondents have complex views on legality and morality. 6.5 percent are permissive, in that, despite believing that insider trading is immoral, they would not make it illegal. But 9.5 percent are strict prohibitionists who would prohibit insider trading even though they do not believe that it is immoral.

Starting with those who believe insider trading is immoral and subtracting from that group those who would not make it illegal yields a group that believes that insider trading is immoral and, therefore, should be banned. Likewise, beginning with those who would like insider trading to be illegal and subtracting those that do not believe the practice to be immoral yields those who say that insider trading should be banned because it is immoral.

If these two derived categories are logically similar, and if they are close to each other in value, they provide greater assurance that they more closely approximate the true percentage of the population that would like to ban insider trading. The final two columns of Table 9 contain these two measures and Figure 9 graphs the difference for each of the demographic cohorts. As in the analysis performed in the previous Section, two outliers notwithstanding, the differential between the two measures is narrow across cohorts. Under this measure, the likely percentage of Americans who believe insider trading should be illegal is between about 56 and 66.3 percent.

Combined with the previous morality-via-pragmatism data, the percentage of participants believing that insider trading is immoral is likely bounded by about 44 percent on the low end and about 56 percent on the high end. That is a substantial slice of society, but potentially less than the 50 percent that the two data points straddle. That, in turn, raises questions about the legitimacy of insider trading laws. ${ }^{283}$

282 This may result partially from the belief that all that is immoral need not be illegal. See supra note 181 . Nevertheless, the differences between expressed moral and practical views is greater than the difference between expressed moral and legal views. Compare supra Table 8: Practicality Versus Morality, with infra Table 9.

283 See supra text accompanying notes 186-90. 
Table 9: Morality Versus Legality

\begin{tabular}{lcccr} 
& $\begin{array}{c}\text { Permissive } 284 \\
\text { Overall }\end{array}$ & $\begin{array}{l}\text { Strict } \\
\text { Prohibitionist }^{285}\end{array}$ & $\begin{array}{l}\text { Immoral }: \\
\text { Ban }^{286}\end{array}$ & \multicolumn{1}{l}{$\begin{array}{l}\text { Ban } \because \\
\text { Immoral } 287\end{array}$} \\
$\begin{array}{l}\text { Gender } \\
\text { Female }\end{array}$ & $6.5 \%$ & $9.5 \%$ & $56.3 \%$ & $57.2 \%$ \\
Male & $6.7 \%$ & $9.4 \%$ & $52.6 \%$ & $53.1 \%$ \\
Race & & $9.8 \%$ & $60.4 \%$ & $61.7 \%$ \\
Asian & $4.6 \%$ & $9.1 \%$ & $51.5 \%$ & $53.0 \%$ \\
Black & $9.6 \%$ & $11.2 \%$ & $33.7 \%$ & $34.3 \%$ \\
Latinx & $9.6 \%$ & $12.1 \%$ & $36.1 \%$ & $36.1 \%$ \\
Native Am. & $8.3 \%$ & $8.3 \%$ & $50.0 \%$ & $50.0 \%$ \\
White & $5.9 \%$ & $9.0 \%$ & $62.7 \%$ & $63.6 \%$ \\
Other & $0.0 \%$ & $13.64 \%$ & $59.1 \%$ & $59.1 \%$ \\
Trading Status & & & & \\
Invest & $7.1 \%$ & $10.5 \%$ & $59.4 \%$ & $60.8 \%$ \\
Abstain & $6.2 \%$ & $8.9 \%$ & $53.1 \%$ & $53.5 \%$
\end{tabular}

284 The percentage of respondents who would not ban insider trading despite stating that they believed that insider trading is morally wrong.

285 The percentage of respondents who would ban insider trading despite stating that they believed that insider trading is not morally wrong.

286 "Immoral Therefore Ban." This number is arrived at by starting with the number of respondents who state that they believe that insider trading is morally wrong, see supra Table 7, and subtracting those evincing permissive views (i.e., those would not ban insider trading despite stating that they believed that insider trading is morally wrong), see supra note 284 and accompanying text.

287 "Ban Because Immoral." This number is arrived at by starting with the number of respondents who state that they would ban insider trading, see supra Table 7: Stated Moral Positions, and subtracting those who evince strict prohibitionist views, see supra note 285 and accompanying text. 
Figure 9: Immoral-Therefore-Ban versus Ban-Because-Immoral288

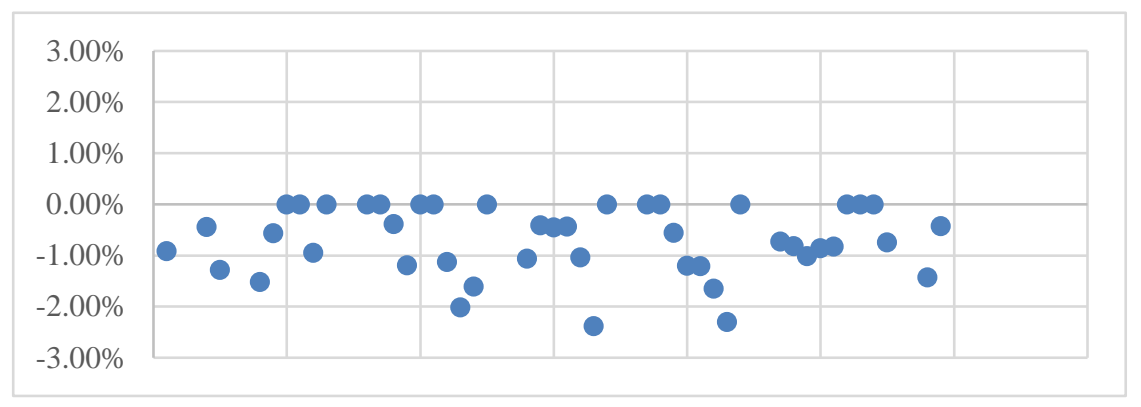

Differences between cohorts were slight. Men were less permissive than women, but well within the margin of error. Asian and White participants were less likely, and Black and Latinx participants more likely, to be permissive. There were no clear trends apparent in the data along age, education, or income lines. Active traders were more likely to believe that insider trading should be banned.

\section{Self-Conscious Punishment Views}

Fear of punishment amid more frequent enforcement actions, increased public chatter about the topic, or both, may explain why only 45 percent of respondents indicated that they would trade based on inside information, as compared with 53 and 55 percent in the 1986 surveys. ${ }^{289}$ If insider trading is to be illegal, violations of the law must, presumably, be punished. Each respondent who indicated that insider trading should be illegal was, therefore, asked to identify the appropriate punishment for a violation of the law.

Participants were first asked what the appropriate punishment should be, in the abstract, for an insider trading violation. Immediately following, they were asked what the punishment should be for themselves, should they be found guilty of insider trading. Respondents could choose between high fines (greater than $\$ 100,000$ ), low fines (less than $\$ 100,000$ ), minor jail time (less than 1 year in prison), or major jail time (more than 1 year in prison). It is generally accepted that fines carry a lesser stigma and are less harmful to their recipients than jail time. ${ }^{290}$

288 In mathematical terms, (Immoral $\therefore$ Ban $) \bumpeq$ (Ban $\because$ Immoral).

289 See supra Table 1.

290 See, e.g., 1 Joel FeinberG, The Moral Limits of Criminal Law 2, 20 (1987). 
The survey presented the two questions in sequence, which would ordinarily reduce any disparity between the two responses because people generally try to avoid obvious self-contradiction.291 Nevertheless, respondents differed significantly in what they believed would be an appropriate punishment, largely in the direction of their being more lenient with themselves than with others who were caught insider trading. Table 10 shows the percentages of respondents who chose high and low fines as the proper punishment in the abstract, high and low fines for themselves, and the change vis-à-vis jail time for themselves versus in the abstract.

291 See 1 David L. Faigman et al., Modern Scientific Evidence: The Law and Science of EXPERT TESTIMONY $\S 7: 20$ (database updated Nov. 2019) (noting that, as here, question-order effects are minimized if general questions precede specific ones); Jon A. Krosnick \& Stanley Presser, Question and Questionnaire Design, in HaNDBook OF SuRveY RESEARCH 264, 280 (Peter V. Marsden \& James D. Wright eds., 2d ed. 2010) (same). 
Table 10: Fines for Thee Versus Fines for $M e^{292}$

\begin{tabular}{|c|c|c|c|c|c|c|c|c|c|}
\hline & \multicolumn{3}{|c|}{$\begin{array}{l}\text { Just Punishment for } \\
\text { Abstract Insider } \\
\text { Trading }\end{array}$} & \multicolumn{3}{|c|}{$\begin{array}{l}\text { Just Punishment } \\
\text { for My Insider } \\
\text { Trading }\end{array}$} & \multicolumn{2}{|c|}{ Change $^{293}$} & \multirow[b]{2}{*}{ Net } \\
\hline & $\mathbf{L F}$ & HF & Total & LF & HF & Total & LF & HF & \\
\hline Overall & $18.6 \%$ & $32.5 \%$ & $51.1 \%$ & $26.3 \%$ & $30.8 \%$ & $57.1 \%$ & $7.7 \%$ & $-1.7 \%$ & $5.9 \%$ \\
\hline \multicolumn{10}{|l|}{ Gender } \\
\hline Female & $22.1 \%$ & $35.0 \%$ & $57.0 \%$ & $28.7 \%$ & $34.3 \%$ & $62.9 \%$ & $6.6 \%$ & $-0.7 \%$ & $5.9 \%$ \\
\hline Male & $15.3 \%$ & $30.3 \%$ & $45.5 \%$ & $23.8 \%$ & $27.8 \%$ & $51.6 \%$ & $8.5 \%$ & $-2.5 \%$ & $6.0 \%$ \\
\hline \multicolumn{10}{|l|}{ Race } \\
\hline Asian & $22.0 \%$ & $24.4 \%$ & $46.3 \%$ & $29.3 \%$ & $17.1 \%$ & $46.3 \%$ & $7.3 \%$ & $-7.3 \%$ & $0.0 \%$ \\
\hline Black & $21.0 \%$ & $28.4 \%$ & $48.4 \%$ & $28.4 \%$ & $32.1 \%$ & $60.5 \%$ & $7.4 \%$ & $3.7 \%$ & $11.1 \%$ \\
\hline Latinx & $17.5 \%$ & $32.5 \%$ & $50.0 \%$ & $22.5 \%$ & $40.0 \%$ & $62.5 \%$ & $5.0 \%$ & $7.5 \%$ & $12.5 \%$ \\
\hline Native Am. & $14.3 \%$ & $0.0 \%$ & $14.3 \%$ & $28.6 \%$ & $0.0 \%$ & $28.6 \%$ & $14.3 \%$ & $0.0 \%$ & $14.3 \%$ \\
\hline White & $18.2 \%$ & $33.9 \%$ & $52.1 \%$ & $25.9 \%$ & $31.7 \%$ & $57.6 \%$ & $7.7 \%$ & $-2.2 \%$ & $5.5 \%$ \\
\hline Other & $18.8 \%$ & $31.3 \%$ & $50.0 \%$ & $25.0 \%$ & $18.8 \%$ & $43.8 \%$ & $6.3 \%$ & $-12.5 \%$ & $-5.3 \%$ \\
\hline \multicolumn{10}{|c|}{ Trading Status } \\
\hline Invest & $17.0 \%$ & $31.0 \%$ & $48.0 \%$ & $25.0 \%$ & $30.0 \%$ & $55.0 \%$ & $8.0 \%$ & $-1.0 \%$ & $7.0 \%$ \\
\hline Abstain & $20.1 \%$ & $33.1 \%$ & $53.2 \%$ & $27.3 \%$ & $30.2 \%$ & $57.4 \%$ & $7.2 \%$ & $-2.9 \%$ & $4.3 \%$ \\
\hline
\end{tabular}

Slightly more than half of the participants chose fines as the proper penalty for insider trading in the abstract, with a strong majority of those participants choosing high fines. When asked about the appropriate punishment for themselves, a higher percentage chose fines, with the increase coming in the form of an increased preference for the least severe penalty, lower fines.

Women were more likely to recommend fines in both the abstract and for themselves and were slightly more consistent than men. Native American respondents were substantially less likely to recommend fines in both scenarios.

292 "LF" stands for low fines, "HF" stands for high fines.

293 These columns show the total changes in the percentages of respondents choosing low fines, high fines, and fines generally when selecting the appropriate punishment for themselves versus the appropriate punishment for insider trading in the abstract. An increase (decrease) in the Net column indicates the percentage of respondents who preferred (did not prefer) fines to jail time when they, rather than an abstract individual, were subject to the penalty. 
The highest shifts from jail time to fines were exhibited by Black, Latinx, and Native American respondents along the race dimension; those with some high school along educational lines; those between the ages of 35 and 54; and the very conservative, liberal, and communist by ideology.

Nearly every cohort saw an increase in the preference for fines when faced with how to punish themselves for insider trading; those with doctoral degrees and the very liberal decreased the total preference for fines, preferring prison time. Every cohort, save four that saw no change, ${ }^{294}$ saw an increase in the preference for low fines, indicating that any overall decrease in preference for fines among those two groups was the result of a shift from high fines to jail time. Table 11 shows the percentages of respondents who chose major and minor jail time as the proper punishment in the abstract and for themselves, and the change vis-à-vis jail time for themselves versus in the abstract.

294 Of the cohorts that saw no change, one involved a single participant who indicated no formal education and three participants who did not identify as male or female. 
Table 11: Jail for Thee Versus Jail for $\mathrm{Me}^{295}$

\begin{tabular}{|c|c|c|c|c|c|c|c|c|c|}
\hline & \multicolumn{3}{|c|}{$\begin{array}{l}\text { Just Punishment for } \\
\text { Abstract Insider } \\
\text { Trading }\end{array}$} & \multicolumn{3}{|c|}{$\begin{array}{l}\text { Just Punishment } \\
\text { for My Insider } \\
\text { Trading }\end{array}$} & \multicolumn{3}{|c|}{ Change vs. Fines 296} \\
\hline & MiJ & MaJ & Total & MiJ & MaJ & Total & MiJ & MaJ & Net \\
\hline Overall & $20.3 \%$ & $28.0 \%$ & $48.3 \%$ & $16.0 \%$ & $25.6 \%$ & $41.6 \%$ & $-4.3 \%$ & $-2.4 \%$ & $-6.7 \%$ \\
\hline \multicolumn{10}{|l|}{ Gender } \\
\hline Female & $20.0 \%$ & $22.8 \%$ & $42.7 \%$ & $15.0 \%$ & $20.7 \%$ & $35.7 \%$ & $-4.9 \%$ & $-2.1 \%$ & $-7.0 \%$ \\
\hline Male & $20.9 \%$ & $33.0 \%$ & $53.8 \%$ & $17.0 \%$ & $30.3 \%$ & $47.3 \%$ & $-3.8 \%$ & $-2.7 \%$ & $-6.5 \%$ \\
\hline \multicolumn{10}{|l|}{ Race } \\
\hline Asian & $4.9 \%$ & $48.8 \%$ & $53.7 \%$ & $14.6 \%$ & $39.0 \%$ & $53.7 \%$ & $9.8 \%$ & $-9.8 \%$ & $-0.0 \%$ \\
\hline Black & $23.5 \%$ & $27.2 \%$ & $50.6 \%$ & $17.3 \%$ & $19.8 \%$ & $37.0 \%$ & $-6.2 \%$ & $-7.4 \%$ & $-13.6 \%$ \\
\hline Latinx & $27.5 \%$ & $22.5 \%$ & $50.0 \%$ & $17.5 \%$ & $15.0 \%$ & $32.5 \%$ & $-10.0 \%$ & $-7.5 \%$ & $-17.5 \%$ \\
\hline Native Am. & $42.9 \%$ & $42.9 \%$ & $85.7 \%$ & $42.9 \%$ & $28.6 \%$ & $71.4 \%$ & $0.0 \%$ & $-14.3 \%$ & $-14.3 \%$ \\
\hline White & $20.2 \%$ & $27.2 \%$ & $47.4 \%$ & $15.4 \%$ & $26.0 \%$ & $41.4 \%$ & $-4.8 \%$ & $-1.2 \%$ & $-6.0 \%$ \\
\hline Other & $25.0 \%$ & $25.0 \%$ & $50.0 \%$ & $25.0 \%$ & $31.3 \%$ & $56.3 \%$ & $0.0 \%$ & $6.3 \%$ & $6.3 \%$ \\
\hline
\end{tabular}

Trading Status

$\begin{array}{llllllllll}\text { Invest } & 19.5 \% & 32.0 \% & 51.5 \% & 16.0 \% & 27.5 \% & 43.5 \% & -3.5 \% & -4.5 \% & -8.0 \% \\ \text { Abstain } & 21.4 \% & 25.0 \% & 46.4 \% & 16.7 \% & 24.8 \% & 41.4 \% & -4.7 \% & -0.2 \% & -5.0 \%\end{array}$

Fewer than half of respondents chose jail time as the appropriate punishment for insider trading in the abstract. That number declined by 6.7 percent when the punishment was to be inflicted on themselves.

Men had a stronger preference for jail time, though that preference declined by as much as it did for women when the punishment was to be inflicted upon themselves.

295 "MiJ" stands for minor jail time; "MaJ" stands for major jail time.

296 These columns show the total changes in the percentages of respondents choosing minor jail time, major jail time, and jail time generally when selecting the appropriate punishment for themselves versus the appropriate punishment for insider trading in the abstract. An increase (decrease) in the Net column indicates the percentage of respondents who preferred (did not prefer) jail time to fines when they, rather than an abstract individual, were subject to the penalty.

Because some respondents did not answer all questions, the change from jail time to fines, see supra columns accompanying note 293 , and the change from fines to jail time are not mirror images. 
Asian participants, Native American participants, and those earning more than $\$ 75,000$ but less than $\$ 100,000$ preferred jail time as a general punishment and self-punishment. Table 12 shows additional summary statistics.

Table 12: Differences Between Self-Regarding and Other-Regarding Punishment Views

\begin{tabular}{cccccc}
$\begin{array}{c}\text { Total } \\
\text { Change }\end{array}$ & $\begin{array}{c}\text { Fines to } \\
\text { Jail }\end{array}$ & $\begin{array}{c}\text { Jail to } \\
\text { Fines }\end{array}$ & $\begin{array}{c}\text { Harsher } \\
\text { for Self }\end{array}$ & $\begin{array}{c}\text { More Lenient } \\
\text { for Self }\end{array}$ & $\begin{array}{c}\text { Change to } \\
\text { Low Fines }\end{array}$ \\
$31.4 \%$ & $6.7 \%$ & $12.7 \%$ & $8.8 \%$ & $22.6 \%$ & $11.2 \%$ \\
\hline LF to HF & LF to MaJ & LF to MiJ & HF to LF & HF to Maj & HF to MiJ \\
$2.1 \%$ & $0.3 \%$ & $1.3 \%$ & $5.1 \%$ & $2.6 \%$ & $2.5 \%$ \\
\hline & & & & & \\
MiJ to HF & MiJ to LF & MiJ to MaJ & MaJ to HF & MaJ to LF & MaJ to MiJ \\
$4.0 \%$ & $3.5 \%$ & $2.5 \%$ & $2.6 \%$ & $2.5 \%$ & $2.3 \%$
\end{tabular}

When confronted with the possibility that they might suffer the punishment, 31.4 percent of respondents changed their answers. More than twice as many participants chose a more lenient punishment for themselves. Almost half of those switching to a more lenient penalty switched to low fines, the least severe punishment.

Punishments should not, of course, be based solely on what individuals would choose for themselves. But the analysis does inform the coherence of public views about insider trading. The significant disparity between what participants choose for others and what they choose for themselves suggests moral ambiguity regarding appropriate punishment for these crimes.

Public opinions about the morality of and appropriate punishment for insider trading appear unstable. Because public intuition about the blameworthiness of criminalized conduct is so important, this instability counsels that insider trading law and policy be carefully considered.

\section{E. Fiduciary Instincts and Propaganda}

The survey's next stage had two important goals. First, it attempted to measure more precisely moral and pragmatic views on insider trading. Respondents were asked to imagine themselves in the shoes of various individuals in possession of material nonpublic 
information in various situations. Each of the five scenarios implicated a different potential fiduciary responsibility. ${ }^{297}$ Second, the survey sought to discern the firmness of the views expressed in the scenarios. The survey presented participants with brief statements extolling the harmfulness, irrelevance, or virtue of insider trading-the propaganda-followed by three follow-up scenarios analogous to three of the five original scenarios. ${ }^{298}$ Section III.B.2, supra, details the varying paths through this portion of the survey.

The next Section describes respondents' expressed fiduciary views based on their pre-propaganda answers to questions in the ethical and pragmatic tracks composing this portion of the survey. The one after that describes the effect of propaganda on survey participants' followup answers.

\section{Revealed Fiduciary Views}

Allowing survey participants to express their views indirectly via scenario-based questions provided a glimpse into their thought processes that direct questioning could not. The key findings are presented here. ${ }^{299}$

\section{i. Ethical Track}

Figures 10 through 12 show the percentages of the ethics cohort indicating that it would be ethical to trade on nonpublic information in each of the various scenarios. Each figure compares either the answers provided in two of the ethical subtracks or the answers provided for the small and large corporations. Figure 10 shows the effect of reversing the order in which respondents heard the scenarios. It is well known that the order in which questions are asked can affect the responses, 300 and that was true here. It was anticipated that participants might answer differently when hearing the most obvious case of insider trading-the CEO-or the least obvious-the quasi-stranger-first. Hearing the CEO example first, for example, may have primed respondents to distrust the following scenarios, even as the scenarios drifted further from the obvious case. Instead, the opposite occurred:

297 As opposed to a fiduciary duty. Not all scenarios presented situations in which trading would have been illegal. The goal was to learn respondents' feelings about each situation.

298 See supra notes 203-04 and accompanying text; Figure 1. Appendix A, available at http://dx.doi.org/10.15786/20.500.11919/7122, contains the text of the questions in each of the four subtracks.

299 The complete result set is available in Appendix B.

300 See supra note 291. 
those who began with the neighbor scenario were more likely to find every succeeding scenario more ethically problematic.

Figure 10: Effect of Reversing Ethical Track Scenario Presentation Order

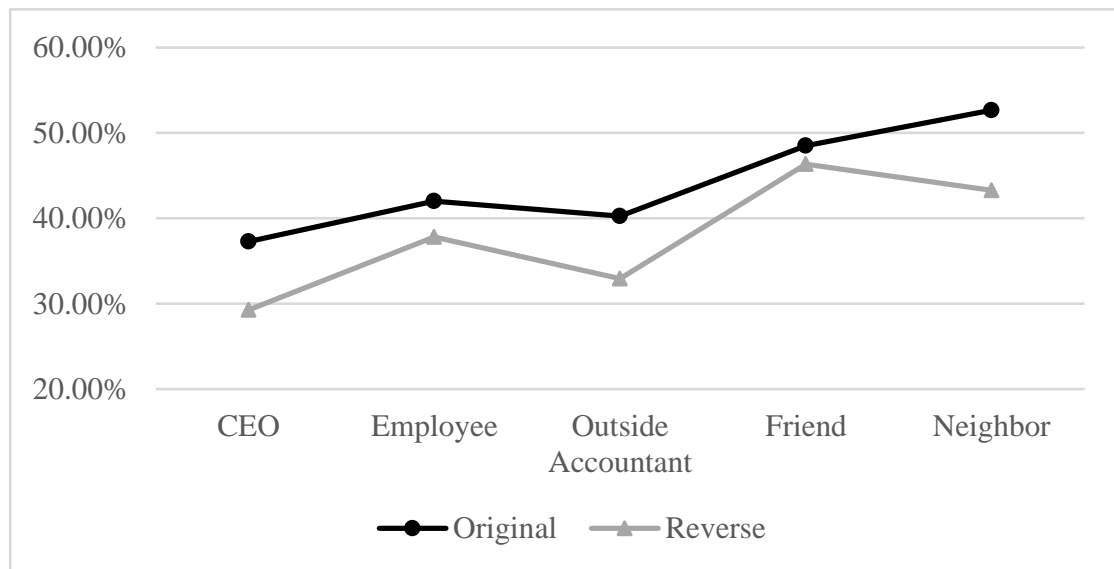

One explanation for this phenomenon is that respondents may have never considered a quasi-stranger insider trading scenario. Understanding that the survey was about insider trading, they may have been primed to consider any scenario as ethically questionable. The anchor ${ }^{301}$ for the reverse cohort may therefore have applied to the least problematic scenario, with every successive scenario progressing into more problematic territory. If this is correct, it may be evidence that participants initially outsourced their views about insider trading, 302 but were willing to adjust those views when presented with nuanced situations eliciting critical thinking. Nevertheless, the trend shows that the more clearly an insider someone was, the less acceptable insider trading was thought to be. Figure 11 shows the contrast between respondents' ethical views about trading in the stock of the smaller corporation, with which they had a relationship ranging from direct to tangential, and about trading in the stock of the larger corporation, with which they had no relationship under the scenarios.

301 See Amos Tversky \& Daniel Kahneman, Judgment Under Uncertainty: Heuristics and Biases, SCIENCE, Sept. 27, 1974, at 1124 (describing the anchoring heuristic, under which individuals tend to depend heavily on the initial piece of information that they receive about a topic).

302 See supra text accompanying note 216. 
Figure 11: Differences in Ethical Views Between the Related and Unrelated Company

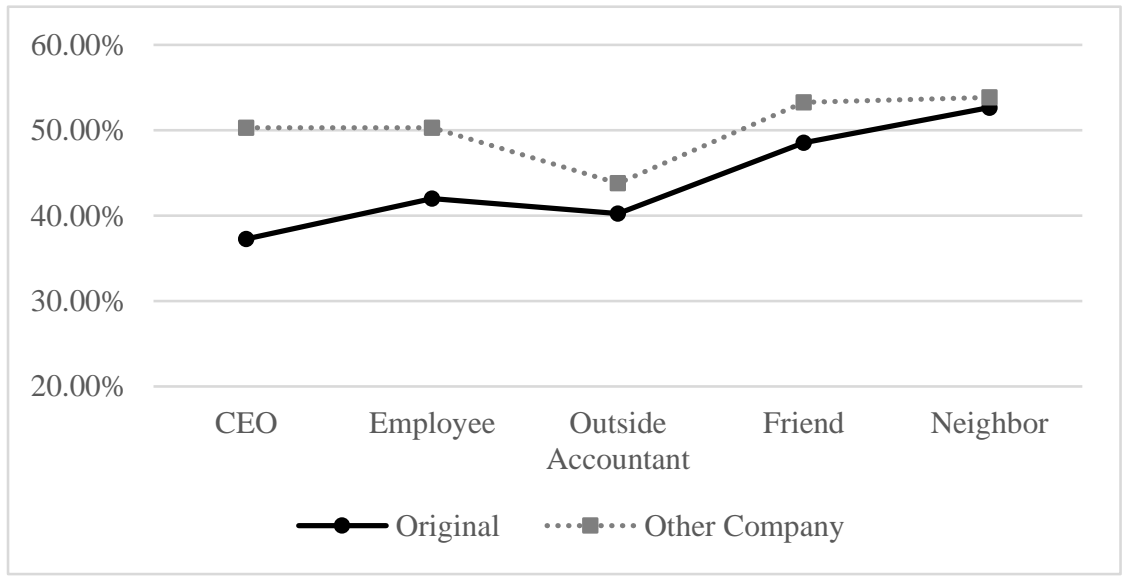

Respondents were more likely to find it acceptable to trade in the stock of the unrelated, larger, corporation. The shrinking differential between the two subtracks tracks a shrinking personal connection to the small company.

Recall that under the classical theory, the harm of insider trading is said to stem from an insider's breach of a duty to current or prospective shareholder-counterparties. ${ }^{303}$ Under the misappropriation theory, the harm of insider trading is a betrayal of the insider's duties to the source (in this case, the small company) of the information. ${ }^{304}$ Trading in the small company's shares thus implicates both the classical and misappropriation theories of liability, at least for the CEO, employee, and outside accountant. ${ }^{305}$ Trading in the other, large company's stock in the same three scenarios implicates only the misappropriation theory.

303 ANDERSON, supra note 17 , at 37-39.

304 Id. at 47.

305 The friend small-company scenario might fall under the classical theory based on tippee liability, or an expansive view of misappropriation liability. The neighbor small-company scenario could not fall under either form of liability. Neither large-company scenario could fall under classical liability. The friend large-company scenario might fall under an expansive view of misappropriation liability, but the neighbor large-company scenario would not.

Views about both the friend and neighbor scenarios, however, are likely influenced by social norms that resemble the misappropriation theory. That is, respondents may have viewed negatively acting on information from an intoxicated friend or an unknowing neighbor in an elevator. 
The consistent differences in attitudes between trading in the small and large companies (by the CEO, employee, and accountant) suggest that there were some respondents whose intuitions aligned with either the classical theory or the misappropriation theory, but not both. If all respondents found the classical and misappropriation theories equally compelling, one would not expect these differences. The survey did not instruct respondents on the nature of any theories of insider trading.

Figure 12 shows the contrast between the original subtrack and the one that was told that the small corporation officially and expressly permitted insiders ${ }^{306}$ to trade on material nonpublic information. It was anticipated that participants' ethical qualms about insider trading would be reduced when they were told that permission had been given.

Figure 12: Effect of Granting the CEO Permission to Trade

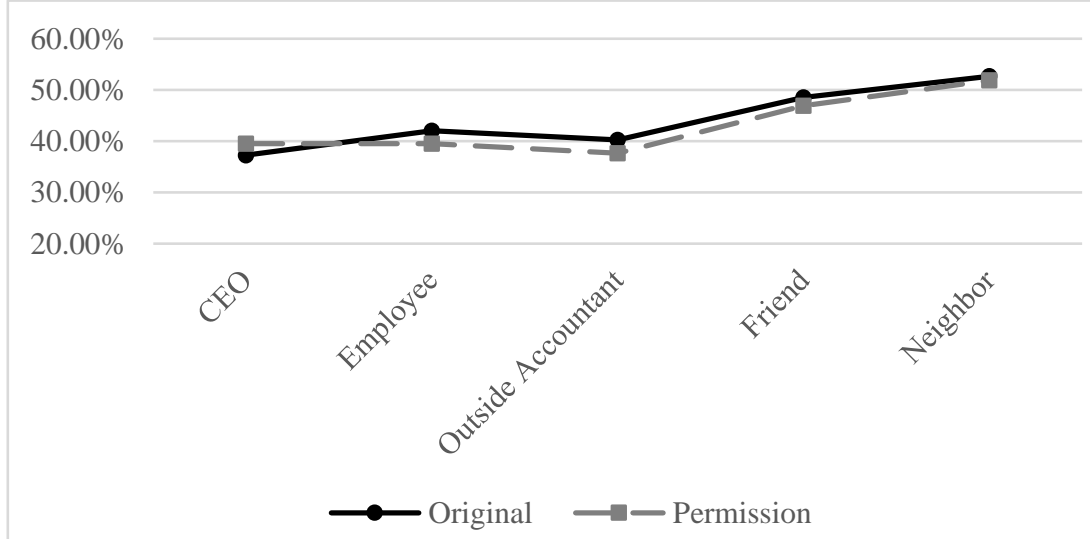

There was a slight increase in the affirmative response in the CEO scenario, but within the margin of error. This part of the survey provided only marginal evidence of an intuitive foundation for the misappropriation theory. Under that theory, the owner of the material nonpublic information could, theoretically, grant permission to insiders and others to use it, in which case it would not be a violation of the trader's duty and, therefore, not be illegal. ${ }^{307}$ The same can be said of

306 "Your corporation has officially granted officers, directors, and employees, including you, permission to trade on inside information" was added to the scenario asking the respondent to assume the role of the firm's CEO. The other questions in the series of scenarios did not contain the addition. See Appendix A.

307 See, e.g., United States v. O'Hagan, 521 U.S. 642, 689 n.5 (1997) (Thomas, J., concurring in part) (noting that the government had conceded that "if [the defendant in Carpenter] had gone to the Wall Street Journal and said ... you're not paying me very much. I'd like to make a little bit more money by buying stock, the stocks that are going to appear in my Heard on the Street column, and the Wall Street Journal said, that's fine, there would have been no [Section 10(b)] deception."). 
the proposed issuer-licensing approach to insider trading, under which trading is allowed by insiders if it is explicitly authorized by the corporation. ${ }^{308}$

Similar questions were asked of the pragmatic track, discussed next.

\section{ii. Pragmatic Track}

Respondents in the pragmatic track were straightforwardly asked whether they would trade in the various scenarios. The goal was to isolate the impact of the fear of legal consequences on the willingness to insider trade, without reference to the transactions' ethics. One might expect less change between items compared in the pragmatic track because it was supposed to be about pragmatism rather than morals. Question ordering, anchoring effects, and so forth should have had less impact on someone concerned solely with pragmatics. This effect, while present, appeared not to completely displace respondents' ethical considerations. Stated differently, ethical considerations are necessary elements of pragmatic decisions. ${ }^{309}$ Making money by trading on material nonpublic information may not be worth it if it makes one feel bad about oneself.

Another factor, perceived reliability of the nonpublic information, seemingly influenced pragmatic decisions. The further the source was from oneself, the less reliable the information, and the less likely someone concerned with pragmatics would be to trade on it.

Figures 13 through 16 show the percentages of the pragmatic cohort indicating that they would trade on nonpublic information in each of the various scenarios. Each Figure compares either the answers provided in two of the ethical subtracks or the answers provided for the small and large corporations. Figure 13 shows a similar anchoring effect of reversing scenario order as in the ethical track, ${ }^{310}$ although the difference disappears in the neighbor scenario, in which pragmatic-track respondents were less likely to say that they would trade on inside information.

\footnotetext{
308 ANDERSON, supra note 17, at 243-46.

309 See Adam Smith, The Theory of Moral Sentiments 194 (11th ed. 1812) ("Man naturally desires, not only to be loved, but to be lovely.").

310 See supra note 301 and surrounding text.
} 
Figure 13: Effect of Reversing Pragmatic-Track Scenario Presentation Order

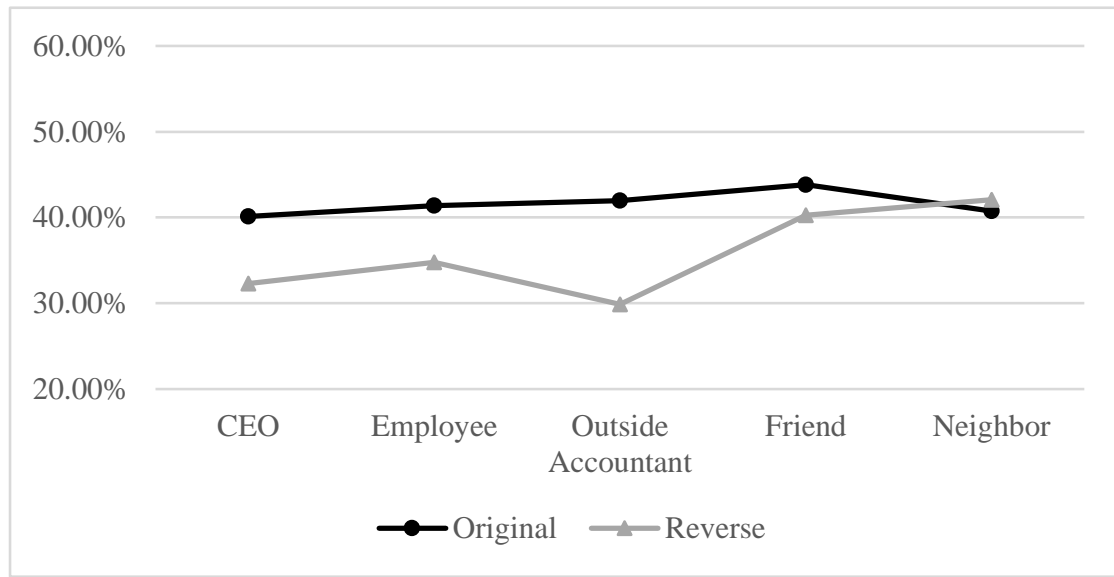

In the original scenario, participants started at roughly the same point as in the corresponding ethical scenario. ${ }^{311}$ As they moved through the subtrack, however, their responses stayed flatter, not rising as high as in the ethical one. ${ }^{312}$ This may indicate that they were focusing on pragmatics, as was the goal of this track, and were less willing to trade because they saw the information sources as progressively less reliable. Nevertheless, there was an upward trend in the data, potentially suggesting, especially when combined with other findings in this section, that ethical considerations seeped into participants' analyses. ${ }^{313}$

In the reverse subtrack, respondents also started at roughly the same point and the change in their responses was again flatter than in the corresponding ethical scenario, but the effect was less pronounced. ${ }^{314}$ Figure 14 shows the contrast between respondents' willingness to trade in the stock of the smaller corporation and that of the larger corporation. As in the previous comparison, the difference was smaller in the pragmatic track than the ethical track,315 and the contrast fades in the later scenarios.

\footnotetext{
311 See supra Figure 10.

312 Id.

313 See infra text accompanying note 317; supra note 309 and accompanying text.

314 See supra Figure 10.

315 See supra Figure 11.
} 
Figure 14: Differences in Pragmatic Actions Between the Related and Unrelated Company

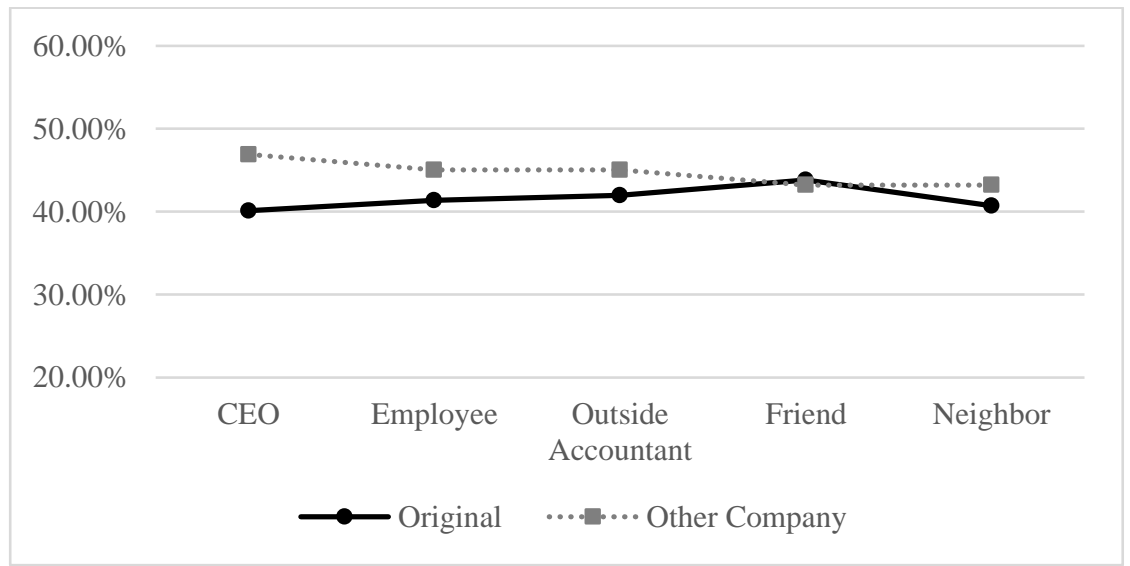

Respondents may, again, have been more reluctant to trust the profitability of information that was further removed from a reliable source. This includes the possibility that information about the larger company may have been viewed as less reliable because it was further removed from the information's source, who was connected to the smaller company. The combination of these two greater separations (between the source and the respondent, and the source and potential target) may explain why there is no meaningful difference between willingness to invest in the small and large firm in the later scenarios.

Figure 15 shows the contrast between the subtrack whose respondents were told that they could trade "without getting caught" and the one that did not receive that additional instruction. ${ }^{316}$ One would expect, ex ante, that reminding respondents they could trade without getting caught would lower their assessments of the cost of trading on inside information. That, in turn, should have increased the net benefit of insider trading and led to an increase in willingness to trade. Instead, the group that was told it could trade without getting caught showed a lower willingness to trade on inside information in every situation but the neighbor scenario.

316 Appendix A, at 13-17, 25-26. 
Figure 15: Effect of Removing "Without Getting Caught" from the Scenario Description

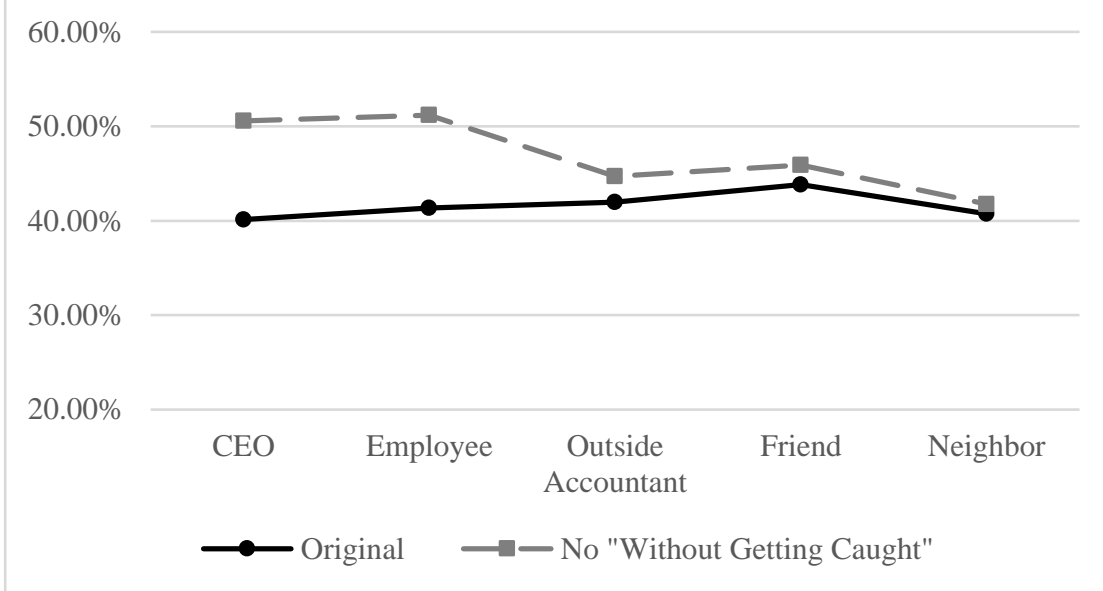

Those who were told that they could trade without getting caught may have been primed to think of insider trading as morally wrong. Instead of reducing the cost of insider trading, the instruction increased its moral salience, and thus the costs of engaging in it. Ethical considerations, in other words, appear to have been transformed into pragmatic ones via respondents' consciences. ${ }^{317}$ Participants in the without-getting-caught subtrack exhibited a clear decline in willingness to trade in both the small and large corporations as the scenarios progressed, as Figure 16 shows. This again suggests that participants viewed the information in the later scenarios as less reliable.

317 See supra note 309 and accompanying text; text accompanying note 313. 
Figure 16: Differences Between the Related and Unrelated Company when "Without Getting Caught" Is Removed from the Scenario

Description

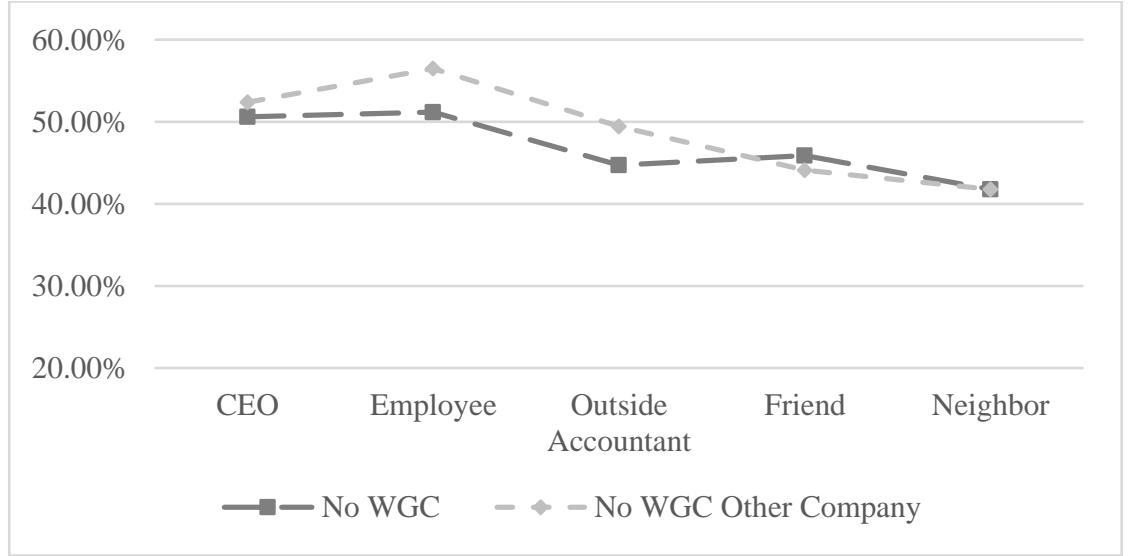

\section{Propaganda is Effective}

The written-and-spoken expositions presenting positive, neutral, or negative effects of insider trading 318 had both obvious and less-obvious effects on study participants' willingness to countenance trading on material nonpublic information, as well as their willingness to engage in it. Figure 17 contrasts the pre- and post-propaganda answers of the original ethical track. After having been exposed to the propaganda, respondents were increasingly willing to condone insider trading in the CEO scenario but less willing in the Outside Accountant scenario.

Figure 17: Effect of Propaganda on the Ethical Track

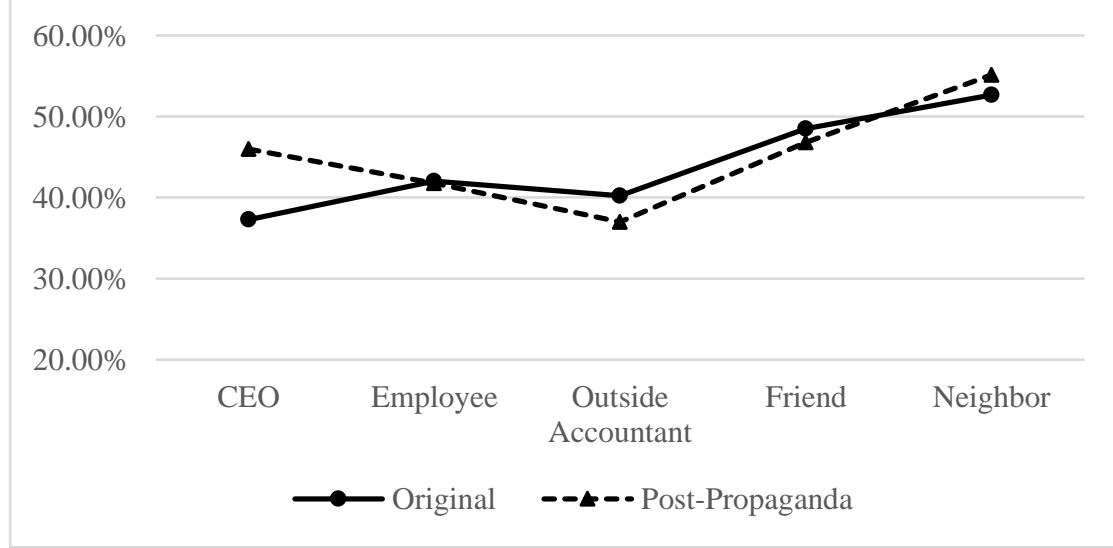

318 See supra notes 203-204, 298 and accompanying text; Figure 1. 
The effect is also present in Figure 18, which shows the contrast between the pre- and post-propaganda answers of the subtrack that was told, in the CEO scenario, that the small corporation granted permission to employees to trade on inside information. After exposure to propaganda, participants exhibited a reduced willingness to condone insider trading in the Employee and Outside Accountant scenarios.

Figure 18: Effect of Propaganda on the Ethical Track with Permission to Trade Given in CEO Scenario

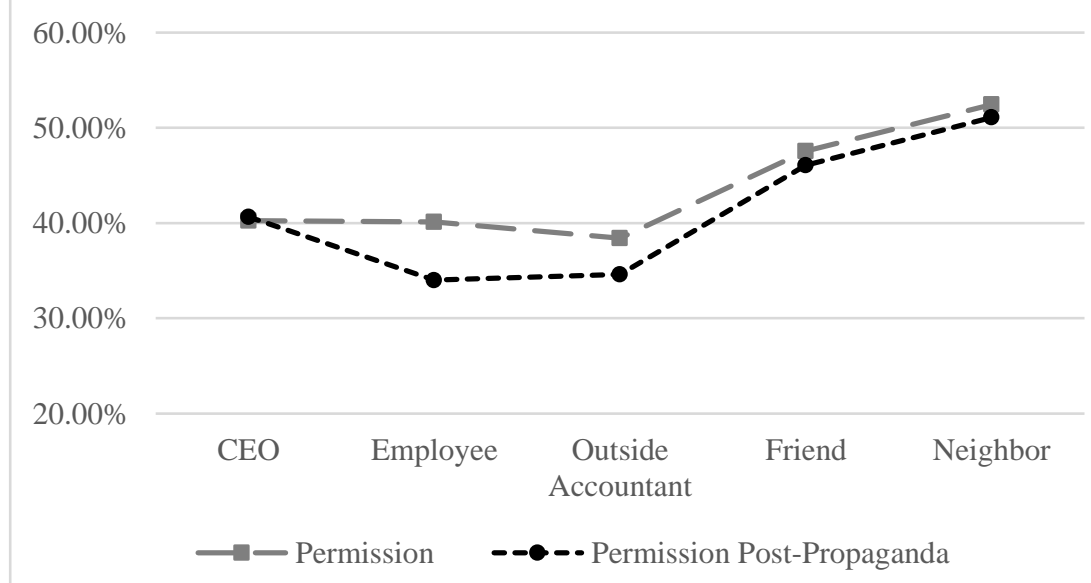

Figures 19 and 20 show the impact of propaganda on the original pragmatic subtrack and on the subtrack that was not told that it could trade "without getting caught." In the original pragmatic subtrack, exposure to propaganda led to a decreased willingness to engage in insider trading in the Outside Accountant scenario. For participants who were not told they could trade without getting caught, exposure to propaganda led to a decreased willingness to engage in insider trading in CEO and Outside Accountant scenarios. 
Figure 19: Effect of Propaganda on the Pragmatic Track

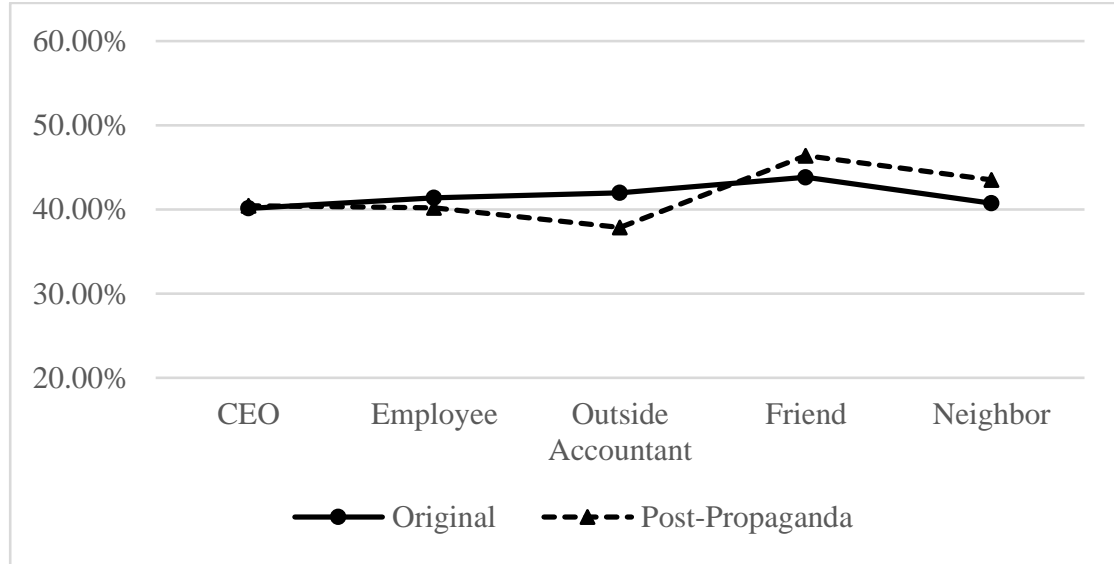

Figure 20: Effect of Propaganda on the Pragmatic-Track Group Told That It Could Trade "Without Getting Caught"

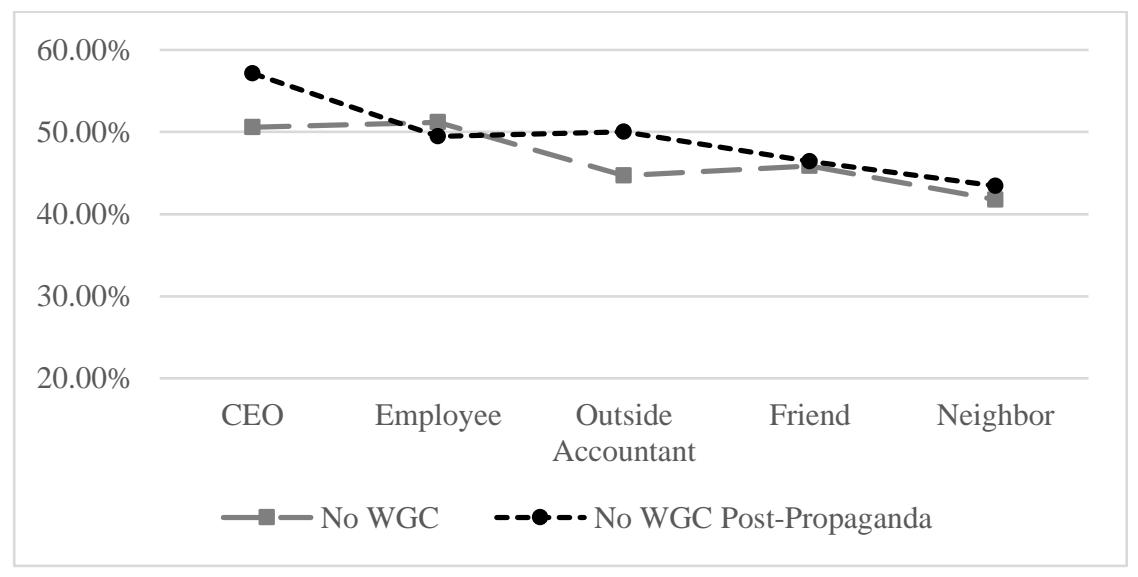

The effect of propaganda in these scenarios is a net effect, and participants were equally likely to be exposed to pro-trading, neutral, and anti-trading propaganda. The expected net effect should therefore be zero, and nonzero effects are evidence that participants' views on insider trading are susceptible to change and may not be firmly held.

Further evidence is provided by Table 13, which identifies the percentage of respondents who changed their responses post-propaganda. It includes both those who became more permissive or more willing and those who became less so. The study did not track which piece of propaganda was presented to each participant because the goal was not to identify the efficacy of a given type (pro-restriction, 
neutral, pro-trading) of propaganda, but rather to gauge whether public views on the ethics and pragmatics of insider trading were firmly held.

Table 13: Post-Propaganda Change of Opinion

(Own Corporation Only) 319

Ethical Path

No Explicit Permission

CEO

$29.0 \%$

Employee

$21.4 \%$

Accountant

$26.0 \%$

Friend

$17.0 \%$

Neighbor

Explicit Permission for CEO

CEO

$26.4 \%$

Employee

$21.7 \%$

Accountant

$23.1 \%$

Friend

$19.6 \%$

Neighbor

$15.2 \%$

Pragmatic Path

"Without Getting Caught"

CEO

$17.0 \%$

Employee

$14.0 \%$

Accountant

$16.5 \%$

Friend

$9.3 \%$

Neighbor

$8.2 \%$

No "Without Getting Caught"

CEO

$25.5 \%$

Employee

$17.2 \%$

Accountant

$20.4 \%$

Friend

$18.9 \%$

Neighbor

319 See supra text accompanying note 204. 
In four cases, more than a quarter of participants were swayed by the propaganda, and greater than a tenth were swayed in all but two scenarios. Propaganda was most influential in the CEO scenario, the one most clearly a violation of insider trading laws as currently enforced. The CEO scenario is perhaps the most salient to the public discussion, reinforcing that the public's views of insider trading are not fixed. Respondents' views appear to be less firm than public chatter (which is also propaganda, in effect, if not intent) would suggest.

It may be, as Professor Jeffrey Wagner noted, that "the 'propaganda' generated elastic responses . . . because insider trading . . . is not straightforward for the median voter to grasp. . . and the pro/neutral/con scenarios provided by the survey [we]re probably more detail[ed] and nuance[d] than most survey respondents ha[d] ever considered."320

\section{Instincts About the Nature of Information}

The survey consistently illumined respondents' instincts that inside information belonged to its source. ${ }^{321}$ Table 14 provides a second, individual-response-level look at respondents' moral acceptance of trading, and willingness to trade, in the stock of each company in the ethical and pragmatic tracks. It shows (1) the percentage of respondents who were willing to trade only in the stock of the smaller company with which they had at least a tangential relationship and (2) the same percentages for the stock of the larger corporation. ${ }^{322}$

320 Wagner, supra note 214.

321 See supra text accompanying Figure 10, Figure 11, and Figure 12.

322 Figure 11 and Figure 14 show aggregate data for the ethical and pragmatic tracks. 
Table 14: Acceptance or Willingness to Trade in Own vs. Other Company

\section{Only Own Corporation Only Other Corporation}

Ethical Path

No Explicit Permission

CEO

Employee

Accountant

Friend

Neighbor

Explicit Permission for CEO

CEO

Employee

Accountant

Friend

Neighbor

Pragmatic Path

"Without Getting Caught"

CEO

Employee

Accountant

Friend

Neighbor

No "Without Getting Caught"

CEO

Employee

Accountant

Friend

Neighbor
$6.5 \%$

$19.5 \%$

$5.9 \%$

$14.2 \%$

$7.7 \%$

$11.2 \%$

$7.1 \%$

$11.8 \%$

$7.1 \%$

$8.3 \%$

$2.5 \%$

$13.0 \%$

$6.8 \%$

$9.9 \%$

$5.6 \%$

$6.8 \%$

$5.6 \%$

$6.8 \%$

$8.6 \%$

$8.6 \%$

$6.2 \%$

$12.9 \%$

$6.2 \%$

$9.4 \%$

$4.1 \%$

7.1\%

$7.4 \%$

7.1\%

$6.2 \%$

$8.2 \%$

$10.0 \%$

$11.8 \%$

$4.7 \%$

$10.0 \%$

$4.7 \%$

$9.4 \%$

7.1\%

$5.3 \%$

$5.9 \%$

$5.9 \%$ 
In most subtracks, respondents were more likely to say that it was acceptable to trade in the larger corporation's stock than in their own. This suggests an intuition that trading on one's own company is betrayal or theft. The results stand out in the CEO scenarios, where the betrayal would be the most profound. Where permission to insider trade was not given, nearly one-fifth of participants indicated an acceptance of, or willingness to trade in, the stock of the other company but not their own. When permission was given, that number was halved, presumably because many respondents who would have traded in the other company's stock anyway now also found it acceptable to trade in their own company's stock. ${ }^{323}$

\section{RESEARCH AGENDA}

As expected, this survey illuminated important areas for further investigation. Four additional studies are therefore planned.

The next study will be a more nuanced and in-depth survey of how and why the public forms its views on insider trading. This study, for example, showed that the public's views on insider trading are not firmly held. The next survey will focus more specifically on the rationales for expressed opinions. What, for example, is it about the diverse American experience that prompts the different attitudes revealed herein? How do public perceptions of insider trading, including the appropriateness of punitive measures, compare with those of other crimes? A more detailed and focused survey instrument could elicit answers to such questions.

This study also offered limited support for the market-confidence theory of insider trading, but arguably not sufficient support to validate market confidence as the principal basis for the current insider trading regime. The third study, therefore, will measure the market-level effects of several large insider trading events, including the publication of important judicial decisions, news of criminal indictments, and SEC prosecutions, to determine their effects on market performance. It will also measure the industry-level and company-specific effects of known insider trading schemes.

Finally, this study focused on a census-representative population, rather than on the opinions of financial professionals. As noted in Section II.B.2, however, much controversy centers on the question of how these professionals react to insider trading in the marketplace. The fourth study will, therefore, comprise a series of surveys and interviews

323 There were, of course, respondents who believed that it was morally permissible to, or who would, trade in the stock of either or neither corporation. 
with the market constituents who would be most directly impacted by any proposed statutory reform. It will collect opinions from stakeholders like market makers, hedge fund managers, securities analysts, issuer representatives, and compliance attorneys. As part of these surveys and interviews, participants will be asked to opine on the likely effects of potential legislative language to reform the insider trading regime.

\section{CONCLUSION}

Efforts to reform America's insider trading regime must be informed by the public's moral intuitions, lest the efforts fail in the long run. Yet pending reform proposals proceed without the benefit of data reflecting actual public attitudes. Others have sounded this warning, but this survey provides the most comprehensive analysis of public opinion to date. It charts a path for future research.

This survey opens the lid on what used to be a black box and reveals a reality that tempers many prior assumptions about insider trading. The study reflects significant public ambivalence about the wrongfulness of insider trading, with opposition concentrated largely among the older, wealthier, and more educated. Public opinion also seems unstable, subject to internal inconsistencies, and easily affected by propaganda. Questions remain, especially about foundational concepts such as the market-confidence theory and the moral bases for the existing theories of liability. Complete answers to these and other questions await further study, but reform efforts must take both the questions and answers seriously. 